\title{
Flora da Bahia: Onagraceae
}

\section{Nelma Xavier Marques de Sousa ${ }^{{ }^{*}}$, Ana Odete Santos Vieira ${ }^{2, a}$ \& Lidyanne Yuriko Saleme Aona ${ }^{1, b}$}

${ }^{1}$ Programa de Pos-Graduação em Recursos Genéticos Vegetais, Universidade Federal do Recôncavo da Bahia, Centro de Ciências Agrárias, Ambientais e Biológicas, Cruz das Almas, Bahia, Brasil.

${ }^{2}$ Universidade Estadual de Londrina, Centro de Ciências Biológicas, Departamento de Biologia Animal e Vegetal, Londrina, Paraná, Brasil.

\begin{abstract}
Resumo - É apresentada a flora de Onagraceae para o estado da Bahia, Brasil. São reconhecidas 20 espécies, distribuidas em dois gêneros. Fuchsia, representado apenas por F. regia, é registrado pela primeira vez no estado. O gênero Ludwigia apresentou 19 espécies, sete delas são ocorrências novas para a Bahia: L. affinis, L. brachyphylla, L. elegans, L. decurrens, L. quadrangularis, L. sericea e L. torulosa. São apresentados chaves de identificação, descrições e comentários para os táxons, assim como fotos e mapas de distribuição para as espécies no estado.

Palavras-chave adicionais: florística, Fuchsia, Ludwigia, Nordeste do Brasil, novas ocorrências, taxonomia.
\end{abstract}

\begin{abstract}
Flora of Bahia: Onagraceae) - The flora of Onagraceae is presented for the Bahia State, Brazil. Twenty native species are recognized in two genera. Fuchsia, represented only by F. regia, is reported for the first time in the State. The genus Ludwigia presented 19 species, seven of which are new occurrences for Bahia: L. affinis, L. brachyphylla, L. elegans, L. decurrens, L. quadrangularis, L. sericea and L. torulosa. Identification keys, descriptions and comments for taxa as well as photos and distribution maps for species in the state are presented.

Additional keywords: floristics, Fuchsia, Ludwigia, Northeast Brazil, new occurrences, taxonomy.
\end{abstract}

Onagraceae é uma família monofilética, bem sustentada por estudos morfológicos, filogenéticos, bioquímicos e biogeográficos, e pertence à ordem Myrtales (Eyde 1981; Hoch et al. 1993; Conti et al. 1996, 1997; Levin et al. 2003, 2004; APG IV 2016). Possui 22 gêneros e 657 espécies (Zardini \& Raven 2003; Wagner et al. 2007), apresentando distribuição cosmopolita, ainda que a maioria das espécies esteja concentrada nas Américas, especialmente na América do Norte Ocidental (Zardini \& Raven 1992; Wagner et al. 2007).

No Brasil, Onagraceae apresenta aproximadamente 66 espécies e quatro subespécies, distribuídas em quatro gêneros. Três gêneros ocorrem principalmente nas Regiões Sudeste e Sul, Epilobium L. e Fuchsia L. em áreas de altitude, habitando florestas ombrófilas, e Oenothera L., associado à região litorânea; enquanto Ludwigia L. ocorre em todos os estados brasileiros, estando mais associado a regiões úmidas e alagadas (Munz 1947; Souza \& Lorenzi 2019; Zeferino et al. 2020). Na Bahia, Onagraceae estaria representada por 12 espécies de Ludwigia (Zeferino et al. 2020).

Durante expedições a campo entre 2013 e 2019, foram coletados 178 exemplares de Ludwigia em 73 municípios da Bahia; dentre entre, 24 ainda não contavam com registros do gênero. Juntamente com a visita aos herbários ALCB, BRBA, CEPEC, ESA, HRB, HUEFS, HUESB, HUNEB, HURB, HVASF, IAC, MAC, SP, SPF, UEC, UESC e PEUFR (Thiers 2020, continuamente atualizado) e imagens disponíveis nos

\footnotetext{
*Autora para correspondência: nelmamark@gmail.com;

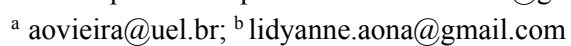

Editor responsável: Alessandro Rapini

Submetido: 14 set. 2020; aceito: 27 mar. 2021

Publicação eletrônica: 9 abr. 2021; versão final: 12 abr. 2021
}

sítios INCT-HerbárioVirtual da Flora e dos Fungos (2020) e Reflora-Herbário Virtual (2020) (indicadas com *), nossos estudos registraram espécimes de Onagraceae em 189 municípios baianos. Dentre as espécies que ocorrem na Bahia, apenas Fuchsia regia (Vand. ex Vell.) Munz, Ludwigia affinis (DC.) H.Hara, L. inclinata (L.f.) M.Gómez, L. quadrangularis (Micheli) H.Hara e L. sedoides (Bonpl.) H.Hara não foram encontradas em campo.

A observação de plantas em cultivo e no campo, associada à análise do material depositado nos herbários, permitiu reavaliar a circunscrição de espécies e identificar padrões relacionados à forma dos frutos e sementes (Figura 1). Por exemplo, frutos quadrangulares, subcilíndricos, obcônicos ou obpiramidais apresentam o nectário elevado, seguindo seu formato, mantendo-se plano apenas no ápice, onde se insere o estilete (Figuras 1V, W, FF, KK), enquanto o nectário permanece convexo com ápice plano em frutos cilíndricos. No geral, a descrição da morfologia das estruturas seguiu Radford et al. (1974) e Hickey \& King (2004).

Foram registrados dois gêneros, Fuchsia (F. regia) e Ludwigia (19 espécies; Figuras 2-4), totalizando 20 espécies de Onagraceae para a Bahia. Oito dessas espécies são novas ocorrências para o estado: F. regia, L. affinis, L. brachyphylla, L. decurrens, L. elegans, $L$. quadrangularis, L. sericea e L. torulosa.

\section{ONAGRACEAE}

Ervas, subarbustos, arbustos ou lianas, raramente árvores. Folhas alternas ou opostas, raramente verticiladas, simples, pecioladas ou sésseis, com ou sem estípula. Flores (2-)4- ou 5(-8)-mera, diclamídeas, 
bissexuadas ou raramente unissexuadas, actinomorfas ou raramente zigomorfas; hipanto prolongado sob o ovário, concrescido com o ovário em Ludwigia; sépalas livres, raramente conatas, decíduas após a antese (exceto em Ludwigia); pétalas livres, em número igual ao de sépalas; androceu diplostêmone ou raramente isostêmone em Ludwigia, geralmente 8-10 estames desiguais ou subiguais, anteras rimosas; nectário na base do hipanto, acima do ovário em Ludwigia; ovário ínfero, (2-)4- ou 5(-8)-carpelar, placentação axial, com 1 a numerosos óvulos anátropos por lóculo, 1 estilete com estigma variadamente capitado, claviforme, depressogloboso, globoso, subcapitado, subgloboso ou truncado. Frutos bagas ou cápsulas loculicidas, irregularmente deiscentes. Sementes 1 a numerosas por lóculo; endocarpo em volta da semente ou ausente, sem endosperma.

\section{Chave para os gêneros}

1. Folhas opostas ou verticiladas. Hipanto prolongado acima do ovário. Cálice decíduo. Corola púrpura. Fruto tipo baga 1. Fuchsia

1'. Folhas alternas ou verticiladas. Hipanto concrescido com o ovário. Cálice persistente. Corola amarela, amarelo-clara ou branca com mácula amarela. Fruto tipo cápsula 2. Ludwigia

\section{Fuchsia L.}

Arbustos a subarbustos, eretos a escandentes, ou lianas, raramente árvores até $12 \mathrm{~m}$ alt.. Folhas opostas ou verticiladas, elípticas, elíptico-ovadas a lanceoladoelípticas, subcoriáceas a coriáceas, margens inteiras a serrilhadas, pecioladas; estípulas pequenas, geralmente decíduas. Flores 4-meras, geralmente pêndulas, axilares, solitárias ou em inflorescências racemosas, ou paniculadas, bi ou unissexuadas, actinomorfas; hipanto prolongado acima do ovário, cilíndrico-fusiforme a obcônico; sépalas vermelhas, magentas, raramente verdes, decíduas, conatas na base, mais longas que o hipanto; pétalas púrpura, fortemente convolutas, às vezes diminutas, vários tons de roxo, vermelho ou laranja, raramente lavanda, rosa choque ou verde, mais curtas que as sépalas; androceu diplostêmone, estames desiguais, raramente em séries iguais, anteras extrorsas; nectário discoidal, adnato à base do hipanto ou quase totalmente livre dele, plano ou em cume; ovário 4-carpelar, 4-locular, estigma variadamente capitado, claviforme, globoso a subgloboso. Frutos bagas carnudas, verdes, arroxeadas ou pretas, oblongoides, oblongo-elipsoides ou subglobosas, pediceladas. Sementes poucas a ca. 500, acastanhadas, oblongas ou levemente achatado-piramidais, sem endocarpo.

Fuchsia possui morfologia singular, com frutos carnosos, flores pêndulas, geralmente polinizada por pássaros, e pólen biporado (Munz, 1947; Berry 1982; Berry et al. 2004). O gênero é monofilético (Sytsma et al. 1991; Sytsma \& Smith 1992; Berry et al. 2004) e compreende aproximadamente 110 espécies, classificadas em 11 seções (Berry et al. 2004). Está distribuído principalmente nos Andes tropicais, mas também ocorre no México, América Central, sudeste do Brasil, sul dos Andes, Nova Zelândia e Taiti, em ambientes frios e úmidos de regiões elevadas (Berry 1989).

As nove espécies de Fuchsia que ocorrem no Brasil pertencem a Fuchsia sect. Quelusia (Vand.) DC., nas Regiões Sul e Sudeste (Berry 1989; Berry et al. 2004; Zeferino et al. 2020). São utilizadas na ornamentação e o cultivo de mudas tem contribuído para a preservação das espécies nativas em seu hábitat natural (Barroso et al. 2007).

1.1. Fuchsia regia (Vand. ex Vell.) Munz, Proc. Calif. Acad. Sci., ser. 4, 25: 13. 1943.

Figura 5.

Nome popular: brinco-de-princesa.

Arbustos a subarbustos, levemente escandentes, ou lianas, 5-10 m alt.; caules acastanhados ou avermelhados, esparsamente pubescentes. Folhas com lâmina 2,2-9,2 × 1,1-3,3 cm, face adaxial verde-escura, brilhante, glabra, face abaxial verde-pálida, glabra, pubérula apenas na base da nervura central, elíptica, largo-elíptica a lanceolada, coriácea, ápice agudo a acuminado, base arredondada a levemente assimétrica, margens inteiras; pecíolo 3-13 mm compr.; estípula decídua. Flores solitárias ou em pares na axila das folhas das extremidades dos ramos; hipanto 6-9 $\mathrm{mm}$ compr., magenta; sépalas 3,2-4,8 cm × 2-4 mm, magentas, conatas na base, lanceoladas, ápice acuminado; pétalas 8-12 ×5-10 mm, púrpura, obovais, fortemente convolutas, ápice obtuso; estames desiguais, magentas, filetes epipétalos, 3,7-4,6 cm compr., epissépalos, 4,7-5,8 cm compr., anteras 2-3 $\mathrm{mm}$ compr.; nectário discoidal, adnato à base do hipanto, plano; estiletes 4,9-8,1 cm compr., magentas, estigma 3-4 mm compr., magenta, claviforme. Bagas 3-17 × 1$5 \mathrm{~mm}$, verdes, arroxeadas a pretas, oblongoides; pedicelo 2,6-8,8 cm compr., sem bractéolas. Sementes até ca. $1 \mathrm{~mm}$ compr., acastanhadas, levemente achatadopiramidais.

Ocorre nas Regiões Sul e Sudeste, nos domínios do Cerrado, Mata Atlântica e Pampa (Zeferino et al. 2020), sendo este o primeiro registro para a Bahia. G7, G8 e H8: sul e sudeste do estado, em regiões frias e úmidas, entre 650-1.000 m s.n.m., próximo a cursos d'água, no interior de mata, em florestas ombrófilas densas (Figura 5). Encontrada com flores e frutos de dezembro a janeiro e em abril.

Material selecionado - Almadina, Serra do Corcovado, 13,8 km a SW de Coaraci, na estrada para Almadina, fazenda São José, proprietário Senhor Francisco, 14²4'S, 39³6'W, 650-900 m s.n.m., 17 dez. 2006 (fl., fr.), R.A.X. Borges et al. 385 (CEPEC); Arataca, topo da Serra do Peito-de-Moça, ramal a ca. $22,4 \mathrm{~km}$ na estrada que liga Arataca à Una, com entrada no assentamento Santo Antônio, RPPN Caminho das Pedras, $15^{\circ} 10^{\prime}$ S, $39^{\circ} 20^{\prime} \mathrm{W}, 1.000$ m s.n.m., 15 abr. 2006 (fl., fr.), A.M. Amorim et al. 5806 (CEPEC, SPF); Boa 


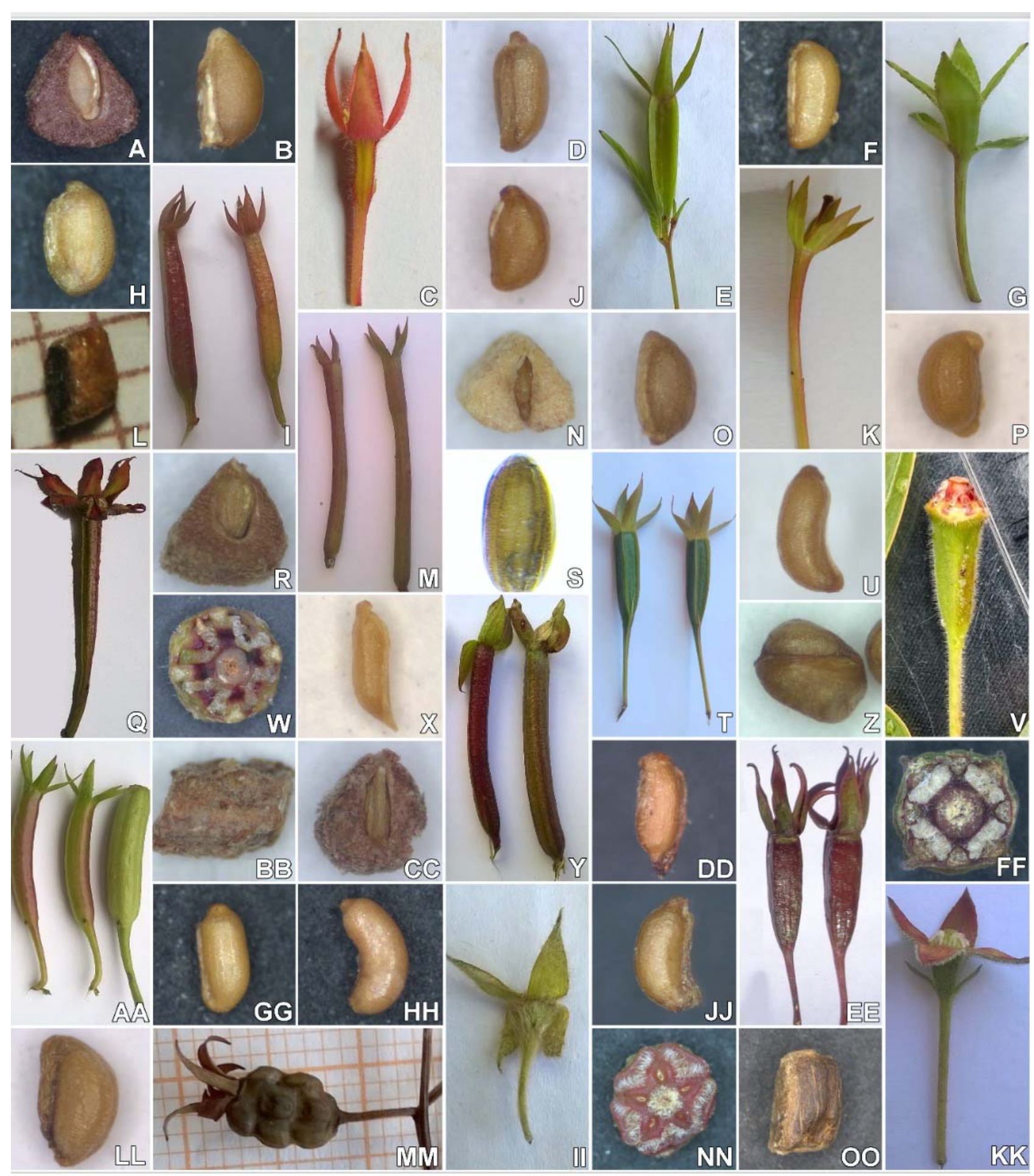

Figura 1. Frutos e sementes de Ludwigia. A, B. Ludwigia affinis: A- endocarpo corticoso em forma de ferradura envolvendo parcialmente a semente; B- semente oblongo-ovoide, rafe proeminente, com camada corticosa exposta. C, D. L. brachyphylla: C- cápsula levemente 4angular, hirsuta; D- semente oblongoide, rafe proeminente, com camada corticosa exposta. E, F. L. decurrens: E- cápsula 4-angular, 4-alada, glabra; F- semente oblongoide, rafe proeminente, com camada corticosa exposta. G, H. L. elegans: G- cápsula 4-angular, obcônica, glabra a pubescente, pincipalmente nos ângulos; H- semente oblongo-ovoide, rafe proeminente com camada corticosa exposta. I, J. L. erecta: I- cápsulas 4-angulares, oblongoides, alas ausentes, pubérulas a glabras; J- semente elipsoide, rafe proeminente, com camada corticosa exposta. K, L. L. helminthorrhiza: K- cápsula levemente 5-angular, subcilíndrica, glabrescente a glabra; L- endocarpo lenhoso truncado envolvendo totalmente a semente oblongo-ovoide. M-O. L. hyssopifolia: M- cápsulas com a região apical levemente 4-angular, pubérulas a glabras; N- endocarpo corticoso envolvendo parcialmente a semente da base do fruto, oblongo-ovoide; O- semente da parte apical do fruto, oblongo-ovoide, não envolvida pelo endocarpo, com rafe proeminente. P. L. inclinata: semente elipsoide, rafe proeminente, com camada corticosa exposta. Q-S. L. leptocarpa: Q- cápsula subcilíndrica, pilosa a glabra; R- endocarpo corticoso em forma de ferradura envolvendo parcialmente a semente; S- semente oblonga-achatada, rafe proeminente com camada corticosa exposta. T, U. L. longifolia: T- cápsulas 4angulares, oblongoides, estreitamente 4-aladas, glabras; $\mathbf{U}$ - semente oblongoide, extremidade basal curvada, rafe proeminente com camada 
Figura 1 (cont.). corticosa exposta sobre a extremidade basal curvada. V-X. L. nervosa: V-cápsula cilíndrica-obcônica, pubescente a glabra; W- nectário convexo, ápice plano; $\mathbf{X}$ - semente oblongoide, rafe proeminente, com camada corticosa exposta e extremidade basal pontiaguda, em forma de cone. Y, Z. L. octovalvis: Y-cápsulas cilíndricas, pubérulas a glabrescentes; Z- semente globosa, com rafe expandida, sem camada corticosa exposta. AA, BB. L. peploides: AA- cápsulas levementes 5-angulares, subcilíndricas, glabras; BB- endocarpo lenhoso, obliquotruncado em suas extremidades, envolvendo totalmente a semente depresso-ovalada. CC, DD. L. quadrangularis: CC- endocarpo corticoso em forma de ferradura envolvendo parcialmente a semente; DD - semente oblongo-ovoide, rafe proeminente com camada corticosa exposta. EEGG. L. rigida: EE- cápsulas 4(5)-angulares, obcônicas, pubérulas a glabras; FF- nectário piramidal, 4(5)-angular, ápice plano; GG- semente oblongoide, rafe proeminente, com camada corticosa exposta e extremidade basal curvada sobre o tegumento. HH. L. sedoides: semente oblongoide, levemente falciforme, rafe inconspícua. II, JJ. L. sericea: cápsula 4-angular, obcônica e obpiramidal, pilosa; JJ- semente elipsoide, rafe proeminente com camada corticosa exposta. KK, LL. L. tomentosa: KK- cápsula 4-angular, obpiramidal, pubescente; LL- semente largoelipsoide, rafe bem proeminente com camada corticosa exposta. MM-OO. L. torulosa: MM- cápsula oblongoide, torulosa, protuberâncias laterais presentes, glabra; NN- nectário subcircular, plano; OO- endocarpo lenhoso truncado envolvendo totalmente a semente elíptico-globosa (A, B- Árbocz 4277; P- Jardim 3384; CC, DD- Alves 419; HH- Oliveira 498; MM- Pivari 74;OO- Santos 2987; NN- Fonseca 398).

Nova, fazenda São José, $88 \mathrm{~km}$ de Boa Nova, na estrada para Dário Meira, a $14 \mathrm{~km}$ do ramal à esquerda, $14^{\circ} 23^{\prime} \mathrm{S}, 40^{\circ} 08^{\prime} \mathrm{W}, 850 \mathrm{~m}$ s.n.m., 7 jan. 2001 (fl., fr.), A.M. Amorim et al. 3596 (CEPEC, SPF).

Fuchsia regia pode ser reconhecida pelas flores pêndulas, com hipanto de 6-9 mm compr., magenta; sépalas 3,2-4,8 cm $\times 2-4 \mathrm{~mm}$, magenta, fusionadas na base, mais longas que o hipanto; corola púrpura, formando um cone ao redor dos estames e estilete. Apresenta estames desiguais, de coloração magenta, exsertos, características da seção Quelusia (sensu Berry 1989), estilete e estigma de coloração magenta, exsertos, e frutos oblongoides, verdes, tornando-se de arroxeados a pretos quando maduro.

\section{Ludwigia L.}

Ervas, subarbustos e arbustos, eretos, levemente escandentes, prostrados, flutuantes fixos ou livres, ou submersos; caules cilíndricos a subcilíndricos, ramificados a muito ramificados, hirsutos, pilosos, pubescentes, pubérulos, glabrescentes a glabros; raízes laterais ou nodais fibrosas, pneumatóforos brancos, raros a abundantes. Folhas alternas, raro verticiladas, simples, cartáceas, coriáceas ou membranáceas, margens inteiras, ou levemente serrilhadas pelos hidatódios epitemais ou irregularmente serrilhadas pelos hidatódios glandulares disformes e avermelhados, sésseis ou pecioladas, com estípula. Flores 4- ou 5(-8)meras, solitárias, axilares, bissexuadas, actinomorfas; hipanto concrescido com o ovário; sépalas verdes, verde-avermelhadas a verde-vináceas, persistentes; pétalas amarelas, amarelo-claras ou brancas com máculas amarelas, decíduas; androceu iso ou diplostêmone, estames desiguais ou subiguais, amarelos, anteras extrorsas; nectário subcircular ou 4angular, plano, convexo a levemente convexo, piramidal, 4- ou 5-angular, ápice plano; ovário 4- ou 5(8)-carpelar e 4- ou 5(-8)-locular, óvulos uni e plurisseriados em cada lóculo, estilete amarelo, estigma amarelo, variadamente capitado, depresso-globoso, globoso, subcapitado ou truncado. Cápsulas verdes, verde-avermelhadas a verde-vináceas, loculicidas, irregularmente deiscentes, 4- ou 5(-8)-angulares ou sem ângulos, cilíndricas, subcilíndricas, oblongoides, obcônicas a obpiramidais, bractéolas conspícuas ou não, 2 na base do fruto e raramente no pedicelo. Sementes plurisseriadas, não envolvidas pelo endocarpo e/ou unisseriadas e parcial ou totalmente envolvidas pelo endocarpo corticoso ou lenhoso, liberadas durante a desintegração das paredes do fruto; rafe expandida, sem camada corticosa exposta, inconspícua, proeminente ou bem proeminente, com camada corticosa exposta.

Ludwigia é composto por cerca de 82 espécies e apresenta distribuição pantropical, sendo predominantemente sul-americano (Raven 1988; Zardini \& Raven 1992; Wagner et al. 2007). Grande parte de sua diversidade, cerca 50 espécies, ocorre na América do Sul (Ramamoorthy \& Zardini 1987; Raven 1988; Wagner et al. 2007). Estudos filogenéticos sustentam o monofiletismo de Ludwigia e sua posição como grupo irmão das demais Onagraceae (Levin et al. 2003, 2004; Wagner et al. 2007; Liu et al. 2017).

Suas espécies estão organizadas em 23 seções com base na placentação do ovário (Wagner et al. 2007). Os arranjos unisseriados ou plurisseriados dos óvulos e a presença ou não de tecido endocárpico persistente em torno das sementes são características evolutivamente importantes (Skvarla et al. 1975; Eyde 1977, 1978, 1981; Hoch et al. 1993), utilizadas na classificação infragenérica (Raven 1963; Wagner et al. 2007; Hoch et al. 2015). Assim, organizamos este tratamento a partir das seções de Wagner et al. (2007) e Hoch et al. (2015).

\section{Chave para as espécies}

1. Corola amarela, amarelo-clara ou branca com mácula amarela, 4- ou 5(-8)-mera. Sementes unisseriadas em cada lóculo, envolvidas pelo endocarpo lenhoso truncado e corticoso em forma de ferradura, pelo menos na base da cápsula.

2. Corola amarela, 4-mera. Sementes unisseriadas parcialmente envolvidas pelo endocarpo corticoso na base da cápsula e plurisseriadas não envolvidas pelo endocarpo no ápice da cápsula 
2'. Corola amarela, amarelo-clara ou branca com mácula amarela, 4- ou 5(-8)-mera. Sementes unisseriadas em cada lóculo, parcial ou totalmente envolvidas pelo endocarpo lenhoso ou corticoso.

3. Ervas a subarbustos eretos ou subarbustos levemente escandentes. Corola amarela, 4- ou 5(-8)-mera; androceu diplostêmone. Sementes parcialmente envolvidas pelo endocarpo corticoso em forma de ferradura Sect. Seminuda

4. Subarbustos levemente escandentes; ramos densamente pubérulos a glabros, esbranquiçados nas extremidades. Folhas ovais, com extremidades assimétricas, ou orbiculares, base arredondada, coriáceas. Flores 4-meras 2.19. L. quadrangularis

4'. Ervas a subarbustos eretos ou subarbustos levemente escandentes; ramos densamente hirsutos a pilosos, acastanhados a esbranquiçados nas extremidades. Folhas elípticas, largo-elípticas, lanceoladas, oblanceoladas, ovais, base aguda, arredondada ou atenuada, membranáceas. Flores 5(8)-meras.

5. Plantas levemente escandentes; ramos densamente hirsutos, anguloso-curvados, acastanhados nas extremidades. Folhas elípticas, largo-elípticas, ovais, base aguda a arredondada. Flores 5(6)-meras. Sementes oblongo-ovoides 2.17. L. affinis

5'. Plantas eretas; ramos densamente pilosos, eretos, esbranquiçados nas extremidades. Folhas elípticas, lanceoladas, oblanceoladas, base atenuada. Flores 5(-8)-meras. Sementes oblongoachatadas

2.18. L. leptocarpa

3'. Ervas a subarbustos eretos ou ervas prostradas, flutuantes fixas ou livres. Corola amarela, amarelo-clara ou branca com mácula amarela, 5(6)-mera; androceu isostêmone ou diplostêmone. Sementes envolvidas totalmente pelo endocarpo truncado, lenhoso sect. Jussiaea

6. Androceu isostêmone. Corola amarelo-clara, 5(6)-mera. Cápsulas oblongoides, torulosas, com protuberâncias nas regiões das sementes ................................................................... 2.6. L. torulosa

6'. Androceu diplostêmone. Corola inteiramente amarela ou branca com mácula amarela, 5-mera. Cápsulas levemente 5-angulares, subcilíndricas.

7. Plantas flutuantes fixas, com raízes nodais fibrosas e raros pneumatóforos esponjosos nos ramos. Corola inteiramente amarela 2.5. L. peploides

7'. Plantas flutuantes fixas ou livres, com raízes nodais fibrosas e abundantes pneumatóforos brancos nos ramos. Corola branca com mácula amarela .

2.4. L. helminthorrhiza

1'. Corola amarela, 4(5)-mera. Sementes plurisseriadas em cada lóculo, não envolvidas pelo endocarpo.

8. Ervas prostradas a flutuantes fixas ou submersas.

9. Plantas flutuantes fixas ou submersas. Folhas dimórficas, as distais alternas ou dispostas em espiral, oblanceoladas a obovais, as basais submersas verticiladas, oblanceoladas a estreitamente oblanceoladas, margens inteiras. Sementes elipsoides ............................................ sect. Heterophylla. 2.2. L. inclinata

9'. Plantas flutuantes fixas. Folhas monomórficas, dispostas em rosetas, rômbicas-ovaladas, margens crenado-serrilhadas distalmente, inteiras na metade inferior. Sementes oblongoides, levemente falciformes sect. Humboldtia. 2.3. L. sedoides

$8^{\prime}$. Ervas a arbustos eretos, terrestres.

10. Sementes globosas; rafe sem camada corticosa exposta sect. Macrocarpon. 2.7. L. octovalvis

10'. Sementes elipsoides, largo-elipsoides, oblongoides, oblongo-ovoides; rafe com camada corticosa exposta.

11. Plantas anuais. Caule 4-angular ou levemente 4-angular, ou subcilíndrico, 4-alado ou estreitamente 4-alado. Folhas com base decorrente ou levemente decorrente apenas nas extremidades dos ramos. Cápsulas 4-angulares, aladas ou não, oblongoides sect. Pterocaulon

12. Caule 4-angular, 4-alado, em decorrência da base das folhas. Folhas com base arredondada, decorrente. Cápsulas 4-aladas

2.14. L. decurrens

12'. Caule subcilíndrico a levemente 4-angular, estreitamente 4-alado, apenas nas extremidades dos ramos, em decorrência da base das folhas. Folhas com base aguda, levemente decorrente apenas nas extremidades dos ramos. Cápsulas estreitamente 4-aladas ou sem alas.

13. Caule subcilíndrico a levemente 4 -angular. Cápsulas sem alas. Sementes elipsoides, sem extremidade basal curvada 2.15. L. erecta

13'. Caule levemente 4-angular. Cápsulas estreitamente 4-aladas. Sementes oblongoides, com extremidade basal curvada 2.16. L. longifolia

11'. Plantas anuais a perenes. Caule cilíndrico ou subcilíndrico, sem alas. Folhas com base não decorrente. Cápsulas 4(5)-angulares a levemente 4(5)-angulares, sem alas, cilíndrico-obcônicas, obcônicas, obpiramidais

14. Caule subcilíndrico. Sementes largo-elipsoides ou oblongo-ovoides. sect. Myrtocarpus

15. Ramos densamente pubescentes e com tricomas esbranquiçados nas extremidade. Folhas com margens levemente serrilhadas pelos hidatódios epitemais. Estames com filetes e 
anteras curvados, próximos às pétalas. Cápsulas 4-angulares, obcônicas. Sementes oblongo-ovoides ........................................................................ 2.9. L. elegans

15'. Ramos densamente tomentosos e com tricomas acastanhados a alvo-acinzentados nas extremidades. Folhas com margens irregularmente serrilhadas pelos hidatódios glandulares disformes e avermelhados. Estames com filetes e anteras eretos a levemente curvados, quase aproximando-se das pétalas. Cápsulas 4(5)-angulares, obpiramidais. Sementes largo-elipsoides 2.13. L. tomentosa

14'. Caule cilíndrico ou subcilíndrico. Sementes elipsoides ou oblongoides.

16. Caule subcilíndrico; ramos densamente seríceos a seríceo-tomentosos e com tricomas alvo-acinzentados nas extremidades. Cápsulas 4-angulares, obpiramidais e obcônicas. Sementes elipsoides 2.12. L. sericea

16'. Caule cilíndrico ou subcilíndrico; ramos densamente hirsutos ou densa a esparsamente pubescentes a pubérulos e com tricomas esbranquiçados nas extremidades. Cápsulas 4(5)-angulares ou levemente 4-angulares, obcônicas, cilíndrico-obcônicas. Sementes oblongoides.

17. Ramos densamente hirsutos nas extremidades. Folhas com ápice acuminado e mucronado, margens inteiras. Cápsulas levemente 4-angulares, obcônicas

2.8. L. brachyphylla

17'. Ramos densa ou esparsamente pubescentes a pubérulos nas extremidades. Folhas com ápice acuminado ou agudo, raro obtuso, margens inteiras ou levemente serrilhadas pelos hidatódios epitemais. Cápsulas cilíndrico-obcônicas, 4(5)angulares, obcônicas.

18. Ramos densamente pubescentes a pubérulos nas extremidades. Folhas com ápice agudo, raro obtuso. Estames desiguais, filetes e anteras eretos; estilete 1-1,2 mm compr. Cápsulas cilíndrico-obcônicas; rafe com extremidade basal pontiaguda, cônica 2.10. L. nervosa

18'. Ramos esparsamente pubescentes a pubérulos nas extremidades. Folhas com ápice acuminado ou agudo. Estames subiguais, filetes curvados e anteras levemente curvadas, quase aproximando-se das pétalas; estilete $2-3,6 \mathrm{~mm}$ compr. Cápsulas 4(5)-angulares, obcônicas; rafe com extremidade basal curvada sobre o tegumento

2.11. L. rigida

Ludwigia sect. Fissendocarpa (Haines) P.H.Raven, Reinwardtia 6: 335. 1964.

Caules subcilíndricos, eretos, com raízes laterais fibrosas e raros pneumatóforos brancos. Folhas alternas com margens inteiras. Corola amarela; androceu diplostêmone. Cápsulas com a região apical levemente 4-angular e a basal subcilíndrica, com paredes finas, irregularmente deiscentes. Sementes plurisseriadas no ápice do fruto não envolvidas pelo endocarpo e unisseriadas na base do fruto envolvidas quase totalmente pelo endocarpo corticoso; rafe com camada corticosa exposta. Número cromossômico: $\mathrm{n}=8$.

Esta seção é representada somente por L. hyssopifolia.

\subsection{Ludwigia hyssopifolia (G.Don) Exell, Garcia de} Orta 5: 471. 1957.

Figuras 1M-O, 2C, D e 9; Munz (1947: fig. 29), Wagner

(2007: fig. 7) e Lovo \& Zappi (2018: fig. 2D-G).

Nome popular: pimenta-d'água-da-miúda.

Ervas a subarbustos, anuais, eretos, $0,2-2 \mathrm{~m}$ alt.; caules muito ramificados, glabrescentes a glabros, com ramos esparsamente pubérulos e esbranquiçados nas extremidades. Folhas com lâmina 3-9 × 1-3 cm, face adaxial verde a verde-avermelhada, face abaxial verde, glabra, lanceolada, membranácea, ápice acuminado a agudo, base acuminada; pecíolo 2-15 $\mathrm{mm}$ compr.; estípula $0,7-1 \mathrm{~mm}$ compr. Flores $4-m e r a s, 0,8-1 \mathrm{~cm}$ compr.; sépalas $2-4,4 \times$ ca. $1 \mathrm{~mm}$, face adaxial verde, a abaxial verde a verde-avermelhada, glabras, lanceoladas, ápice agudo; pétalas 3-5 × 1-2 mm, elípticas, ápice agudo; estames desiguais, filetes $\mathrm{e}$ anteras eretos; nectário convexo, ápice plano; estigma subcapitado. Cápsulas 1,8-2,9 cm × 1,5-2 mm, verdes, verde-avermelhadas a verde-vináceas, pubérulas a glabras, sésseis; bractéola $0,5-1 \mathrm{~mm}$ compr., na base dos frutos. Sementes ca. $5 \times 2 \mathrm{~mm}$, no ápice do fruto, amarelo-acastanhadas, oblongo-ovoides; rafe proeminente, de comprimento igual ao das sementes; sementes ca. $7 \times 3 \mathrm{~mm}$, na base do fruto, amareloacastanhadas, oblongo-ovoides; rafe bem proeminente, de comprimento igual ao das sementes.

Amplamente distribuída no Brasil, ocorre na Amazônia, Mata Atlântica e Pantanal, no Acre, Alagoas, Amapá, Amazonas, Bahia, Ceará, Goiás, Maranhão, Mato Grosso, Minas Gerais, Pará, Paraíba, Pernambuco, Piauí, Rio de Janeiro, Rondônia e Roraima (Zeferino et al. 2020). A5, A6, D2, D5, D9/10, E6, E7, E8/9, G5, G6 e G8/9: Caatinga, Cerrado e Mata Atlântica (Figura 9), associada a matas ciliares, nas margens e leito dos ambientes aquáticos permanentes ou temporários, limpos ou antropizados, como brejos, lagos, rios, riachos e cachoeiras, em solos arenosos, siltosos e argilosos. Coletada com flores e frutos em todos os meses do ano. 

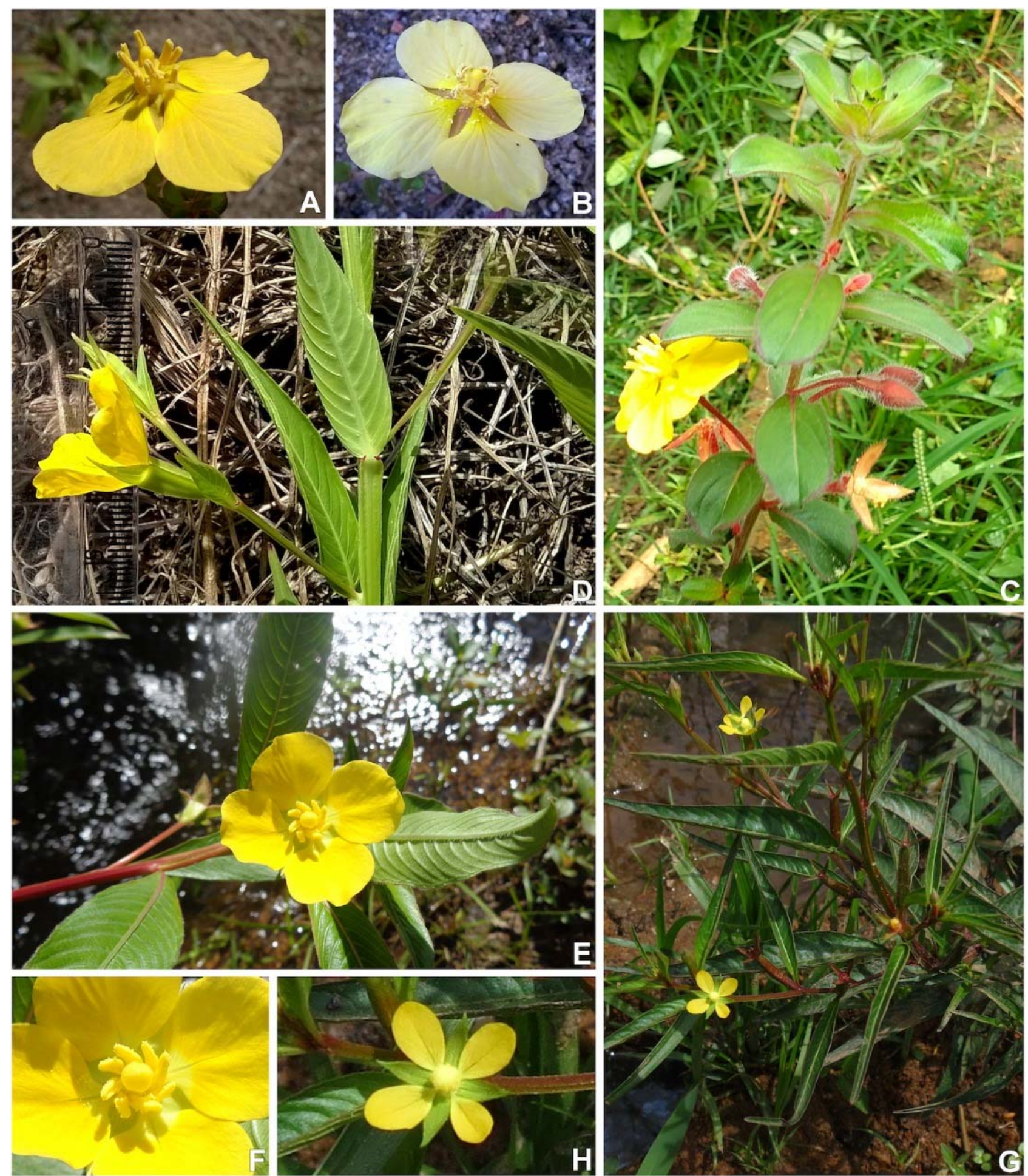

Figura 2. A-C. Ludwigia brachyphylla: A- flor amarela em antese, apresentando estames eretos; B- flor amarelo-clara na senescência; C- hábito desmontrando o indumento hirsuto esbranquiçado. D. L. decurrens: ramo angulado e alado. E, F. L. elegans: E- ramo com flor; F- flor em detalhe, com anteras curvadas e estigma capitado. G, H. L. erecta: G- hábito com flores; H- flor com pétalas amarelas.

Material selecionado - Andaraí, estrada BA-142, margens do rio Paraguaçu, $12^{\circ} 82^{\prime}$ 'S, $41^{\circ} 32^{\prime} \mathrm{W}, 327,5$ m s.n.m., 13 ago. 2016 (fl., fr.), N.X.M. Sousa 155 (HURB); Anguera, Lagoa 6, Km 23,1, lado SW, $12^{\circ} 10^{\prime}$ 'S; 39¹2’W, 3 nov. 1996 (fl., fr.), E. Melo et al. 1808 (MBM*); Barra do Mendes, povoado São Bento, $11^{\circ} 48^{\prime} \mathrm{S}, 42^{\circ} 5^{\prime} \mathrm{W}$, 720 m s.n.m., 25 out. 2009 (fl., fr.), E. Melo et al. 6825 (ALCB, HUEFS); Barreiras, Área do CEFET, perto da margem esquerda do Rio Grande, sentido Salvador/Brasília, $12^{\circ} 3^{\prime} \mathrm{S}, 45^{\circ} 00^{\prime} \mathrm{W}, 483 \mathrm{~m}$ s.n.m., 30 maio 2007 (fl., fr.), M.M.M. Chaves 11 (HUEFS); Boninal, margens do rio Cochó, próximo à ponte da estrada Boninal/povoado Caititu, 25 abr. 2014 (fl., fr.), N.X.M. Sousa 15 (ALCB, HURB, SPF); Brumado, estrada Itaquaraí-Iguatemi, às margens do rio São João,

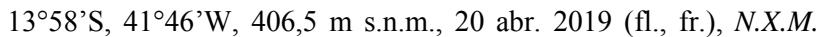
Sousa et al. 635 (HURB); Cachoeira, vila São Francisco do Iguape, Baia do Iguape, comunidade Kalumba, Apiário II, entrada à direita, $12^{\circ} 38^{\prime}$ S, $38^{\circ} 51^{\prime} \mathrm{W}, 117$ m s.n.m., 7 jun. 2013 (fl., fr.), J.A. Reis 37 

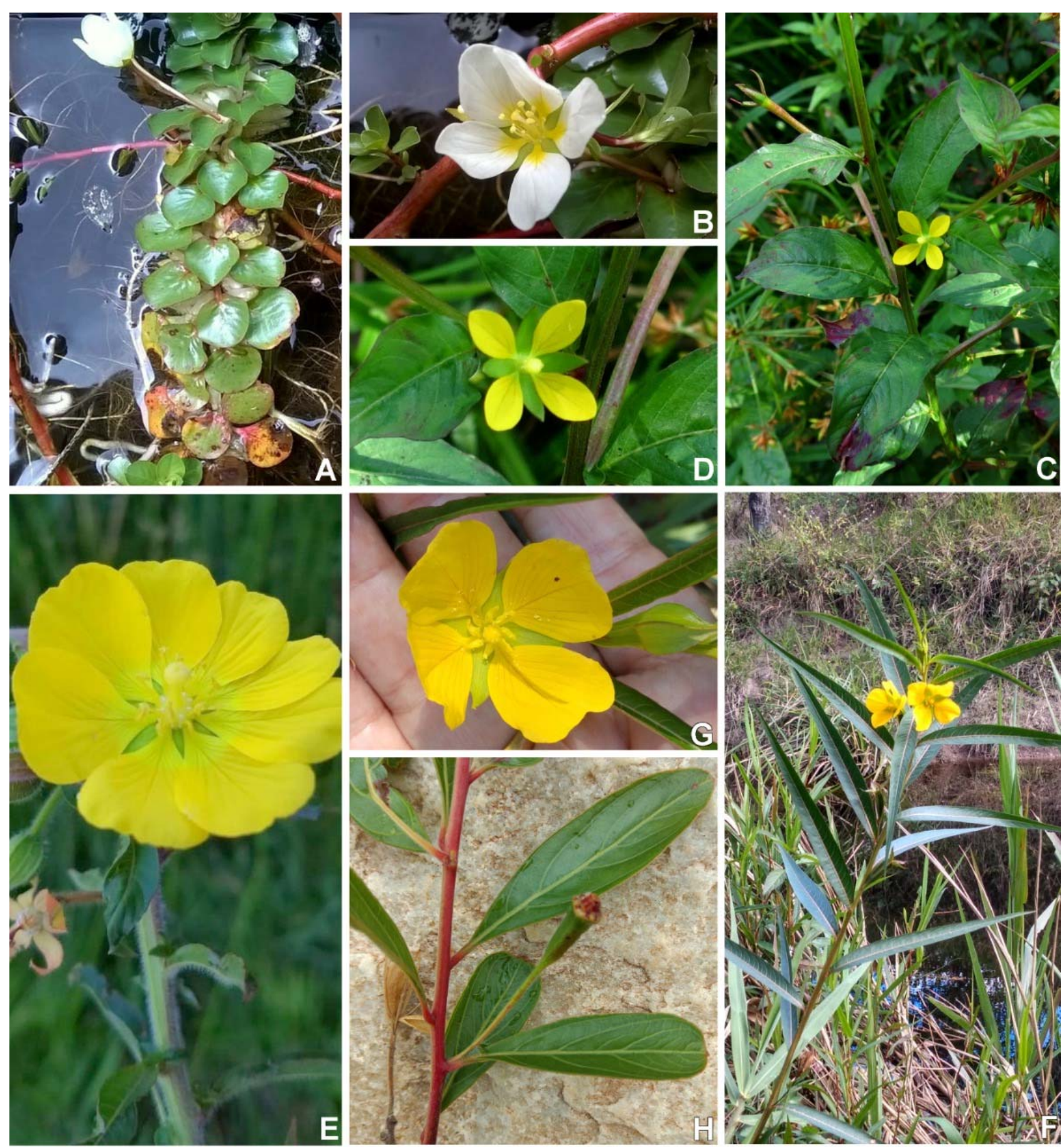

Figura 3. A, B. Ludwigia helminthorrhiza: A- hábito aquático; B- flor de pétalas brancas com mácula amarela na base. C, D. L. hyssopifolia: C- hábito; D- flor com pétalas amarelas. E. L. leptocarpa: flor com pétalas de ápice arredondado, emarginado. F, G. L. longifolia: F- hábito; G- flor com anteras levemente curvadas. H. L. nervosa: ramo apresentando folhas e fruto.

(HURB); Caitité, Brejinho das Ametistas, área da Bahia Mineração, $14^{\circ} 15^{\prime}$ 'S, $42^{\circ} 31^{\prime} \mathrm{W}, 845$ m s.n.m., abr. 2008, M.S. Mendes et al. 546 (HUEFS); Camaçari, Aldeia de Arembepe, 20 set. 2017 (fl., fr.), G. Costa et al. 2760 (HURB); Casa Nova, arredores da represa de Sobradinho, $09^{\circ} 21^{\prime}$ 'S, $40^{\circ} 47^{\prime}$ W, 392 m s.n.m., 5 jul. 2009 (fl., fr.), J. Paula-Souza et al. 9819 (SPF); Castro Alves, próximo ao loteamento Edson C. Leão, $12^{\circ} 45^{\prime}$ S, 39²6'W, 257 m s.n.m., 22 jul. 2015 (fl., fr.), N.X.M. Sousa 126 (HURB); Coaraci, BA-262, sentido Almadina, fazenda do lado esquerdo, após $5 \mathrm{~km}$ de Coaraci, 14³9' $\mathrm{S}$, 39³3'W, 188 m s.n.m., 13 nov. 2019, N.X.M. Sousa et al. 745 (HURB); Contendas do Sincorá, Floresta Nacional, 5 ago. 2016 (fl., fr.), G. Costa et al. 1944 (HURB); Cruz das Almas, área da UFRB, Fonte das Nações, 11 abr. 2008 (fl., fr.), L.Y.S. Aona et al.1109 (HURB); Dom Macedo Costa, primeira entrada à esquerda, antes da cidade, lagoa, 10 fev. 2015 (fl., fr.), G. Costa et al. 1232 (HURB); Esplanada, Vale do Itapicuru, 15 dez. 1950 (fr.), G.P. Pinto s.n. (ALCB 9248, IAC 15455); Feira de Santana, Represa de Bananeira, 12³2'S, 3903'W, 31 jul. 1980 (fl., fr.), L.R. Noblick 1968 (CEPEC, HUEFS); Formosa do Rio Preto, arredores da cidade, $11^{\circ} 03^{\prime} \mathrm{S}$, $45^{\circ} 11^{\prime}$ W, 480 m s.n.m., 29 abr. 2000 (fl., fr.), F. França et al. 3257 (ALCB, CEPEC, HUEFS, HUNEB, HRB); Governador Mangabeira, lagoa próxima à Barragem Pedra do Cavalo, $12^{\circ} 33^{\prime} \mathrm{S}$, 

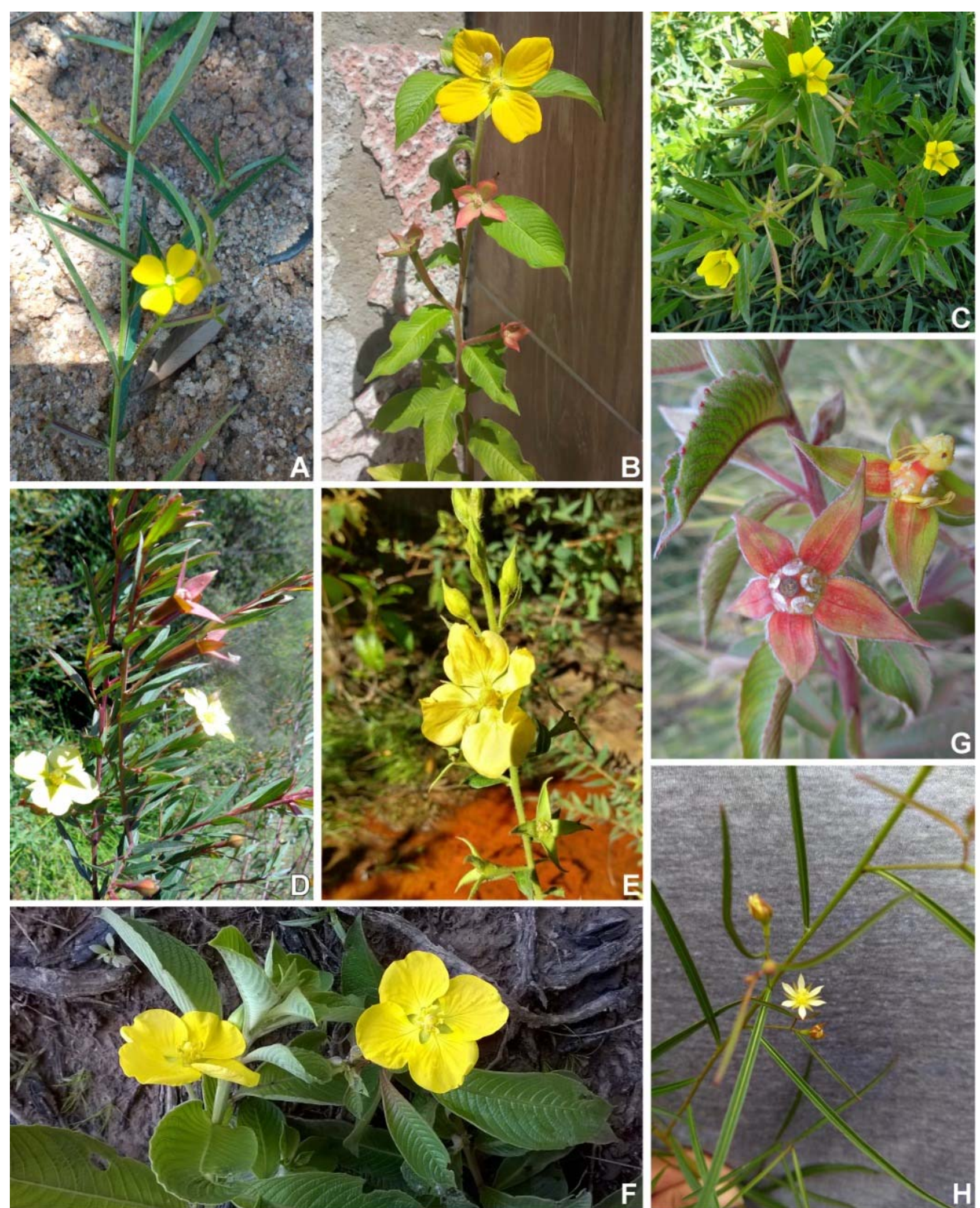

Figura 4. A, B. Ludwigia octovalvis: A- ramo com flor; B- hábito e flor com ápice arredondado, emarginado (foto: B- Lucas Cardoso Marinho). C. L. peploides: hábito, com flores. D. L. rigida: hábito com flores. E. L. sericea: ramo, com flor amarela e botões florais. F, G. L. tomentosa: F- ramo com flores; G- ramo com flores após a queda da corola, note as margens foliares irregularmente serrilhadas pelos hidatódios glandulares disformes e avermelhados, e o disco nectarífero piramidal de ápice plano. H. L. torulosa: ramo com flor (foto: Fonseca 398).

$39^{\circ} 02^{\prime} \mathrm{W}, 149$ m s.n.m., 18 set. 2016 (fl., fr.), N.X.M. Sousa et al. 204 (HURB); Igrapiúna, Pedra Branca, Litoral Sul, 1354'S, 39¹9’W, 21 jul. 2010 (fl., fr.), M.L. Guedes et al. 17513 (ALCB); Ilhéus, Km 1 Ilhéus-Olivença, próximo ao hotel Praia do Sol, 21 nov. 2014 (fl., fr.), N.X.M. Sousa 42 (HURB); Itaberaba, BR-242, aproximadamente $15 \mathrm{~km}$ depois da sede, sentido Seabra, $12^{\circ} 30^{\prime} \mathrm{S}$, $40^{\circ} 26^{\prime}$ W, 332,5 m s.n.m., 16 jun. 1918 (fl., fr.), N.X.M. Sousa et al. 328 (ALCB, HURB); Ituberá, sentido Pratigi, $13^{\circ} 75^{\prime} \mathrm{S}, 39^{\circ} 25^{\prime} \mathrm{W}$, 
20 maio 2016 (fl., fr.) M.L. Guedes et al. 24799 (ALCB, HURB); Jacaraci, rodovia Jacaraci-Condeúba, nas margens ao lado da ponte do rio Gavião, $14^{\circ} 52^{\prime}$ 'S, $42^{\circ} 00^{\prime} \mathrm{W}, 631$ ms.n.m., 12 nov. 2019 (fl., fr.), N.X.M. Sousa et al. 738 (HURB); Jaguaripe, depois da área da Petrobrás, 27 set. 2014 (fl., fr.), N.X.M. Sousa et al. 41 (HURB); Jequié, bairro Mandacaru, ao lado da estrada de ferro,

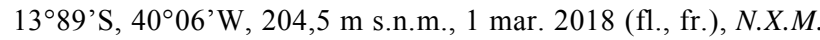
Sousa et al. 273 (HURB); Lagoa Real, povoado Tapera, na margem do rio São João, $14^{\circ} 14^{\prime}$ 'S, $42^{\circ} 15^{\prime} \mathrm{W}, 545,5$ m s.n.m., 4 mar. 2019 (fl., fr.), N.X.M. Sousa et al. 584 (HURB); Muniz Ferreira, fazenda Sete Brejos, córrego sob a ponte, $13^{\circ} 01^{\prime} \mathrm{S}$, $39^{\circ} 07^{\prime} \mathrm{W}, 5$ maio 2015 (fr.), W.O. Fonseca 144 (HURB); Muritiba, borda da lagoa, $1 \mathrm{~km}$ depois do portal da entrada, 182 m s.n.m., 12 nov. 2014 (fl., fr.), L.Y.S. Aona 3596 (HURB); Nazaré das Farinhas, 27 ago. 2015 (fl., fr.), N.X.M. Sousa et al. 144 (HURB, MAC); Rafael Jambeiro, BR-242, Km 125, à direita, $3 \mathrm{~km}$ após a entrada de Rafael Jambeiro, $12^{\circ} 32^{\prime} \mathrm{S}$, 39³4'W, 176 m s.n.m., 16 jul. 2018 (fl., fr.), N.X.M. Sousa et al. 323 (HURB); Remanso, estrada Remanso-Pilão Arcado, $30 \mathrm{~km}$ depois de Remanso, ao lado da ponte, $09^{\circ} 45^{\prime} \mathrm{S}, 42^{\circ} 17^{\prime} \mathrm{W}, 411 \mathrm{~m}$ s.n.m., 11 out. 2004 (fl., fr.), L.P. Queiroz et al. 9673 (HUEFS); Santo Amaro, 12 ${ }^{\circ} 33^{\prime}$ S, $38^{\circ} 40^{\prime} \mathrm{W}, 22$ set. 2014 (fl., fr.), N.X.M. Sousa et al. 37 (HURB); Santo Antônio de Jesus, estrada vicinal da BR-101, lado esquerdo, sentido Teolândia, $13^{\circ} 00^{\prime} \mathrm{S}, 39^{\circ} 15^{\prime} \mathrm{W}$, 29 jan. 2015 (fl., fr.), N.X.M. Sousa et al. 109 (HURB); Sento Sé, área proposta do Parque Nacional Boqueirão da Onça, fazenda Brejinho, no rio Bazuá, $09^{\circ} 56^{\prime} \mathrm{S}, 41^{\circ} 30^{\prime} \mathrm{W}, 460 \mathrm{~m}$ s.n.m., 11 jul. 2014 (fl., fr.), J.A. Siqueira Filho et al. 3176 (HURB, HVASF); São Felipe, Umbuzeiro, 12 dez. 2013 (fl., fr.), G. Costa et al. 831 (HURB); São Félix, margem do rio Paraguaçu, 3 jul. 2011 (fl., fr.), F. Esteves (HUEFS 179026); São Francisco do Conde, São Bento, rua do cais, próximo ao lago, $12^{\circ} 36^{\prime} \mathrm{S}, 38^{\circ} 41^{\prime} \mathrm{W}, 22$ set. 2014 (fl., fr.), N.X.M. Sousa et al. 33 (HURB); São Gonçalo dos Campos, chácara Sinhá, $2 \mathrm{~km}$ da entrada para S. Gonçalo a partir da BR-101, $12^{\circ} 25^{\prime}$ 'S, $38^{\circ} 55^{\prime} \mathrm{W}, 219$ m s.n.m., 12 nov. 2014 (fl., fr.), L.Y.S. Aona 3625 (HURB); Sapeaçu, rua Hipólito Fonseca, baixa da Palmeira, lagoa, $12^{\circ} 44^{\prime} \mathrm{S}, 39^{\circ} 13^{\prime} \mathrm{W}, 221 \mathrm{~m}$ s.n.m., 17 ago. 2015 (fl., fr.), L.Y.S. Aona et al. 4120 (HURB); Serra Preta, Distrito de Bravo, lagoa, $12^{\circ} 10^{\prime}$ S, $39^{\circ} 27^{\prime} \mathrm{W}, 247$ m s.n.m., 15 jul. 2018 (fl., fr.), N.X.M. Sousa et al. 508 (HURB); Urandi, BA-263, sentido Licínio de Almeida-Urandi, lado esquerdo, a $9 \mathrm{~km}$ da cidade, solo arenoso, cachoeira, $14^{\circ} 44^{\prime} \mathrm{S}, 42^{\circ} 35^{\prime}$ 'W, 846 m s.n.m., 11 nov. 2019 (fl., fr.), N.X.M. Sousa et al. 735 (HURB); Wenceslau Guimarães, rodovia BA-120, povoado Indaiá, ao lado da Unidade de Saúde da Família, 134ㄷ' 'S, 39³1'W, 109 m s.n.m., 8 jul. 2018 (fl., fr.), N.X.M. Sousa et al. 297 (HURB).

Ludwigia hyssopifolia apresenta características singulares no gênero, como fruto (Figura 1M) com sementes unisseriadas na base (Figura 1N) e sementes plurisseriadas no ápice (Figura 1O), como descritas para a seção Fissendocarpa. Apresenta semelhanças com $L$. erecta e L. octovalvis, principalmente após herborização. Entretanto, L. erecta produz frutos 4angulares, oblongoides, não alados (Figura 1I) e sementes elipsoides, não envolvidas pelo endocarpo (Figura 1J), enquanto L. octovalvis produz frutos cilíndricos a subcilíndricos (Figura 1Y) e sementes globosas, não envolvidas pelo endocarpo (Figura 1Z), também descritas em Sousa et al. (2019).
Ludwigia sect. Heterophylla Ramamoorthy, Ann. Missouri Bot. Gard. 66: 895. 1980.

Caules cilíndricos, prostrados com raízes nodais fibrosas, os flutuantes fixos ou submersos, geralmente inflados e esponjosos, sem pneumatóforos, subcilíndricos, com raízes nodais fibrosas. Folhas dimórficas, as distais são alternas ou dispostas em espiral e as basais submersas são verticiladas, com margens inteiras. Corola amarela. Possuem espécimes isostêmones e diplostêmones. Cápsulas 4-angulares, obcônicas, com paredes espessas, irregularmente deiscentes. Sementes plurisseriadas, não envolvidas pelo endocarpo; rafe com camada corticosa exposta (Figura 1P). Número cromossômico: $\mathrm{n}=8$.

Esta seção é representada somente por L. inclinata.

\subsection{Ludwigia inclinata (L.f.) M.Gómez, Anales Soc.} Esp. Hist. Nat. 23: 66. 1894.

Figuras 1P e 10; Munz (1947: figs 2 e 3), Ramamoorthy \& Zardini (1987: fig. 50) e Zardini \& Raven (1997: fig. 8).

Ervas, anuais, prostradas a flutuantes fixas e submersas; caules prostrados bem ramificados, glabros, os flutuantes fixos ou submersos, ramificados, glabros. Folhas com lâmina 1,6-12,4 × 0,8-3,8 cm, verde a verde-avermelhada em ambas as faces, glabra, dimórfica, as emersas alternas ou dispostas em espiral, oblanceolada a oboval, as imersas verticiladas, oblanceolada a estreitamente oblanceolada, membranácea, ápice agudo a obtuso, base aguda; pecíolo até 2,2 cm compr. (ou folhas sésseis); estípula 3-4 mm compr. Flores 4-meras, 14-17 cm compr.; sépalas 8-10 × 4-7 mm, verdes a verdeavermelhadas em ambas as faces, glabras, lanceoladas, ápice agudo a obtuso; pétalas 1,2-1,4 × 1,3-1,5 cm, obovais, ápice arredondado, emarginado; estames desiguais, filetes e anteras eretos; nectário convexo, ápice plano; estigma globoso. Cápsulas 1,1-2 cm × 3-7 mm, verdes a verde-avermelhadas, glabras; pedicelo 1,2-3,9 cm compr.; bractéola inconspícua na base dos frutos. Sementes ca. $3 \times 1 \mathrm{~mm}$, amarelo-acastanhadas, elipsoides, rafe proeminente, comprimento aproximadamente igual ao das sementes.

Amplamente distribuída no Brasil, ocorre na Amazônia, Caatinga, Cerrado e Pantanal, nos estados do Amapá, Amazonas, Bahia, Goiás, Maranhão, Mato Grosso, Mato Grosso do Sul, Minas Gerais, Pará e Roraima (Zeferino et al. 2020). D2, D4, D5 e G4: região ocidental do Chapadão Baiano e Vale do Rio São Francisco (Figura 10), em caatingas (s.str.) herbáceas a arbóreas e cerrados (s.l.), em ambientes úmidos e alagados, nas margens e leito dos rios, em solos arenosos. Coletada com flores e frutos entre março e junho.

Material selecionado - Barra, praia Cabeça de Touro, $11^{\circ} 05^{\prime} \mathrm{S}$, 4309'W, 400 m s.n.m., 4 jun. 1989 (fr.), H.P. Batista 1482 (HRB); Formosa do Rio Preto, $9 \mathrm{~km}$ na estrada p/localidade de Mato Grosso a partir da rodoviária, lagoa ao lado da estrada, $11^{\circ} 02^{\prime} \mathrm{S}, 45^{\circ} 15^{\prime} \mathrm{W}$, 540 m s.n.m., 30 mar. 2000 (fl., fr.), M.E.B. Silva et al. 353 (HRB, HUEFS, HUNEB, UESC); Irecê, Gentio do Ouro, Dunas do São 
Francisco, $11^{\circ} 25^{\prime} \mathrm{S}, 42^{\circ} 30^{\prime} \mathrm{W}$, maio 2000 (fr.), E.M. Silva 19 (ALCB); Malhada, rodovia para o Distrito de Cana Brava, 3,5 km ao $\mathrm{S}$ da cidade, áreas alagadiças dos baixadões do rio São Francisco, $14^{\circ} 21^{\prime}$ S, $43^{\circ} 45^{\prime}$ W, 450 m s.n.m., 2 abr. 2001 (fl., fr.), J.G. Jardim et al. 3384 (ALCB, CEPEC, HRB, HUEFS, HUNEB, HURB, NY*, SPF, UESC).

Ludwigia inclinata diferencia-se das demais espécies congêneres por apresentar folhas dimórficas, as distais são alternas ou dispostas em espiral no ápice do ramo, já as basais submersas são verticiladas, daí o nome da seção Heterophylla (Raven \& Tai 1979). Possui folhas com glândulas translúcidas, espessas e brilhantes, e pecíolo achatado (Rodrigues et al. 2007). Podem ser isostêmones ou diplostêmones (Raven \& Tai 1979).

Ludwigia sect. Humboldtia Ramamoorthy, Ann. Missouri Bot. Gard. 66: 895. 1980.

Caules cilíndricos, prostrados com raízes nodais fibrosas, os flutuantes fixos, com raízes nodais fibrosas e raros pneumatóforos brancos. Folhas alternas, rômbico-ovaladas, margens crenado-serrilhadas na metade superior e inteiras na metade inferior, geralmente com pecíolo longo, agrupadas em uma roseta distal na superfície da água. Corola amarela; androceu diplostêmone. Cápsulas 4-angulares, obcônicas, com paredes finas, irregularmente deiscentes. Sementes plurisseriadas, não envolvidas pelo endocarpo; rafe inconspícua (Figura 1H). Número cromossômico: $\mathrm{n}=8$.

Esta seção é representada somente por L. sedoides.

\subsection{Ludwigia sedoides (Bonpl.) H.Hara, J. Jap. Bot. 28:} 294. 1953.

Figuras 1HH e 14; Munz (1947: fig. 1), Ramamoorthy \& Zardini (1987: fig. 52), Zardini \& Raven (1997: fig. 17) e Wagner (2007: fig. 5).

Ervas, anuais a perenes, prostradas a flutuantes fixas; caules pouco ramificados, folhas agrupadas em rosetas nas extremidades dos ramos, glabros. Folhas com lâmina $0,8-1,6 \mathrm{~cm} \times 5-9 \mathrm{~mm}$, face adaxial verde brilhante a verde-avermelhada, a abaxial verdeavermelhada, rômbico-ovalada, ambas as extremidades agudas, glabra, membranácea; pecíolo 1,6-7,3 $\mathrm{mm}$ compr.; estípula 3-4 mm compr. Flores 4-meras, 2,5-3 cm compr.; sépalas 6-9,5 × 4-5,4 mm, face adaxial verde, a abaxial verde a verde-avermelhada, obovais, ápice agudo; pétalas 1,1-1,4 × 0,8-1,2 cm, obovais, ápice arredondado, emarginado; estames subiguais, filetes curtos, curvados, anteras curvadas, aproximandose das pétalas, ou às vezes desiguais, quase eretos, em indivíduos com flores maiores; nectário convexo, ápice plano; estigma depresso-globoso. Cápsulas $0,8-1,2 \mathrm{~cm}$ $\times$ 3-4 mm, verdes a verde-avermelhadas, glabras; pedicelo 2,4-3,6 cm compr.; bractéola 4-6 mm compr. Sementes ca. $7 \times 3 \mathrm{~mm}$, amarelo-acastanhadas, oblongoides, levemente falciformes.

No Brasil, ocorre nos domínios fitogeográficos da Amazônia, Cerrado, Mata Atlântica, nas Regiões Norte, Nordeste, Centro-Oeste, Sudeste e Sul, em 15 estados, além da Bahia (Zeferino et al. 2020). D2 e D5: região ocidental do Chapadão Baiano e no Vale do Rio São Francisco (Figura 14), em áreas alagadiças, margens e leito dos rios, sobre solos arenosos, em caatingas (s.str.) herbáceas a arbóreas e cerrados (s.1.). Coletada com flores e frutos em abril.

Material selecionado - s.l., s.d., J.S. Blanchet $3147\left(\mathrm{P}^{*}\right)$; Formosa do Rio Preto, Arroz de Baixo, ca. $11 \mathrm{~km}$ da cidade, fazenda do Sr. Júlio, brejo perto do Rio Preto, $11^{\circ} 03^{\prime} \mathrm{S}, 45^{\circ} 16^{\prime} \mathrm{W}, 531 \mathrm{~m}$ s.n.m., 4 abr. 2000 (fl., fr.), R.P. Oliveira et al. 498 (CEPEC, HRB, HUEFS, HUNEB); Gentio do Ouro, $27 \mathrm{~km}$ de Xique-Xique,

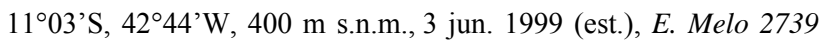
(CEN*, HUEFS).

Ludwigia sedoides é a única espécie do gênero com folhas rômbico-ovaladas, margens crenado-serrilhadas na metade superior e inteiras na inferior, geralmente com pecíolo longo.

Ludwigia sect. Jussiaea (L.) Hoch, W.L.Wagner \& P.H.Raven, PhytoKeys 50: 33. 2015.

Caules cilíndricos, os prostrados e os flutuantes fixos, com raízes nodais fibrosas e raros pneumatóforos brancos, esponjosos, os flutuantes livres, com raras raízes nodais fibrosas, abundantes pneumatóforos brancos e esponjosos, quando eretos, subcilíndricos, geralmente com base e raízes esponjosas, esbranquiçadas. Folhas alternas com margens inteiras. Corola amarela, amarelo-clara ou branca com mácula amarela; androceu diplostêmone ou isostêmone. Cápsulas levemente 5-angulares, subcilíndricas ou oblongoides, torulosas, lenhosas, com paredes grossas, tardiamente deiscentes, com a superfície marcada pelas divisões internas das sementes, unisseriadas em cada lóculo, envolvidas totalmente pelo endocarpo truncado e lenhoso; rafe inconspícua. Número cromossômico: $n$ $=8$.

No estado da Bahia, está representada por $L$. helminthorrhiza, L. peploides e L. torulosa.

\subsection{Ludwigia helminthorrhiza (Mart.) H.Hara, J. Jap.} Bot. 28: 292. 1953.

Figuras 1K, L, 3A, B e 8; Munz (1947: fig. 34) e Cumana Campos (2010: fig. 4).

Ervas, anuais a perenes, prostradas a flutuantes fixas ou livres; caules ramificados, cilíndricos, glabros, os prostrados bem ramificados, raízes nodais fibrosas, os flutuantes livres, ramificados, raras raízes nodais fibrosas, abundantes pneumatóforos brancos e esponjosos. Folhas com lâmina 1,7-5,6 × 1,5-4,2 cm, face adaxial verde brilhante a verde-avermelhada e a abaxial verde, glabra, elíptica com as extremidades agudas ou orbicular a oboval com ápice agudo a arredondado, base arredondada, decorrente, membranácea; pecíolo 4-7 $\mathrm{mm}$ compr.; estípula 1-2 mm compr. Flores 5-meras, ca. 2,8 cm compr.; sépalas 4-8 $\times$ 2-4 mm, ambas as faces verdes a verdeavermelhadas, glabras, lanceoladas, ápice agudo; pétalas $1,2-1,5 \mathrm{~cm} \times 6-8 \mathrm{~mm}$, brancas com mácula amarela, obovais, ápice arredondado; estames desiguais, 
filetes e anteras eretos; nectário levemente convexo, ápice plano; estigma capitado. Cápsulas 1,1-2,9 cm $\times$ 2-4 mm, verdes, verde-avermelhadas a verde-vináceas, levemente 5-angulares, subcilíndricas, glabrescentes a glabras; pedicelo 1,3-4,2 cm compr.; bractéola inconspícua na base do fruto. Sementes ca. $2 \times 1 \mathrm{~mm}$, translúcidas, oblongo-ovoides.

No Brasil, ocorre nos domínios fitogeográficos da Amazônia, Caatinga e Pantanal, no Amazonas, Amapá, Ceará, Maranhão, Mato Grosso, Mato Grosso do Sul, Pará, Paraíba, Rio Grande do Norte e Rondônia, além da Bahia (Zeferino et al. 2020). C8, D4, D10, E9, F3, F4 e G4: áreas alagadiças no Vale do Rio São Francisco, na transição entre Cerrado e Caatinga (Figura 8), em caatingas (s.str.) e cerrados (s.l.) herbáceos a arbóreos, florestas ombrófilas (= pluviais) na região litorânea, em matas ciliares, nas margens e leito de rios moderadamente antropizados, em solos arenosos a argilosos. Coletada com flores e frutos entre janeiro a maio.

Material selecionado - Bom Jesus da Lapa, $32 \mathrm{~km}$ da cidade, a NE de Caldeirão, acima da bacia do rio São Francisco, $13^{\circ} 07^{\prime} \mathrm{S}$,

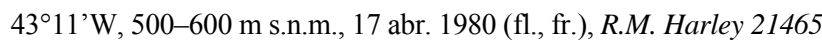
(CEPEC, NY*, P*, SPF, US*); Camaçari, sítio Encantado, Abrantes, na BA-234, $12^{\circ} 48^{\prime} \mathrm{S}, 38^{\circ} 18^{\prime} \mathrm{W}, 17$ mar. 2007 (fl., fr.), M.L. Guedes et al. s.n. (ALCB 76764); Carinhanha, Médio São Francisco, foz do rio Carinhanha, $14^{\circ} 18^{\prime}$ S, $43^{\circ} 48^{\prime} \mathrm{W}, 478$ m s.n.m., 26 maio 2007 (fl., fr.), M.L. Guedes et al. 14138 (ALCB); Conde, BA-099, margem do Rio das Pedras, $1^{\circ} 50^{\prime}$ 'S, $37^{\circ} 38^{\prime} \mathrm{W}, 12$ m s.n.m., 24 fev. 2019 (fl., fr.), N.X.M. Sousa et al. 571 (HURB, MAC, UEC); Itiúba, Lagoa da Eugenia, próximo de Camaleão, $10^{\circ} 40^{\prime} \mathrm{S}, 39^{\circ} 43^{\prime} \mathrm{W}, 300$ m s.n.m., 21 fev. 1974 (fl., fr.), R.M. Harley 16276 (CEPEC, NY*, US*); Malhada, rodovia para o Distrito de Cana Brava, 3,5 km ao sul da cidade, áreas alagadiças dos Baixadões do Rio São Francisco, $14^{\circ} 21^{\prime} \mathrm{S}, 43^{\circ} 45^{\prime} \mathrm{W}$, 450 m s.n.m., 2 abr. 2001 (fl., fr.), J.G. Jardim et al. 3385 (ALCB, HRB, HUEFS, HUNEB, NY*); Morpará, Lagoa Grande, $11^{\circ} 33^{\prime} \mathrm{S}$,

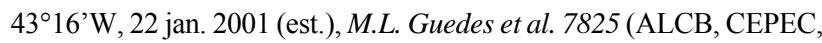
HUEFS, UESC); Pilão Arcado, Dourados, Lagoa do Jatobá, 12 nov. 2009 (est.), A.P. Prata et al. 1998 (ASE*).

Ludwigia helminthorrhiza se distingue das demais espécies congêneres da Bahia pelas raízes nodais fibrosas, pneumatóforos brancos e esponjosos em abundância e flores de corola branca com mácula amarela (Figura 3A, B). Os ramos flutuantes fixos apresentam raízes nodais fibrosas e pneumatóforos brancos, folhas obovais a orbiculares, verdes, brilhantes a verde-avermelhadas na face adaxial, com ápice agudo a arredondado e base arredondada a levemente decorrente. Os ramos livres apresentam abundantes pneumatóforos brancos, folhas obovais a orbiculares, sobrepostas, face adaxial verde, brilhante, com ápice arredondado e base arredondada a decorrente. Os abundantes pneumatóforos e a sobreposição foliar auxiliam a flutuação e sua identificação quando estéril, mesmo em material herborizado. Ramos prostrados com raízes nodais fibrosas, folhas elípticas, mais espaçadas, com ambas as extremidades agudas, face adaxial verde a verde-avermelhada, a abaxial verde, sépalas com ambas as faces verdes a verde-avermelhadas e frutos verdes a verde-avermelhados (Figura 1K). À medida que diminui a vazão de água no rio ou em um tanque, os frutos ficam com as paredes mais grossas e lenhosas, apresentando deiscência tardia e sementes unisseriadas envolvidas totalmente pelo endocarpo truncado e lenhoso (Figura 1L).

\subsection{Ludwigia peploides (Kunth) P.H.Raven, Reinwardtia} 6: 393.1964.

Figuras 1AA, BB, 4C e 13; Munz (1947: fig. 38) e Cumana Campos (2010: fig. 9).

Ervas, anuais, prostradas a flutuantes fixas; caules ramificados, cilíndricos, glabros, os prostrados bem ramificados, com raízes nodais fibrosas, os flutuantes fixos, ramificados, com raízes nodais fibrosas e raros pneumatóforos brancos, esponjosos. Folhas com lâmina $1-6,5 \times 0,5-2 \mathrm{~cm}$, face adaxial verde a verdeavermelhada, a abaxial verde, glabra, oboval, oblonga, oblanceolada e lanceolada, membranácea, ápice arredondado a obtuso, base acuminada; pecíolo 4-25 mm compr.; estípula 1-2 mm compr. Flores 5-meras, 1,6-3 cm compr.; sépalas 4-12 × 1,5-3 mm, face adaxial verde, a abaxial verde a verde-avermelhada, glabras, linear-lanceoladas, ápice agudo; pétalas 0,7-1,4 $\times$ ca. $1 \mathrm{~cm}$, amarelas, obovais, ápice arredondado; estames desiguais, filetes e anteras eretos; nectário levemente convexo, ápice plano; estigma truncado. Cápsulas $1,4-2,8 \mathrm{~cm} \times 2-5 \mathrm{~mm}$, verdes a verdeavermelhadas, levemente 5-angulares, subcilíndricas, glabras; pedicelo 0,4-2,9 cm compr.; bractéola inconspícua a 0,5-1 $\mathrm{mm}$ compr., na base do fruto. Sementes ca. $3 \times 2 \mathrm{~mm}$, translúcidas, depresso-ovaladas.

No Brasil, apresenta ocorrência nos domínios fitogeográficos da Caatinga, Cerrado e Mata Atlântica, nos estados de Alagoas, Rio Grande do Sul e Santa Catarina (Zeferino et al. 2020) e na Bahia (Sousa et al. 2019). B7, C9, D7, D8, D10, E6, E8, E9, F4, F6, F7, G5 e G8: Caatinga, Cerrado e Mata Atlântica (Figura 13), em regiões semiáridas, em formações florestais, savânica e de restinga, associadas a matas ciliares, nas margens e leito de ambientes aquáticos permanentes ou temporários, limpos a moderadamente antropizados, em brejos, lagos, rios, riachos e cachoeiras, em solos arenosos, siltosos e argilosos. Coletada com flores e frutos em todos os meses do ano.

Material selecionado - Abaíra, Engenho de Baixo, 13ำ' $9^{\prime}$,

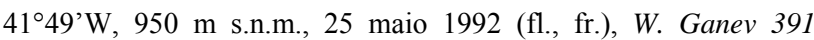
(HUEFS, SPF); Anguera, Lagoa 5, $12^{\circ} 11^{\prime} \mathrm{S}, 39^{\circ} 09^{\prime} \mathrm{W}, 130 \mathrm{~m}$ s.n.m., 18 ago. 1996 (fl., fr.), F. França et al. 1761 (CEPEC, HUEFS, $\mathrm{MBM}^{*}, \mathrm{SP}$ ); Baixa grande, próximo à entrada da cidade, lagoa temporária ao lado da estrada, $11^{\circ} 57^{\prime} \mathrm{S}, 40^{\circ} 11^{\prime} \mathrm{W}, 356,5 \mathrm{~m}$ ms.n.m., 15 jul. 2018 (fl., fr.), N.X.M. Sousa et al. 505 (HURB); Bom Jesus da Lapa, próximo à igreja Nossa Senhora dos Navegantes, rio São Francisco, 5 mar. 2019 (fl., fr.), N.X.M. Sousa et al. 595 (HURB); Boninal, margens do rio Cochó, próximo à ponte da estrada Boninalpovoado Caititu, 25 abr. 2014 (fl., fr.), N.X.M. Sousa 12 (HURB); Cabaceiras do Paraguaçu, BA-491, lado direito, lago Garora, perto do Haras Manga Larga, 12³7’S, 3857’W, 7 ago. 2012 (fl., fr.), L.Y.S. Aona et al. 1548 (HURB); Cachoeira, vale dos rios Paraguaçu 
e Jacuípe, porto Castro Alves, $12^{\circ} 32^{\prime}$ 'S, 3905’W, 40-120 m s.n.m., nov. 1980 (fl., fr.), Grupo Pedra do Cavalo 904 (ALCB, HUEFS); Camaçari, Guarajuba, condomínio Recanto do Sol, 1441'S, 3806’W, 5 jun. 2011 (fl., fr.), M.L. Guedes et al. 18187 (ALCB); Candeias, fazenda Lagoa Azul (Sr. Etevaldo), BR-324, Km 40, $12^{\circ} 38^{\prime}$ S, 38 $28^{\circ} \mathrm{W}, 23$ set. 2004 (fl., fr.), K.R.B. Leite et al. 445 (HUEFS); Castro Alves, próximo à estrada de ferro, terreno brejoso, $12^{\circ} 43^{\prime}$ 'S, 39²3'W, 223 m s.n.m., 22 jul. 2015 (fl., fr.), N.X.M. Sousa 141 (HUEFS, HURB); Conceição do Coité, área de brejo na rodovia, 30 jul. 2017, (fl., fr.), G. Costa 2632 (HURB); Conde, BA-099, margem do Rio das Pedras, $11^{\circ} 50^{\prime}$ 'S, 37³8'W, 12 m s.n.m., 24 fev. 2019 (fl., fr.), N.X.M. Sousa et al. 570 (HURB); Cruz das Almas, fazenda Campo Limpo, terrenos encharcados e lagoas, mar. 1958 (fl., fr.), R.P. Lordêlo 58-6 (ALCB); Curaçá, riacho permanente, 25 nov. 2009 (fl., fr.), M. Oliveira 4513 (HVASF); Dom Macedo Costa, primeira entrada à esquerda antes da cidade, lagoa, 10 fev. 2015 (fl., fr.), G. Costa et al. 1220 (HUEFS, HURB); Feira de Santana, Lagoa 2, Km 3, BA-052, 12¹6'S, 39³’W, 108 m s.n.m., 18 ago. 1996, (fl., fr.), F. França et al. 1757 (CEPEC, HUEFS, SP); Ilhéus, estrada Itabuna-Ilhéus, fazenda Primavera, $1 \mathrm{~km} \mathrm{E} \mathrm{do} \mathrm{CEPLAC,} 9$ fev. 1985 (fl., fr.), E. Zardini et al. 2238 (CEPEC); Itabuna, bairro São Caetano, margem do ribeirão, 9 nov. 1981 (fl., fr.), T.S. Santos et al. 3686 (CEPEC, HRB); Jequié, fazenda Beira Rio, do Prof. Elzo, às margens do rio de Contas, $13^{\circ} 53^{\prime} \mathrm{S}, 40^{\circ} 03^{\prime} \mathrm{W}, 208,5 \mathrm{~m}$ s.n.m., 1 mar. 2018 (fl., fr.), N.X.M. Sousa et al. 278 (ALCB, HURB); Juazeiro, vila Tiradentes, Caatinga, 2 jan. 2010 (fl., fr.), Chagas-Mota 6652 (MAC); Jussiape, ca. $5 \mathrm{~km}$ a sudoeste de Jussiape, no Rio de Contas, na rodovia

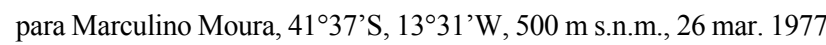
(fl., fr.), R.M. Harley et al. 20021 (CEPEC, NY*, SPF, UEC); Lagoa Real, povoado Tapera, na margem do rio São João, $14^{\circ} 14^{\prime} \mathrm{S}, 42^{\circ} 15^{\prime} \mathrm{W}$, 545,5 m s.n.m., 4 mar. 2019 (fl., fr.), N.X.M. Sousa et al. 581 (HURB); Livramento de Nossa Senhora, povoado Tabuleiro, às margens do

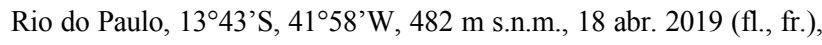
N.X.M. Sousa et al. 619 (HURB); Maracás, sudoeste, margem do Rio de Contas, onde a Embasa faz a captação, $13^{\circ} 26^{\prime} \mathrm{S}, 40^{\circ} 25^{\prime} \mathrm{W}, 23$ out. 2012 (fl., fr.), M.L. Guedes et al. 20191 (ALCB); Morro do Chapéu, Represa Angelin, entroncamento para Ventura, $11^{\circ} 38^{\prime} \mathrm{S}, 40^{\circ} 56^{\prime} \mathrm{W}, 689$ m s.n.m., 7 set. 2006 (fl., fr.), J.L. Ferreira et al. 30 (HUEFS); Muniz Ferreira, rio embaixo da ponte, 11 abr. 2018 (fl., fr.), G.V. Fonseca et al. 175 (HURB); Piritiba, 11 ${ }^{\circ} 43^{\prime} \mathrm{S}, 40^{\circ} 33^{\prime} \mathrm{W}, 30$ maio 1980 (fl., fr.), L.R. Noblick 1879 (ALCB, CEPEC, HUEFS, HRB); Ribeira do Pombal, fazenda Salgadinho, $8 \mathrm{~km}$ sul da cidade, na BR-101, 10 50 'S 38³3’W, 1 mar. 1984 (fl., fr.), L.R. Noblick 2956 (HUEFS); Rio de Contas, às margens do rio Brumado, dentro de Rio de Contas, próximo à ponte, $1^{\circ} 58^{\prime} \mathrm{S}, 4^{\circ} 81^{\prime} \mathrm{W}, 1.037 \mathrm{~m}$ s.n.m., 20 ago. 2016 (fl., fr.), N.X.M. Sousa 201 (HURB); Sapeaçu, fazenda Sapezinho, Brejo de Santinho, 20 nov. 2018 (fl., fr.), W.O. Fonseca 615 (HURB); Serra Preta, $7 \mathrm{~km} \mathrm{~W}$ do Ponto de Serra Preta, fazenda Santa Clara, $12^{\circ} 10^{\prime} \mathrm{S}$, 39²0’W, 17 jul. 1985 (fl., fr.), L.R. Noblik et al. 4137 (ALCB, HUEFS).

Ludwigia peploides apresenta folhas lanceoladas a oblanceoladas quando prostrada (Figura 4C) e folhas obovais a oblongas quando flutuante fixa. Possui corola amarela, 5-mera (Figura 4C) e frutos subcilíndricos, verdes a verde-avermelhados (Figura 1AA), marcados pelas divisões internas das sementes envolvidas totalmente pelo endocarpo obliquo-truncado, lenhoso e resistente (Figura 1BB). Esta espécie apresentou maior propagação vegetativa nos períodos chuvosos e, frequentemente, com maior produção de frutos quando se inicia a escassez de água (Sousa et al. 2019).

\subsection{Ludwigia torulosa (Arn.) H.Hara, J. Jap. Bot. 28:} 294. 1953.

Figuras 1MM-OO, 4H e 15; Munz (1947: fig. 39) e Lovo \& Zappi (2018: fig. 3G, H).

Ervas a subarbustos, anuais, eretos, 0,8-1,6 m alt.; caules ramificados, subcilíndricos, geralmente com base esponjosa, glabros, com raízes laterais fibrosas e raras esponjosas, esbranquiçadas. Folhas com lâmina 4-11,5 $\mathrm{cm} \times 1-3 \mathrm{~mm}$, face adaxial verde a verde-avermelhada, a abaxial verde, glabra, lanceolada a linear-lanceolada, cartácea, ápice acuminado a agudo, base aguda; pecíolo 0,5-3 mm compr. (ou folhas sésseis); estípula 1-4 mm compr. Flores 5(6)-meras, 1-1,3 cm × 1-2 mm; sépalas $3,5-5 \times 1,2-1,4 \mathrm{~mm}$, face adaxial verde, a abaxial verde a verde-avermelhada, glabras, lanceoladas, ápice agudo; pétalas ca. 7,5 × 1-1,5 mm, amarelo-claras, linearlanceoladas, ápice acuminado; 5(6) estames epipétalos, iguais; nectário subcircular, plano; estigma subcapitado a capitado. Cápsulas $0,6-1 \mathrm{~cm} \times 2-4 \mathrm{~mm}$, verdes a verde-avermelhadas, oblongoides, torulosa, com 2 ou 3 protuberâncias laterais, glabras; pedicelo 2,7-8 $\mathrm{mm}$ compr.; bractéola inconspícua, na base dos frutos. Sementes ca. $2 \times 1 \mathrm{~mm}$, translúcidas a castanho-claras, elíptico-globosas.

No Brasil, ocorre nos domínios fitogeográficos da Amazônia e Mata Atlântica, no Amapá, Minas Gerais, Pará, Paraná e Roraima (Zeferino et al. 2020), sendo este o primeiro registro para a Bahia. F5: restinga na Mesorregião do Sul Baiano (Figura 15), em florestas e campos de várzea, ambientes com regimes de inundações periódicas que acumulam e represam águas pluviais, geralmente no leito de brejos e lagos, em solos arenosos. Coletada com flores e frutos em abril e novembro.

Material selecionado - Belmonte, $\mathrm{Km} 1$ da rodovia BelmonteItapebi, brejo, 17 abr. 1975 (fl., fr.), T.S. Santos 2987 (CEPEC); Valença, Guaibim, Área de Proteção Permanente, 9 nov. 2018 (fl., fr.), G.V. Fonseca et al. 398 (HURB).

Material adicional selecionado - BRASIL. MINAS GERAIS: Caratinga, Lagoa Silvana, em ilhas flutuantes a $3 \mathrm{~m}$ da margem da lagoa, local com muita luminosidade, 4 jan. 2002 (fl., fr.), M.O.D. Pivari et al. 74 (ESA, SPF). PARÁ: Almeirim, monte Dourado, Estação Ecológica do Jari (SEMA), beira de lago, $00^{\circ} 32^{\prime} \mathrm{S}, 52^{\circ} 51^{\prime} \mathrm{W}$, 12 nov. 1986 (fl., fr.), M.J. Pires et al. 1442 (K*, NY*). PARANÁ: fazenda Lagoa, sul do rio Ivaí, ca. $15 \mathrm{~km}$ E de São Tomé, 6 abr. 1966 (fl., fr.), J.C. Lindeman et al. 941 (K*, MBM*, NY*).

Ludwigia torulosa pode ser facilmente reconhecida pelos caules com a base submersa esponjosa, flores menores na axila dos ramos laterais (Figura $4 \mathrm{H}$ ), isostêmones, com 5 ou 6 estames epipétalos iguais, nectário subcircular, plano (Figura $1 \mathrm{NN}$ ), cápsulas torulosas, glabras, verdes, fortemente marcadas pelas sementes envolvidas em segmentos lenhosos do endocarpo (Figura 1OO), principalmente quando maduras ou secas, marrons, arredondadas, lateralmente com 2 ou 3 protuberâncias (Figura 1MM). 
Ludwigia sect. Macrocarpon (Micheli) H.Hara, J. Jap. Bot. 28: 291. 1953.

Caules subcilíndricos a cilíndricos, eretos, com raízes laterais fibrosas e raros pneumatóforos brancos. Folhas alternas com margens inteiras. Corola amarela; androceu diplostêmone. Cápsulas cilíndricas a subcilíndricas, com paredes finas, irregularmente deiscentes. Sementes plurisseriadas não envolvidas pelo endocarpo; rafe sem camada corticosa exposta. Números cromossômicos: $\mathrm{n}=8,16$ e 24 . Bahia.

Representada somente por L. octovalvis no estado da

\subsection{Ludwigia octovalvis (Jacq.) P.H.Raven, Kew Bull.} 15: 476. 1962.

Figuras 1Y, Z, 4A, B e 12; Munz (1947: figs 23-26), Zardini \& Raven (199: fig. 147), Wagner (2007: fig. 6) e Lovo \& Zappi (2018: fig. 3E, F).

Nomes populares: pimenta-d'água, beladona-dosgerais, corticeiro, mato-pacu.

Ervas a arbustos, anuais, eretos, 0,3-2,9 m alt.; caules muito ramificados, pilosos, pubescentes, glabrescentes a glabros, extremidade dos ramos densamente pilosos a pubescentes, esbranquiçados. Folhas com lâmina 2,6-12,3 × 0,4-3 cm, face adaxial verde a verde-avermelhada, glabrescente a glabra, a abaxial verde, pilosa, pubescente a glabra, oblonga, oval-lanceolada, lanceolada, linear-lanceolada a linear, membranácea, ápice acuminado a agudo, base arredondada, atenuada a obtusa; pecíolo 1-4 mm compr. (ou folhas sésseis); estípula 1-3 mm compr. Flores 4(5)-meras, 2-3,4 cm compr.; sépalas 5-13 ×5-6 mm, face adaxial verde a verde-avermelhada, glabrescente a glabra, a abaxial verde, pubescente a glabra, ovais a lanceoladas, ápice agudo a acuminado; pétalas 1-1,6× 0,9-1,3 cm, obovais ou orbiculares, ápice arredondado, emarginado; estames desiguais, filetes e anteras eretos; nectário convexo, ápice plano; estigma subcapitado a capitado. Cápsulas $0,9-18,3 \mathrm{~cm} \times 2-4 \mathrm{~mm}$, verdes, verde-avermelhadas a verde-vináceas, cilíndricas a subcilíndricas, pubérulas, pilosas a glabrescentes; pedicelo 0,1-2 cm compr.; bractéola inconspícua, na base dos frutos. Sementes ca. $8 \times 3 \mathrm{~mm}$, globosas, amarelo-acastanhadas a castanho-avermelhadas, não envolvidas pelo endocarpo; rafe expandida, sem camada corticosa exposta, comprimento igual ao das sementes.

Amplamente distribuída no Brasil, ocorre em praticamente todos os estados (Zeferino et al. 2020). B5, B7, B9, C6, C7, D4, D5/6, D7, D8, D9, D10, E5, E6, E7, E8, E9/10, F3, F4, F6, F8, F9, G4, G5, G6, G7, G8, H8, I8/9 e K8: Caatinga, Cerrado e Mata Atlântica (Figura 12), associada a matas ciliares, nas margens e leito de ambientes aquáticos permanentes ou temporários, como brejos, lagos, rios, riachos e cachoeiras, em solos arenosos, siltosos e argilosos. Sendo encontrada desde ambientes limpos até moderada a intensamente antropizados. Coletada com flores e frutos em todos os meses do ano.
Material selecionado - Abaíra, Brejo do Engenho, $13^{\circ} 18^{\prime} \mathrm{S}$, 41 ${ }^{\circ} 48^{\prime}$ W, 950-1000 m s.n.m., 27 dez. 1992, D.J.N. Hind et al. 50453 (CEPEC, HUEFS, NY*, SPF); Alagoinhas, povoado Catuzinho, fazenda Pimentel, Lagoa de Dona Maria, 6 set. 2008 (fl., fr.), N.G. Jesus et al. 2301a (HUNEB); Amélia Rodrigues, Bairro do Orabolas, trilha que vai para a fonte, entrando duas ruas antes do antigo clube Orabolas, Reserva de Mata Atlântica, 10 abr. 2016 (fl., fr.), J.F.C. Oliveira 75 (HUEFS); Andaraí, estrada BA-145, margens do rio Santo Antônio, 13 ago. 2016 (fl., fr.), N.X.M. Sousa 147 (ALCB, HURB); Anguera, BA-052, Estrada do feijão, sentido Anguera-Ipirá, lagoa temporária ao lado da estrada, 13 jul. 2018 (fl., fr.), N.X.M. Sousa et al. 501 (HURB); Aramari, represa do rio Aramari, 11 dez. 2009 (fl., fr.), I.M.O. Carvalho 28 (HUNEB); Baixa grande, próximo à entrada da cidade, lagoa temporária ao lado da

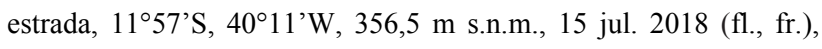
N.X.M. Sousa et al. 506 (HURB); Barra do Mendes, povoado São Bento, $11^{\circ} 48^{\prime} \mathrm{S}, 42^{\circ} 05^{\prime} \mathrm{W}, 720$ m s.n.m., 25 out. 2009 (fl., fr.), E. Melo et al. 6839 (HUEFS); Boa Nova, Parque Nacional de Boa Nova, Lajedo dos beija-flores, $14^{\circ} 19^{\prime} \mathrm{S}, 40^{\circ} 15^{\prime} \mathrm{W}, 900$ m s.n.m., 27 out. 2017 (fr.), G. Costa et al. 2906 (HURB); Boninal, margens do rio Cochó, próximo à ponte da estrada Boninal-povoado Caititu, 25 abr. 2014 (fl., fr.), N.X.M. Sousa 14 (ALCB, HUEFS, HURB); Brotas de Macaúbas, 23 dez. 1995 (fl., fr.), M.P. Silva et al. 4 (ALCB); Brumado, estrada Itaquaraí-Iguatemi, às margens do rio São João, 1358'S, 4146'W, 406,5 m s.n.m., 20 abr. 2019 (fl., fr.), N.X.M. Sousa et al. 637 (HURB); Cabaceiras do Paraguaçu, BA-491, balsa, lado direito, lago Garora, perto do Haras Manga Larga, 12 ${ }^{\circ} 37^{\prime}$ S, 38 $57^{\circ} \mathrm{W}, 7$ ago. 2012 (fl., fr.), L.Y.S. Aona et al. 1549 (HURB); Cachoeira, vale dos rios Paraguaçu e Jacuipe, porto Castro Alves, $12^{\circ} 32^{\prime}$ 'S, 3905'W, 40-120 m s.n.m., maio 1980 (fl., fr.), Grupo Pedra do Cavalo 73 (ALCB, HUEFS, CEPEC); Cairu, ilha de Boipeba, APA Tinharé-Boipeba, 133'ㅇ, 3855'W, 50 m s.n.m., 3 jan. 2007, A.M. Amorim et al. 6801 (CEPEC, SPF); Caitité, Brejinho das Ametistas, Área da Bahia Mineração, $14^{\circ} 15^{\prime} \mathrm{S}$, 42³1'W, 845 m s.n.m., abr. 2008 (fr.), M.S. Mendes et al. 547 (HUEFS); Camacan, RPPN Serra Bonita, 9,7 km W de Camacan, na estrada para Jacareci, $15^{\circ} 23^{\prime} \mathrm{S}, 39^{\circ} 33^{\prime} \mathrm{W}, 800-900 \mathrm{~m}$ s.n.m., 22 jul. 2011 (fl., fr.), A.M. Amorim 8028 (CEPEC); Camaçari, Guarajuba, loteamento Canto do Mar, 1244'S, 3809'W, 22 nov. 1982 (fl., fr.), H.P. Bautista 1365 (ALCB, HRB); Campo Alegre de Lourdes, 26 maio 2002 (fl., fr.), A.M. Miranda et al. 3996 (HUEFS); Casa Nova, arredores da represa de Sobradinho, $09^{\circ} 21^{\prime}$ 'S, $40^{\circ} 47^{\prime} \mathrm{W}, 392 \mathrm{~m}$ s.n.m., 5 jul. 2009 (fl., fr.), J. Paula-Souza et al. 9819 (IAC); Castro Alves, brejo localizado à direita, $6 \mathrm{~km}$ após a fábrica de calçados de Castro Alves (sentido Sapeaçu), 12 ${ }^{\circ} 44^{\prime}$ S, 39 $9^{\circ} 24^{\prime} \mathrm{W}, 9$ out. 2013 (fl., fr.), L.Y.S. Aona et al. 3232 (HURB, HUEFS); Caturama, Caieira, 13ํำ' $43^{\circ} 13^{\prime} \mathrm{W}, 653$ m s.n.m., 5 jul. 2007 (fl., fr.), A.A. Conceição 2403 (HUEFS); Coaraci, BA-262, sentido Almadina, fazenda do lado esquerdo, após $5 \mathrm{~km}$ de Coaraci, 143'ㄱ' $\mathrm{S}, 39^{\circ} 33^{\prime} \mathrm{W}$, 188 m s.n.m., 13 nov. 2019 (fl., fr.), N.X.M. Sousa et al. 746 (HURB); Conceição de Feira, área alagada na base da Serra, saída para Feira de Santana, 5 set. 2012 (fl., fr.), G. Costa et al. 728 (HURB); Conceição do Almeida, 15 fev. 2012 (fr., fl.), G. Costa et al. 647 (UEC); Conceição do Coité, via vicinal que dá acesso ao distrito de Juazeirinho, 21 dez. 2014 (fl., fr.), G. Costa 1199 (HURB); Conde, BA-099, margem do rio Crumaí, $11^{\circ} 48^{\prime}$ S, 37³7’ W, 10 m s.n.m., 23 fev. 2019 (fl., fr.), N.X.M. Sousa et al. 562 (HURB); Condeúba, rodovia Jacaraci-Condeúba, margens ao lado da ponte do rio Gavião, $14^{\circ} 52^{\prime}$ S, $42^{\circ} 00^{\prime} \mathrm{W}, 631$ m s.n.m., 12 nov. 2019 (fl., fr.), N.X.M. Sousa 
et al. 739 (HURB); Contendas do Sincorá, lagoa e campo alagado próximo à sede da FLONA, $13^{\circ} 55^{\prime}$ 'S , 41 ${ }^{\circ} 06^{\prime} \mathrm{W}, 388 \mathrm{~m}$ s.n.m., 6 fev. 2015 (fl., fr.), L.Y.S. Aona et al. 3880b (HURB); Correntina, margem à esquerda no sentido da foz, Rio das Éguas, centro da cidade, $13^{\circ} 20^{\prime}$ S, $44^{\circ} 37^{\prime} \mathrm{W}, 561$ m s.n.m., 6 mar. 2019 (fl., fr.), N.X.M. Sousa et al. 598 (HURB); Cruz das Almas, loteamento Miradouro, área alagada, 26 nov. 2013 (fl., fr.), N.X.M. Sousa 7 (HURB, SPF); Entre Rios, fazenda Rio do Negro, $12^{\circ} 53^{\prime}$ 'S, 37 $57^{\circ}$ 'W, 153 m s.n.m., 26 maio 2007 (fr.), A.V. Popovkin et al. 5 (HUEFS); Esplanada, Baixio, região próxima ao manguezal, 28 jul. 2005 (fl., fr.), L.P. Virgens et al. 9 (HUEFS); Feira de Santana, rua Topázio, bairro Brasília, 12¹6'S; 3857'W, 238 m s.n.m., 4 out. 2019 (fl., fr.), L.P. Queiroz 16685 (HUEFS); Formosa do Rio Preto, margem esquerda do rio Preto, porto do campinho de areia, 8 jan. 2009 (fl., fr.), B.S. Gregório 69 (BRBA); Gandu, rodovia BA-120, do lado da ponte,

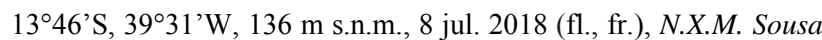
et al. 296 (HURB); Gongogi, 22 abr. 2010 (fl., fr.), H. Adorno s.n. (HST 17662); Governador Mangabeira, lagoa próxima a barragem Pedra do Cavalo, $12^{\circ} 33^{\prime}$ 'S, 3902'W, 149 m s.n.m., 18 set. 2016 (fr.), N.X.M. Sousa et al. 205 (HURB); Ibiassucê, a $2 \mathrm{~km}$ próximo da cidade, lago à direita da estrada, $14^{\circ} 15^{\prime} \mathrm{S}, 42^{\circ} 15^{\prime} \mathrm{W}, 542,5 \mathrm{~m}$ s.n.m., 4 mar. 2019 (fl., fr.), N.X.M. Sousa et al. 586 (HURB); Ibirapitanga, nas margens ao lado da ponte do rio Oricó, 15 nov. 2019 (fl., fr.), N.X.M. Sousa et al. 759 (HURB); Ilhéus, Ilhéus-Olivença, próximo ao hotel Praia do Sol, 21 nov. 2014 (fl., fr.), N.X.M. Sousa 43 (HURB); Itaberaba, BR-242, aproximadamente $15 \mathrm{~km}$ depois da sede, sentido Seabra, lado direito, numa lagoa, $12^{\circ} 30^{\prime} \mathrm{S}, 40^{\circ} 26^{\prime} \mathrm{W}$, 332,5 m s.n.m., 16 jun. 2018 (fl., fr.), N.X.M. Sousa et al. 327 (HURB); Itabuna, anel viário, 23 ago. 1996 (fl., fr.), A.L.B. Sartori et al. 230 (UEC); Itagibá, Litoral Sul, fazenda Campo Verde, $14^{\circ} 10^{\prime}$ 'S, 39 $39^{\circ} 3^{\prime} \mathrm{W}, 15$ set. 2008 (fl., fr.), C.E. Ramos et al. 327 (ALCB, US*); Itapé, margem do rio Cachoeira, próximo à ponte, $14^{\circ} 53^{\prime}$ 'S, 39 $9^{\circ} 10^{\prime}$ W, 3 m s.n.m., 23 maio 2009 (fl., fr.), E.A. Rocha et al. 1724 (CEPEC); Jacobina, Serra do Tombador, 11¹4'S, 4043’W, 910 m s.n.m., 31 mar. 1996 (fl., fr.), A.M. Giulietti et al. 2681 (HUEFS); Jaguaripe, areal Itapixacara, fazenda de carcinicultura do Sr. Júnior, $13^{\circ} 07^{\prime}$ S, 38 $38^{\circ} 58^{\prime} \mathrm{W}, 27$ ago. 2015 (fl., fr.), L.Y.S. Aona et al. 4193 (ASE*, FURB*, HUEFS, HURB, MAC); Jandaíra, BA-099, no Km 179, 23 fev. 2019 (fl., fr.), N.X.M. Sousa et al. 556 (HURB); Jequiriçá, Cachoeira dos Prazeres, trilha na Pousada do Vale, 6 nov. 2018 (fl., fr.), W.O. Fonseca et al. 589 (HUEFS, HURB); Juazeiro, Serra do Mulato, 0944'S, 4041'W, 28 mar. 2000 (fl., fr.), M.L. Guedes et al. 7329 (ALCB, CEN*, CEPEC, HUEFS, HUESB, HUNEB, SPF, UESC); Laje, fazenda Sete Voltas, $12^{\circ} 39^{\prime}$ S, $39^{\circ} 05^{\prime} \mathrm{W}, 4$ maio 2016 (fl., fr.), T.T. Silva et al. 7 (HUEFS); Lagoa Real, povoado Tapera, na margem do rio São João, $14^{\circ} 14^{\prime}$ S, 42 ${ }^{\circ} 15^{\prime} \mathrm{W}, 545,5$ m s.n.m., 4 mar. 2019 (fl., fr.), N.X.M. Sousa et al. 582 (HURB); Livramento de Nossa Senhora, povoado Tabuleiro, às margens do rio do Paulo, $13^{\circ} 43^{\prime} \mathrm{S}, 41^{\circ} 58^{\prime} \mathrm{W}, 482 \mathrm{~m}$ s.n.m., 18 abr. 2019 (fl., fr.), N.X.M. Sousa et al. 620 (HURB); Macajuba, ca. 6 km E de Macajuba, na estrada para Baixa Grande, $12^{\circ} 5^{\prime}$ 'S, $40^{\circ} 18^{\prime} \mathrm{W}, 380$ m s.n.m., 26 jul. 2004 (fl., fr.), L.P. Queiroz et al. 9233 (HUEFS); Malhada, rodovia para o Distrito de Cana Brava, $3,5 \mathrm{~km}$ ao $\mathrm{S}$ da cidade, áreas alagadiças dos Baixadões do Rio São Francisco, $14^{\circ} 21^{\prime}$ 'S, $43^{\circ} 45^{\prime}$ W, 450 m s.n.m., 2 abr. 2001 (fl., fr.), J.G. Jardim, et al. 3417 (CEPEC, HUNEB, SPF, UESC); Mangue Seco, Litoral Norte, 19 out. 1996 (fl., fr.), Alunos da Ecologia Vegetal $1996.2 \mathrm{~s} / \mathrm{n}$ (HUNEB 35); Maragogipe, lado direito da pista, no sentido São Félix-Maragogipe, antes da entrada para Coqueiros, 14 fev. 2013 (fl., fr.), S.F. Conceição et al. 857 (HURB); Maraú, zona costeira, $5 \mathrm{~km}$ ao $\mathrm{N}$ para Maraú, ao longo da rodovia para Campinho, $14^{\circ} 04^{\prime} \mathrm{S}$, 3858'W, 0-50 m s.n.m., 17 maio 1980 (fl., fr.), R.M. Harley 22155 (CEPEC); Mata de São João, Sauípe, fazenda Sauípe, Construtora N. Odebrecht, 25 fev. 1986 (fl., fr.), H.P. Bautista et al. 1047b (CEPEC, HRB, HUEFS); Miguel Calmon, entre a fazenda Pé de Serra e o Riacho do Caldeirão, $11^{\circ} 24^{\prime}$ 'S, $40^{\circ} 33^{\prime}$ W, 820 m s.n.m., 5 abr. 2001 (fl., fr.), N.G. Jesus et al. 1282 (CEPEC, HRB, HUEFS, HUNEB, UESC); Milagres, BR-116, embaixo da ponte, $13^{\circ} 07^{\prime}$ 'S, 3858’W, 19 ago. 2015 (fl., fr.), L.Y.S. Aona et al. 4173 (HURB, MAC); Mirangaba, a $8 \mathrm{~km}$ de Mirangaba, $11^{\circ} 02^{\prime} \mathrm{S}, 40^{\circ} 37^{\prime} \mathrm{W}, 1$ set. 1981 (fl., fr.), J.C.D.A. Ferreira 67 (HRB); Morpará, baixada sujeita

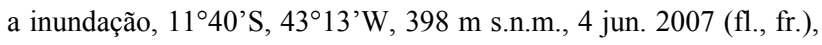
A.A. Conceição et al. 2308 (HUEFS); Morro de Chapéu, Cachoeira do Ventura, $11^{\circ} 40^{\prime} \mathrm{S}, 41^{\circ} 00^{\prime} \mathrm{W}, 844$ m s.n.m., 14 jul. 2018 (fl., fr.), N.X.M. Sousa et al. 504 (HURB); Mucugê, próximo ao posto de gasolina, na entrada da cidade, $13^{\circ} 00^{\prime} \mathrm{S}, 41^{\circ} 22^{\prime} \mathrm{W}, 1.016,5 \mathrm{~m}$ s.n.m., 2 jul. 2018, (fl., fr.), N.X.M. Sousa et al. 491 (HURB); Mucuri, 14$17 \mathrm{~km}$ a W de Mucuri, 13 set. 1978 (fl., fr.), S. A. Mori et al. 10438 (CEPEC); Mundo Novo, fazenda Jequitibá, $12^{\circ} 02^{\prime} \mathrm{S}, 40^{\circ} 29^{\prime} \mathrm{W}, 604$ m s.n.m., 29 jul. 2006 (fl., fr.), P.A. Melo 87 (HUEFS, HURB); Muniz Ferreira, fazenda Sete Brejos, córrego sobre a ponte, $13^{\circ} 01^{\prime} \mathrm{S}, 39^{\circ} 07^{\prime} \mathrm{W}, 5$ maio 2015 (fl., fr.), W.O. Fonseca 126 (HURB); Muritiba, borda da Lagoa da Pedreira, estrada de Muritiba, $1 \mathrm{~km}$ depois do portal da entrada, $12^{\circ} 36^{\prime}$ 'S, $39^{\circ} 00^{\prime} \mathrm{W}, 182 \mathrm{~m}$ s.n.m., 12 nov. 2014 (fl., fr.), L.Y.S. Aona 3604 (HURB); Mutuípe, Duas Barras do Fogo, 25 jan. 2019 (fl., fr.), T. Sousa 45 (HURB); Nazaré, lagoa, 27 ago. 2015 (fl., fr.), N.X.M. Sousa et al. 145 (HURB); Nova Ibiá, rodovia BA-120, fazenda Pedra do Sino, $13^{\circ} 42^{\prime}$ 'S, 39³3'W, 161,5 m s.n.m., 8 jun. 2018, (fl., fr.), N.X.M. Sousa 308 (HURB); Nova Soure, $11^{\circ} 14^{\prime}$ 'S, $38^{\circ} 29^{\prime} \mathrm{W}, 23$ set. 2004 (fl., fr.), A.M.M. Almeida s.n. (ALCB 67131, CEPEC 107439); Paulo Afonso, fazenda Arrasta Pé, 18 maio 1981 (fl., fr.), L.M.C. Gonçalves 70 (CEPEC); Remanso, estrada para Pilão Arcado, entrada à direita, ca. $29 \mathrm{~km}$ da cidade, $09^{\circ} 45^{\prime} \mathrm{S}$, $42^{\circ} 18^{\prime}$ W, 414 m s.n.m., 16 jun. 2001 (fl., fr.), T.S. Nunes et al. 469 (CEPEC, HUEFS, HUNEB, UESC); Ribeira do Pombal, 19 maio 1981 (fl., fr.), G.C.P. Pinto 134 (CEPEC); Rui Barbosa, Serra do Orobó, acima da zona das velózias, $12^{\circ} 18^{\prime} \mathrm{S}, 40^{\circ} 29^{\prime} \mathrm{W}, 640-807 \mathrm{~m}$ s.n.m., 18 dez. 2004 (fr.), L.P. Queiroz et al. 9888 (HUEFS); Salvador, área de Pituaçu (UCSAL), $12^{\circ} 57^{\prime} \mathrm{S}, 38^{\circ} 25^{\prime} \mathrm{W}, 18 \mathrm{fev}$. 1992 (fl., fr.), L. Paraguassu et al. 15 (ALCB, HRB); Santa Cruz da Vitória, fazenda Sou de Deus, Área Exp. do CEPEC, 19 ago. 1980 (fl., fr.), O.S. Filho et al. 23 (CEPEC); Santa Cruz Cabrália, 5 km de Santa Cruz Cabrália, 16²19'S, 3901'W, 18 mar. 1974 (fl., fr.), R.M. Harley 17147 (CEPEC); Santa Luz, fazenda Fontinha, tanque do governo, $11^{\circ} 17^{\prime}$ 'S, 394 'W, 4 set. 2009 (fl., fr.), C.T. Lima 222 (HUEFS); Santa Terezinha, Recôncavo Sul, margem do rio Paraguaçu, 12 ${ }^{\circ} 46^{\prime}$ 'S, 39³1'W, 7 maio 2016 (fl., fr.), M.L. Guedes et al. 24602 (ALCB); Santo Amaro, próximo ao lago, na beira da estrada, $12^{\circ} 38^{\prime} \mathrm{S}, 38^{\circ} 45^{\prime} \mathrm{W}, 22$ set. 2014 (fl., fr.), N.X.M. Sousa et al. 38 (CEPEC, HURB); Santo Antônio de Jesus, córrego em uma estrada vicinal, BR-101, lado esquerdo, sentido Teolândia, $13^{\circ} 00^{\prime}$ 'S, $39^{\circ} 15^{\prime}$ W, 29 jan. 2015 (fl., fr.), N.X.M. Sousa et al. 110 (HURB); Sento Sé, $18 \mathrm{~km}$ a NW Lagoinha, 5,5 km SW de Delfino, rodovia para Minas do Mimoso, $10^{\circ} 20^{\prime} \mathrm{S}, 41^{\circ} 20^{\prime} \mathrm{W}, 950 \mathrm{~m}$ s.n.m., 7 mar. 1974 (fl., fr.), R.M. Harley 16941 (CEPEC, NY*, US*); São Felipe, Umbuzeiro, área alagada, 12 dez. 2013 (fr.), G. Costa et al. 834 (HURB); São Félix, distrito Beija-Flor, 1240’S, 3857’W, $295 \mathrm{~m}$ s.n.m., 24 jul. 2012 (fl., fr.), L.Y.S. Aona et al. 1522 (HURB); São 
Francisco do Conde, São Bento, Rua do Cais, próximo ao lago, $12^{\circ} 36^{\prime}$ 'S, 3841'W, 22 set. 2014 (fl., fr.), N.X.M. Sousa et al. 34 (HURB); São Gonçalo dos Campos, chácara Sinhá, 2 km da entrada para São Gonçalo a partir da BR-101, 12²5’S, 3855’ W, 219 m s.n.m., 12 nov. 2014 (fl., fr.), L.Y.S. Aona 3626 (HURB); Sapeaçu, ca. 4-4,5 km, em direção a Castro Alves, Lagoa do Padre, à direita, 8 set. 2015 (fl., fr.), N.X.M. Sousa 31 (HURB); Saubara, lagoa, $12^{\circ} 45^{\prime}$ 'S, $38^{\circ} 46^{\prime} \mathrm{W}$, 35 m s.n.m., 15 jun. 2015 (fr.), G. Costa 1401 (HURB); Senhor do Bonfim, Distrito de Carrapichel, Serra do Santana, Fazenda da Banana, pasto próximo ao córrego, $10^{\circ} 21^{\prime} \mathrm{S}, 40^{\circ} 11^{\prime} \mathrm{W}, 698 \mathrm{~m}$ s.n.m., 18 out. 2011 (fl., fr.), C.O. Souza et al. 46 (HVASF); Serra Preta, 7 km W do Ponto de Serra Preta, fazenda Santa Clara, $12^{\circ} 10^{\prime} \mathrm{S}, 39^{\circ} 20^{\prime} \mathrm{W}, 17$ jul. 1985 (fl., fr.), L.R. Noblik et al. 4141 (ALCB, CEPEC, HUEFS, HUNEB); Sobradinho, Baixo Médio São Francisco, lagoa próximo à Sobradinho, $09^{\circ} 28^{\prime}$ 'S, $40^{\circ} 49^{\prime} \mathrm{W}, 385$ m s.n.m., 22 set. 2009 (fl., fr.), F.S. Gomes et al. 269a (ALCB, HUEFS); Tanhaçu, povoado Sussuarana, às margens do Rio de Contas, $14^{\circ} 09^{\prime} \mathrm{S}, 41^{\circ} 12^{\prime} \mathrm{W}, 332,5$ m s.n.m., 20 abr. 2019 (fl., fr.), N.X.M. Sousa et al. 642 (HURB); Tucano, povoado Bizamum, ca. 23 km de Tucano, 1053'S, 3858'W, 213 m s.n.m., 5 jun. 2004 (fl., fr.), D. Cardoso 76 (HUEFS); Una, Área do Ecoparque - IESB, entrada no Km 46 da BA-001, Ilhéus-Itabuna, área próxima à REBIO - Uma, $15^{\circ} 09^{\prime} \mathrm{S}, 39^{\circ} 05^{\prime} \mathrm{W}, 23$ out. 2004 (fl., fr.), A.M. Amorim et al. 4312 (CEPEC); Urandi, BA-263, sentido Licínio de AlmeidaUrandi, lado esquerdo, na cachoeira, a $9 \mathrm{~km}$ da cidade, $14^{\circ} 44^{\prime} \mathrm{S}$, 42³5'W, 846 m s.n.m., 11 nov. 2019 (fl., fr.), N.X.M. Sousa et al. 733 (HURB); Valença, Guaibim, Área de Proteção Permanente, 9 nov. 2018 (fl., fr.), G.V. Fonseca et al. 407 (HURB); Varzedo, córrego em área brejosa, 16 abr. 2015 (fl., fr.), N.X.M. Sousa et al. 113 (HURB); Wagner, Chapada Diamantina, margem do rio Utinga, $12^{\circ} 00^{\prime} \mathrm{S}$, 37²' W, 30 ago. 2018 (fl., fr.), M.L. Guedes et al. 30716 (ALCB); Wenceslau Guimarães, rodovia BA-120, povoado Indaiá, ao lado da Unidade de Saúde da Família, 13²45'S, 39³1'W, 109 m s.n.m., 8 jul. 2018 (fl., fr.), N.X.M. Sousa et al. 298 (HURB).

Ludwigia octovalvis se destaca das demais espécies da Bahia pelas sementes globosas, com rafe expandida, sem camada corticosa exposta. Apresenta folhas linearlanceoladas a lineares com face adaxial glabra e abaxial glabrescente ou glabra (Figura 4A) sobre solos arenosos e folhas oblongas, oval-lanceoladas ou lanceoladas com face adaxial glabrescente e abaxial pilosa a pubescente (Figura 4B) sobre solos argilosos e siltosos (Sousa et al. 2019).

Devido ao indumento piloso, pode ser confundida com L. leptocarpa, principalmente quando herborizada. Entretanto, L. octovalvis apresenta flores 4-meras (Figura 4A, B), às vezes 5-meras, e frutos cilíndricos a subcilíndricos (Figura 1Y), com sementes plurisseriadas, globosas, não envoltas pelo endocarpo (Figura 1Z), enquanto $L$. leptocarpa apresenta flores 5-meras, às vezes 6(-8)-meras (Figura 3E), diferindo principalmente pelos frutos subcilíndricos (Figura 1Q), com sementes unisseriadas, oblongo-achatadas, envoltas pelo endocarpo em forma de ferradura (Figura 1R, S).

Ludwigia sect. Myrtocarpus (Munz) H.Hara, J. Jap. Bot. 28: 291. 1953.

Caules cilíndricos ou subcilíndricos, eretos, com raízes laterais fibrosas e raros pneumatóforos brancos. Folhas alternas, com margens inteiras, ou levemente, ou irregularmente serrilhadas. Corola amarela; androceu diplostêmone. Cápsulas 4(5)-angulares a levemente 4(5)-angulares, cilíndrico-obcônicas, obcônicas ou obpiramidais, com paredes finas, irregularmente deiscentes. Sementes plurisseriadas não envolvidas pelo endocarpo; rafe com camada corticosa exposta. Números cromossômicos: 8, 16, 24, 32, 40, 48 e 64.

$\mathrm{Na}$ Bahia, apresenta seis espécies: L. brachyphylla, $L$. elegans, $L$. nervosa, $L$. rigida, $L$. sericea e $L$. tomentosa.

2.8. Ludwigia brachyphylla (Micheli) H.Hara, J. Jap. Bot. 28: 291. 1953.

Figuras 1C, D, 2A-C e 6; Munz (1947: fig. 19) e Ramamoorthy \& Zardini (1987: fig. 23).

Ervas a subarbustos, anuais a perenes, eretos, $0,8-$ $1,4 \mathrm{~m}$ alt.; caules ramificados, cilíndricos a subcilíndricos, hirsutos, ramos densamente hirsutos e esbranquiçados nas extremidades. Folhas com lâmina $0,9-4,2 \times 0,3-1,7 \mathrm{~cm}$, verde em ambas as faces, a adaxial glabrescente, a abaxial hirsuta a pubérula, oblonga a oval, cartácea a membranácea, ápice acuminado e mucronado, geralmente preto, base arredondada, obtusa, raramente cuneada, margens inteiras, séssil; estípula 1-3 mm compr. Flores 4-meras, 2,8-3,4 cm compr.; sépalas 7-12 × 3-5 mm, verdes a verde-avermelhadas em ambas as faces, a adaxial glabra, a abaxial hirsuta a pubérula, ovais a lanceoladas, ápice acuminado a agudo; pétalas 1-1,8 × 1-1,8 cm, orbicular-obovadas, ápice arredondado, levemente emarginado; estames desiguais, filetes e anteras eretos; nectário levemente convexo, ápice plano; estigma capitado. Cápsulas 1-1,6 cm $\times 2-5 \mathrm{~mm}$, verdes a verdeavermelhadas, levemente 4-angulares, obcônicas, hirsutas; pedicelo 0,7-2,2 cm compr.; bractéola 1-4 mm compr., na base dos frutos. Sementes ca. $6 \times 2 \mathrm{~mm}$, amarelo-acastanhadas, oblongoides; rafe proeminente, comprimento igual ao das sementes.

Endêmica do Brasil, ocorre no domínio fitogeográfico do Cerrado, em Brasilia, Distrito Federal, Goiás e Minas Gerais (Zeferino et al. 2020). E2/3 e F3: Chapadão Ocidental da Bahia, no Cerrado e na transição para Caatinga (Figura 6), em matas ciliares, ambientes úmidos e alagados, nas margens e bancos de areia dentro dos rios, em solos arenosos. Coletadas com flores e frutos de março a agosto.

Material selecionado - Barreiras, Palmeiral, $12^{\circ} 30^{\prime} \mathrm{S}, 45^{\circ} 5^{\prime} \mathrm{W}$, 594 m s.n.m., 16 jun. 2007 (fl., fr.), A. Cotrim et al. 504 (HUEFS); Correntina, Chapadão Ocidental da Bahia, margens e bancos de areia do rio Corrente, próximo a Correntina, brejo e região arborizada,

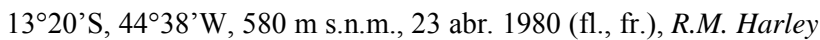
21691 (CEPEC, K*, NY*, SP, SPF, UEC, US*) e 21691a (CEPEC); São Desidério, Manoel de Souza, área antropizada, $12^{\circ} 31^{\prime} \mathrm{S}$, $45^{\circ} 05^{\prime}$ W, 590 m s.n.m., 21 jul. 2007 (fl., fr.), A. Cotrim et al. 1122 (HUEFS).

Ludwigia brachyphylla apresenta, na fase reprodutiva, folhas basais (ca. $4 \times 1,7 \mathrm{~cm}$ compr.) mais próximas $(1,3-2 \mathrm{~cm})$ umas das outras e, à medida que se aproximam do ápice, ficam menores (ca. $9 \times 3 \mathrm{~mm}$ ) e 
mais distantes entre si $(2,6-3 \mathrm{~cm}$ compr.). Durante o cultivo dessa espécie, foram observadas raízes nodais fibrosas e, após o surgimento de novos ramos, pneumatóforos brancos, caules e folhas hirsutos e ramos densamente hirsutos nas extremidades, principalmente nos botões florais e nas folhas mais jovens, com ápice acuminado e mucronado na extremidade, de coloração preta. Durante o período reprodutivo, foi possível verificar os caracteres morfológicos relevantes, como a forma obcônica do fruto, apresentando-se levemente 4angular (Figura 1C), e da semente oblongoide com rafe proeminente (Figura 1D), além da coloração amarela da corola na antese (Figura 2A) e amarelo-clara na senescência (Figura 2B).

Ramamoorthy \& Zardini (1987) indicaram a ocorrência de L. albiflora na Bahia a partir dos espécimes Harley 21691 (CEPEC 27922) e 21691a (CEPEC 27924). Entretanto, ao examinar o exemplar Jardim 887 (CEPEC, NY*) e material em cultivo de indivíduos coletados na localidade de Correntina e seu entorno, foi reconhecida somente $L$. brachyphylla, que apresenta corola amarela (Figura 2A, B), e não $L$. albiflora, com corola branca e mácula amarela, eventualmente cor creme.

\subsection{Ludwigia elegans (Cambess.) H.Hara, J. Jap. Bot.} 28: 292.1953.

Figuras 1G, H, 2E, F e 7; Munz (1947: fig. 20), Ramamoorthy \& Zardini (1987: fig. 20) e Zardini \& Raven (1997: fig. 5).

Ervas a subarbustos, anuais a perenes, eretos, 1,31,4 m alt.; caules ramificados, subcilíndricos, glabrescentes a glabros, ramos densamente pubescentes e esbranquiçados nas extremidades. Folhas com lâmina 4-19 × 1,7-4,5 cm, ambas as faces verdes, às vezes, verde-acinzentadas, a adaxial glabrescente a glabra, a abaxial pubescente a glabrescente, principalmente na nervura central e nas nervuras secundárias, lanceolada, largo-elíptica, cartácea a membranácea, acuminada em ambas as extremidades, margens levemente serrilhadas pelos hidatódios epitemais; pecíolo 3-15 $\mathrm{mm}$ compr.; estípula inconspícua. Flores 4-meras, 3,6-4,2 cm; sépalas 14-16 × 4-5 mm, face adaxial verde, a abaxial verde a verde-avermelhadas, glabrescentes a glabras, lanceolar-deltoides, ápice agudo a acuminado; pétalas 1,8-2 × 2-2,2 mm, obovais a orbiculares, ápice arredondado, emarginado; estames subiguais, filetes curtos, curvados, anteras curvadas, próximas das pétalas; nectário piramidal, 4-angular, ápice plano; estigma capitado. Cápsulas 1,4-1,9 cm × 5-7 mm, verdes, 4-angulares, obcônicas, pubescentes a glabras, principalmente nos ângulos; pedicelo 2,5-4,5 cm compr.; bractéola 9-11 mm compr., na base dos frutos. Sementes ca. $4 \times 2 \mathrm{~mm}$, amarelo-acastanhadas, oblongo-ovoides; rafe proeminente, comprimento igual ao das sementes.

Ocorre no Cerrado, Mata Atlântica, Pampa, Pantanal, em sete estados das Regiões Centro-Oeste, Sudeste e Sul (Zeferino et al. 2020), sendo este o primeiro registro para a Bahia. F8 e G8/9: Mata Atlântica e Cerrado, no Chapadão Ocidental da Bahia (Figura 7), em florestas ciliares, florestas estacionais semideciduais e florestas ombrófilas, em ambientes úmidos e alagados, margens e leito de rios e bancos de areia dentro dos rios, em solos arenosos. Coletada com flores e frutos de março a abril.

Material selecionado - Correntina, Chapadão Ocidental da Bahia, Balneário das Sete Ilhas, a 1,5 km do centro da cidade, Rio das Éguas, $13^{\circ} 20^{\prime}$ 'S, $44^{\circ} 37^{\prime} \mathrm{W}, 532$ m s.n.m., 6 mar. 2019 (fl., fr.), N.X.M. Sousa et al. 597 (ALCB, HURB); Ilhéus, 28 abr. 2019 (fl., fr.), L.Y.S Aona 4970 (HURB); Santa Maria da Vitória, próximo da BR-349, Barra de São José, nas margens do rio Guará, $13^{\circ} 23^{\prime}$ 'S, $44^{\circ} 20^{\prime} \mathrm{W}, 467$ m s.n.m., 5 mar. 2019 (fl., fr.), N.X.M. Sousa et al. 596 (ALCB, HURB).

Nos herbários, Ludwigia elegans é confundida com L. tomentosa. Entretanto, L. elegans apresenta folhas com 19-34 nervuras secundárias, regularmente paralelas, assim como as nervuras terciárias (Figura 2E), já L. tomentosa possui 12-26 nervuras secundárias, proeminentes, saindo de forma irregular da nervura central, raramente paralelas, e as nervuras terciárias são anastomosadas, raramente paralelas. Em L. elegans, as folhas possuem hidatódios epitemais nas margens, tornando-as levemente serrilhadas, enquanto $L$. tomentosa apresenta hidatódios disformes com glândulas avermelhadas, tornando-as irregularmente serrilhadas (Figura 4G) (Castells et al. 1979). A flor de L. elegans apresenta filetes curtos e curvados e anteras curvadas próximas às pétalas (Figura $2 \mathrm{~F}$ ), em vez de filetes levemente curvados e anteras eretas a levemente curvadas quase se aproximando das pétalas (Figra 4F), como em L. tomentosa. O fruto de L. elegans é 4-angular obcônico e as semente oblongo-ovoides com rafe proeminente (Figura $1 \mathrm{G}, \mathrm{H}$ ), enquanto em L. tomentosa, o fruto é 4-angular obpiramidal, pubescente, e as sementes largo-elipsoides com rafe bem proeminente (Figura 1KK, LL).

2.10. Ludwigia nervosa (Poir.) H.Hara, J. Jap. Bot. 28: 293. 1953

Figuras 1V-X, 3H e 11; Munz (1947: fig. 10), Ramamoorthy \& Zardini (1987: fig. 32), Zardini \& Raven (1997: fig. 13) e Lovo \& Zappi (2018: fig. 3C, D). Nome popular: cruz-de-malta.

Arbustos a subarbustos, anuais a perenes, eretos, 0,9-3 m alt.; caules muito ramificados, cilíndricos a subcilíndricos, glabrescentes a glabros, ramos densamente pubescentes a pubérulos e esbranquiçados nas extremidades. Folhas com lâmina 1,8-8 × 0,4-1,5 $\mathrm{cm}$, ambas as faces verdes, a adaxial glabra, pubérula na nervura central e nas secundárias, a abaxial pubescente a pubérula, oval, elíptica, lanceolada a oblonga, coriácea, ápice agudo, raro obtuso, base arredondada, obtusa a levemente atenuada, margem inteira ou levemente serrilhada pelos hidatódios epitemais; pecíolo 1-3 mm compr. (ou folhas sésseis); estípula 2$6 \mathrm{~mm}$ de compr. Flores 4-meras, 3,6-4 cm compr.; sépalas 7-14 × 2,5-4 mm, ambas as faces verdes, a 
adaxial glabrescente, a abaxial pubérula a glabrescente, lanceoladas, ápice agudo a acuminado; pétalas 1,2-1,5 $\times 1,2-1,5 \mathrm{~cm}$, amarelas, orbiculares, ápice arredondado, levemente emarginado; estames desiguais, filetes e anteras eretos; nectário convexo, ápice plano; estigma globoso. Cápsulas $0,8-1,5 \times 0,4-1 \mathrm{~cm}$, verdes, cilíndrico-obcônicas, pubescentes a glabras; pedicelo $1-$ 2,9 cm compr.; bractéola 2-2,9 mm compr., na base dos frutos. Sementes ca. $6 \times 1 \mathrm{~mm}$, amarelo-acastanhadas, oblongoides; rafe proeminente, com extremidade basal pontiaguda, em forma de cone, comprimento igual ao das sementes.

Ocorre na Amazônia, Caatinga, Cerrado, Mata Atlântica, Pantanal, em 14 estados, incluindo a Bahia, e em todas as Regiões do Brasil (Zeferino et al. 2020). D2/3, D9, E2, E6, F6, G3, I8, J8 e K8: Chapada Diamantina, no Chapadão Ocidental da Bahia, na bacia do São Francisco e na Mata Atlântica (Figura 11), em mata caducifólia, na restinga, em formações savânicas e campestres, em matas ciliares, nas margens e leito de rios, riachos e cachoeiras, em solos arenosos, siltosos e entre as rochas. Coletada com flores e frutos entre abril e janeiro.

Material selecionado - Abaíra, Distrito de Catolés, Guarda-

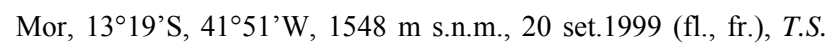
Nunes et al. 95 (CEPEC, HUEFS); Alcobaça, Km 11 da BR-101, Teixeira de Freitas/Rancho, 17 ago. 1972 (fl., fr.), T.S. Santos 2401 (CEPEC); Barreiras, Palmeiral, 12³0'S, 455'W, 594 m s.n.m., 16 jun. 2007 (fl., fr.), A. Cotrim et al. 505 (HUEFS); Belmonte, Barrolândia, Estação Experimental "Gregorio Bondar" CEPLAC, 48 km da BR-101 de Belmonte, 1608'S, 39¹5'W, 13 maio 1993 (fl., fr.), W.W. Thomas et al. 9907 (CEPEC, NY*); Caravelas, Córrego da Onça, 19 jun. 1985 (fl., fr.), G. Hatschbach et al. 49502 (HCF*, HUFU*); Cocos, ca. $24 \mathrm{~km} \mathrm{~W}$ de Cocos, Tamanduá, 14¹7's, 444' 'W, 545 m s.n.m., 16 maio 2001 (fl., fr.), F. França et al. 3609 (CEPEC, HUEFS); Formosa do Rio Preto, Primavera, $11^{\circ} 02^{\prime} \mathrm{S}$, 4504'W, 465 m s.n.m., 3 nov. 2007 (fl., fr.), G. Araújo et al. 385 (HUEFS); Itapicuru, 1 abr. 1976, (fl., fr.), T.P. Ramamoorthy et al. 328 (US*); Mucugê, Estiva Nova, na estrada Mucugê-Guiné, $12^{\circ} 52^{\prime}$ 'S, 41 ${ }^{\circ} 30^{\prime} \mathrm{W}, 1054$ m s.n.m., 16 jul. 1996, H.P. Bautista et al. 3695 (ALCB); Mucuri, 4 km a W de Mucuri, 13 set. 1978 (fl., fr.), S.A. Mori et al. 10462 (CEPEC, NY*, RB*); Palmeiras, próximo ao Morro do Pai Inácio, 12²7’S, 41²8’W, 946 m s.n.m., 31 out. 2014 (fl., fr.), T. Vieira 124 (HUEFS); Piatã, estrada para Lençóis, 1329'S, 41³4'W, 1199 m s.n.m., 29 out. 2014 (fl., fr.), T. Vieira 93 (HUEFS); Rio de Contas, na cachoeira da fazenda Vacaro, $13^{\circ} 06^{\prime} \mathrm{S}$, 41 ${ }^{\circ} 46^{\prime}$ W, 1237,5 m s.n.m., 8 jan. 2019 (fl., fr.), N.X.M. Sousa et al. 543 (HURB); São Desidério, fazenda Sikuê, 1257'S, 45³3'W, 23 ago. 2008 (fl., fr.), E.P. Queiroz 3078 (HRB).

Ludwigia nervosa é confundida com L. rigida quando herborizada, mas apresenta sépalas verdes, pubérulas a glabrescentes em ambas as faces, enquanto em L. rigida, elas são frequentemente verdes a verdeavermelhadas e glabras adaxialmente, e verdes ou verde-avermelhadas a verde-vináceas (Figura 1EE) e glabrescentes a glabras nas nervuras centrais. Além disso, suas folhas ficam distribuídas ao longo do caule, geralmente 1,6-2,5 mm distantes entre si, enquanto em L. rigida, as folhas são geralmente espaçadas, $5-59 \mathrm{~mm}$ distantes entre si. Os caracteres morfológicos mais relevantes de L. nervosa são o nectário convexo com 2$5 \mathrm{~mm}$ compr. (Figura 1W), os estiletes com 1-1,2 mm compr., o estigma 1-2,3 mm compr., globoso, os frutos cilíndrico-obcônicos verdes (Figura $1 \mathrm{~V} ; 3 \mathrm{H}$ ) e a rafe com extremidade basal pontiaguda, em forma de cone (Figura 1X). Já L. rigida apresenta nectário piramidal, 4-angular, com 1-3 mm compr. (Figura 1FF), estilete com 2-3,6 mm compr., estigma $1-2,4 \mathrm{~mm}$ compr., capitado, frutos 4-angulares, obcônicos, verdes, regularmente avermelhados a verde-vináceos (Figura 1EE), e a rafe apresenta extremidade basal curvada sobre o tegumento (Figura 1GG).

\subsection{Ludwigia rigida (Miq.) Sandwith, Kew Bull.} 19(2): 197. 1965.

Figuras 1EE-GG, 4D e 14; Ramamoorthy \& Zardini (1987: fig. 34), Zardini \& Raven (1997: fig. 16) e Cumana Campos (2010: fig. 11).

Nome popular: corticeiro.

Arbustos a subarbustos, anuais a perenes, eretos, 1$4 \mathrm{~m}$ alt.; caules muito ramificados, cilíndricos a subcilíndricos, glabrescentes a glabros, ramos esparsamente pubescentes a pubérulos e esbranquiçados nas extremidades. Folhas com lâmina 1,8-8,8 × 0,3-2 $\mathrm{cm}$, ambas as faces verdes, geralmente avermelhada nas margens, glabra, elíptica, estreito-elíptica, lanceolada, coriácea, ápice acuminado a agudo, base aguda, arredondada, margens inteiras ou levemente serrilhadas pelos hidatódios epitemais; pecíolo 1,4-3,9 mm compr. (ou folhas sésseis); estípula 2-6 mm compr. Flores 4(5)meras, $2,2-2,8 \mathrm{~cm}$, sépalas $7-15 \times 2-6,2 \mathrm{~mm}$, face adaxial verde a verde-avermelhada, glabra, a abaxial verde, verde-avermelhada a verde-vinácea, glabra e glabrescente na nervura central, lanceoladas a largolanceoladas, ápice acuminado a agudo; pétalas 1,1-1,8 $\times 1,1-1,8 \mathrm{~cm}$, amarelas, orbiculares, ápice arredondado; estames subiguais, filetes curvados, anteras levemente curvadas, quase aproximando-se das pétalas; nectário piramidal, 4(5)-angular, ápice plano, estigma capitado. Cápsulas $0,8-1,9 \times 0,3-0,5 \mathrm{~cm}$, verdes, verdeavermelhadas a verde-vináceas, 4(5)-angulares, obcônicas, pubérulas a glabra; pedicelo 7-35 mm compr.; bractéola inconspícua a 1,3-2,4 mm compr., na base dos frutos. Sementes ca. $6 \times 2 \mathrm{~mm}$, amareloacastanhadas, oblongoides; rafe proeminente, com extremidade basal curvada sobre o tegumento, comprimento igual ao das sementes.

Ocorre em 10 estados brasileiros, incluindo a Bahia, nas Regiões Centro-oeste, Norte e Nordeste, nos domínios da Amazônia, Caatinga e Cerrado (Zeferino et al. 2020). C5, C6, D5, D6, E2, E6, F3, F5 e F6: Chapada Diamantina, no Chapadão Ocidental da Bahia, na bacia do São Francisco (Figura 14), contatos entre cerrados (s.1.) e caatingas (s. str.), em mata semicaducifólia, florestas e formações savânicas e campestres, sendo encontrada em matas ciliares, em ambientes úmidos a alagados, nas margens e leito de rios, riachos e cachoeiras, em solos arenosos, siltosos e 
entre as rochas. Coletada com flores e frutos de abril a outubro.

Material selecionado - Andaraí, estrada BA-142, margens do rio Paraguaçu, 1282'S, 41³2'W, 327,5 m s.n.m., 13 ago. 2016, (fl., fr.), N.X.M. Sousa et al. 157 (EVB*, HURB); Boninal, Cachoeira da Cotia, povoado Ministro, entre as rochas da cachoeira, $12^{\circ} 48^{\prime} \mathrm{S}$, 41ํㄱ'W, 885,5 m s.n.m., 19 jun. 2018, (fl., fr.), N.X.M. Sousa et al. 386 (ALCB, HURB); Correntina, $37 \mathrm{~km}$ ao $\mathrm{N}$ de Correntina, rodovia para Inhaúmas, Chapadão Ocidental da Bahia, $13^{\circ} 07^{\prime} \mathrm{S}, 44^{\circ} 47^{\prime} \mathrm{W}$, 580 m s.n.m., 29 abr. 1980, (fl., fr.), R.M. Harley 21947 (CEPEC, SPF, UEC, UESC); Érico Cardoso, Vereda, estrada Morro do Fogo Vereda, 1316'S, 426'W, 1027 m s.n.m., 4 jul. 2001 (fl., fr.), H.P. Bautista et al. 3300 (ALCB, CEPEC, HUEFS); Lençóis, margem do rio Mucugezinho, $12^{\circ} 27^{\prime}$ S, $41^{\circ} 21^{\prime}$ 'W, 729 m s.n.m., 21 out. 2003 (fl., fr.), A.S. Conceição et al. 753 (HUEFS); Luís Eduardo Magalhães, Oeste, $12^{\circ} 18^{\prime}$ S, $45^{\circ} 43^{\prime}$ W, 710 m s.n.m., 21 set. 2003, (fl., fr.), B.A. Anjos 29 (ALCB); Morro do Chapéu, rodovia BA-052, a 20 km em direção a Feira de Santana, ponte do rio Ferro Doido, 31 ago. 1990, (fl., fr.), J.L. Hage et al. 2343 (CEPEC, SPF, UESC); Mucugê, próximo ao posto de gasolina, na entrada da cidade, $13^{\circ} 00^{\prime} \mathrm{S}$, $41^{\circ} 22^{\prime}$ W, 1016,5 m s.n.m., 2 jul. 2018 (fl., fr.), N.X.M. Sousa et al. 494 (ALCB, HURB); Palmeiras, BR-242, nas margens do Rio Preto, ao lado da ponte, $12^{\circ} 27^{\prime}$ 'S, $41^{\circ} 35^{\prime} \mathrm{W}, 713$ m s.n.m., 15 out. 2018, (fl., fr.), N.X.M. Sousa et al. 538 (HURB); Rio de Contas, estrada Livramento-Rio de Contas, BA-148, próximo à Bica da Cíntia, $13^{\circ} 62^{\prime}$ S, 41 $81^{\prime}$ 'W, 531 m s.n.m., 20 ago. 2016, (fl., fr.), N.X.M. Sousa et al. 196 (CEPEC, EVB*, HURB); Santo Inácio, saída para Poços, 116'S, 4243'W, 560 m s.n.m., 26 set. 1999 (fl., fr.), K.R.B. Leite et al. 13 (HUEFS, UEC); Sento Sé, área proposta do Parque Nacional Boqueirão da Onça, Nascente do Alegre, 10¹9'S, 41²7'W, 1079 m s.n.m., 4 set. 2013 (fl., fr.), D.S. Fernandes et al. 67 (HURB, HVASF); São Desidério, sitio Rio Grande, barragem Rio das Fêmeas, 5 out. 2007, (fl., fr.), M. Oliveira 3050 (UESC); Umburanas, estrada de Umburanas para Delfino, ca. $31,3 \mathrm{~km}$, ramal à esquerda, acesso à Serra da Empreitada, construção abandonada no

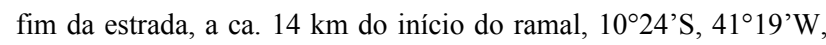
975 m s.n.m., 16 jul. 2004 (fl., fr.), P. Fiaschi et al. 2465 (CEPEC, $\left.\mathrm{NY}^{*}, \mathrm{SPF}\right)$; Xique-Xique, estrada para Barra, a ca. $21 \mathrm{~km}$ de XiqueXique, $11^{\circ} 01^{\prime}$ 'S, $42^{\circ} 43^{\prime}$ W, 415 m s.n.m., 3 jun. 1999, (fl., fr.), E. Melo et al. 2740 (HUEFS).

Apesar de pertencerem à mesma seção (Munz 1947; Ramamoorthy \& Zardini 1987), Ludwigia rigida e L. nervosa não apareceram proximamente relacionadas em estudos com dados moleculares (Liu et al. 2017). Entretanto, o efeito da poliploidia não encontra-se refletido adequadamente nessa classificação e parece necessária uma amostragem mais ampla da seção Myrtocarpus para que se possa esclarecer as relações entre essas espécies.

2.12. Ludwigia sericea (Cambess.) H.Hara, J. Jap. Bot. 28: 294. 1953.

Figuras 1II, JJ, 4E e 15.

Arbustos a subarbustos, anuais a perenes, eretos, 1$3 \mathrm{~m}$ alt.; caules ramificados, subcilíndricos, seríceos, ramos densamente seríceos a seríceos-tomentosos e alvo-acinzentados nas extremidades. Folhas com lâmina 1,7-4 × 0,7-1,4 cm, ambas as faces verdes, a adaxial pilosa, a abaxial serícea a seríceo-tomentosa, oval-lanceolada, cartácea, ápice acuminado a agudo, base arredondada a obtusa, margens inteiras; pecíolo $2-$ $3 \mathrm{~mm}$ compr. (ou folhas sésseis); estípula 5-8 mm compr. Flores 4-meras, 2,6-2,8 cm compr.; sépalas 8$12 \times 2,5-3 \mathrm{~mm}$, verdes, face adaxial glabra, a abaxial serícea, lanceoladas, ápice acuminado a agudo; pétalas $1,1-1,3 \times 1,1-1,3 \mathrm{~cm}$, amarelas, orbiculares, ápice emarginado; estames subiguais, filetes curtos, curvados, anteras levemente curvadas, quase aproximando-se das pétalas; nectário piramidal, 4-angular, ápice plano; estigma capitado. Cápsulas 6-9 × 3-4 mm, verdes, 4angulares, obcônicas ou obpiramidais, pilosas; pedicelo 0,9-1,5 cm compr.; bractéola inconspícua a ca. $7 \mathrm{~mm}$ compr., na base dos frutos. Sementes ca. $5 \times 2 \mathrm{~mm}$, amarelo-acastanhadas, oblongoides; rafe proeminente, comprimento igual ao das sementes.

No Brasil, ocorre nos domínios fitogeográficos do Cerrado, Mata Atlântica, Pampa, Pantanal, no Mato Grosso do Sul, Minas Gerais, Paraná, Rio de Janeiro, Rio Grande do Sul, Santa Catarina e São Paulo (Zeferino et al. 2020), sendo este o primeiro registro para a Bahia. G5: sul da porção baiana da Cadeia do Espinhaço, na Serra Geral, bacia do Rio de Contas, (Figura 15), contatos entre cerrados (s.l.) e caatingas (s.str.), em ambientes úmidos a alagados, nos campos rupestres, matas ciliares de riachos e cachoeiras, em solos arenosos e entre rochas. Coletada com flores e frutos em março, julho e dezembro.

Material selecionado - Licínio de Almeida, fazenda São Domingos de Baixo, riacho pedregoso, 4 mar. 2019 (fl., fr.), N.X.M. Sousa et al. 592 (HURB); ib., Serra Geral, Cachoeira das Sete Quedas, Serra do Salto, 14³7'S, 42³0'W, 724 m s.n.m., 14 jul. 2011 (fl., fr.), N. Roque et al. 3167 (ALCB).

Ludwigia sericea pode ser reconhecida pelo indumento densamente seríceos a seríceo-tomentosos nas extremidades dos ramos alvo-acinzentados, o arranjo dos estames subiguais, filetes curtos e curvados, anteras levemente curvadas, quase aproximando-se das pétalas, $o$ fruto 4-angulares, obcônico ou obpiramidais e sementes oblongoides, com rafe proeminente (Figura 1II, JJ).

\subsection{Ludwigia tomentosa (Cambess.) H.Hara, J. Jap.} Bot. 28: 294. 1953.

Figuras 1KK, LL, 4F, G e 15; Munz (1947: fig. 12), Ramamoorthy \& Zardini (1987: fig. 9) e Zardini \& Raven (1997: fig. 18).

Nome popular: corticeiro-gigante.

Arbustos a subarbustos, anuais a perenes, eretos, 0,6-3 m alt.; caules muito ramificados, lenhosos, subcilíndricos, tomentosos, acastanhados, ramos densamente tomentosos e acastanhados a alvoacinzentados nas extremidades. Folhas com lâmina 2$17 \times 0,9-5,1 \mathrm{~cm}$, face adaxial verde a verdeavermelhada, esparsamente híspida, às vezes, glabra e acinzentada na maturidade, a abaxial acastanhada ou alvo-acinzentada, tomentosa, às vezes pubescente, elíptica, lanceolada, oblonga, oboval, coriácea, ápice agudo a arredondado, base arredondada a obtusa, margens irregularmente serrilhadas pelos hidatódios 
glandulares disformes e avermelhados; pecíolo 1-8 mm compr. (ou folhas sésseis); estípula 1-2 mm compr. Flores 4(5)-meras, 5,1-5,8 cm compr.; sépalas 8-18 × 3-9 mm, face adaxial verde, pubescente a glabrescente, a abaxial verde a verde-avermelhada, tomentosa, lanceoladas, ápice agudo, atenuado; pétalas 1,5-2,8 $\times$ 1,2-2,8 $\mathrm{mm}$, amarelas, as obovais com ápice agudo, as orbiculares com ápice arredondado e emarginado; estames subiguais, filetes eretos a levemente curvados, anteras eretas a levemente curvadas, quase aproximando-se das pétalas; nectário piramidal, 4(5)angular, ápice plano; estigma capitado. Cápsulas 0,5$1,9 \mathrm{~cm} \times 4-9 \mathrm{~cm}$, verdes a verde-avermelhadas, 4(5)angulares, obpiramidais, pubescentes; pedicelo 1,3-4,3 cm compr.; bractéola $0,2-1,1 \mathrm{~cm}$ compr., na base dos frutos ou a $2 / 3$ da parte superior dos pedicelos. Sementes ca. $9 \times 5 \mathrm{~mm}$, amarelo-acastanhadas, largoelipsoides; rafe bem proeminente, comprimento igual ao das sementes.

No Brasil, ocorre nos domínios fitogeográficos da Caatinga e Cerrado, no Distrito Federal, Goiás, Mato Grosso, Mato Grosso do Sul, Minas Gerais, São Paulo, Tocantins, além da Bahia (Zeferino et al. 2020). D2, E3, E6, F3, F5, F6, G3, G5 e G8: Chapadão Ocidental Baiano, no sul da Chapada Diamantina e na região sul do estado (Figura 15). Ocorre em caatingas (s.str.) e cerrados (s.1.), em matas ciliares de florestas estacionais semideciduais e deciduais, em formações florestais, savânicas e campestres, em ambientes úmidos a alagados, nas margens e leito de rios, riachos e cachoeiras, em solos arenosos, siltosos e entre as rochas. Coletada com flores e frutos em todos os meses do ano.

Material selecionado - Abaíra, Distrito de Catolés, Água Limpa, próximp ao córrego, área degradada, campo rupestre, $13^{\circ} 17^{\prime}$ 'S, $41^{\circ} 52^{\prime}$ W, 1180 m s.n.m., 19 set. 1999 (fl., fr.), T.S. Nunes et al. 73 (HUEFS, UEC); Barreiras, estrada p/o aeroporto, entre 5 a $15 \mathrm{~km}$ a partir da sede, estrada para o aeroporto de Barreiras, Cerrado, 11 jun. 1992 (fl., fr.), A.M. Carvalho et al. 4072 (CEPEC); Boninal, povoado Capão do Jacu, às margens do rio Palmares, 28 dez. 2014 (fl., fr.), N.X.M. Sousa 73 (HUEFS, HURB, UEC); Cocos, ca. $24 \mathrm{~km}$ a W de Cocos, Tamanduá, $14^{\circ} 17^{\prime} \mathrm{S}, 44^{\circ} 43^{\prime} \mathrm{W}$, 545 m s.n.m., 16 maio 2001 (fl., fr.), F. França et al. 3611 (HUEFS, CEPEC); Correntina, margem a esquerda, sentido da foz, centro da cidade, Rio das Éguas, $13^{\circ} 20^{\prime}$ 'S, $44^{\circ} 38^{\prime}$ W, 526 m s.n.m., 7 mar. 2019 (fr., f1.), N.X.M. Sousa et al. 610 (HURB); Encruzilhada, fazenda Nossa Senhora Aparecida, 15³8'S, 405' $\mathrm{W}, 830 \mathrm{~m}$ s.n.m., 20 out. 2013 (fl.,fr.), E.L. Siqueira et al. 928 (HCF*); Érico Cardoso, Capão, estrada Porteira, em direção à Vereda, $13^{\circ} 16^{\prime} \mathrm{S}$, 4208'W, 1099 m s.n.m., 5 jul. 2001 (fl., fr.), H.P. Bautista et al. 3315 (CEPEC, HUEFS, HUNEB, UESC); Formosa do Rio Preto, $11^{\circ} 3^{\prime} \mathrm{S}, 45^{\circ} 16^{\prime} \mathrm{W}, 2$ abr. 2000 (fl., fr.), T.R.S. Silva et al. 43 (CEPEC, HUEFS); Itacaré/Ubaitaba, 17 abr. 1970 (fl., fr.), T.S. Santos 736 (CEPEC); Jaborandi, rodovia para Correntina, ca. 15 $\mathrm{km}$ da sede do município, solo arenoso, $13^{\circ} 32^{\prime} \mathrm{S}, 44^{\circ} 32^{\prime} \mathrm{W}, 660 \mathrm{~m}$ s.n.m., 19 abr. 2001 (fl., fr.), J.G. Jardim et al. 3713 (CEPEC, UESC); Licínio de Almeida, fazenda São Domingos de Baixo, riacho pedregoso, 4 mar. 2019 (fr.), N.X.M. Sousa et al. 591 (HURB); Livramento de Nossa Senhora, barragem de captação de água do DNOCS, ca. $500 \mathrm{~m}$ da rodovia Livramento-Rio de Contas,
6 nov. 2019 (fl., fr.), N.X.M. Sousa et al. 732 (HURB); Mucugê, estrada Boninal-Mucugê, povoado Capão Comprido, nas margens do rio, $12^{\circ} 59^{\prime}$ 'S, $41^{\circ} 38^{\prime}$ 'W, 1155,5 m s.n.m., 2 jul. 2018 (fl., fr.), N.X.M. Sousa et al. 465 (HURB); Piatã, caminho para a Cachoeira do Jovino, $13^{\circ} 03$ 'S, $41^{\circ} 50$ 'W, 1251 m s.n.m., 13 jun. 2014 (fl., fr.), M.L. Guedes et al. 21735 (ALCB, HURB); Rio de Contas, estrada Livramento-Rio de Contas, BA-148, próximo à Bica da Cíntia, $13^{\circ} 62^{\prime}$ 'S, $41^{\circ} 81^{\prime}$ W, 531 m s.n.m., 20 ago. 2016 (fl., fr.), N.X.M. Sousa 194 (HCF*, HURB); Ubaitaba, $21 \mathrm{~km}$ a E da BR-101, rodovia Ubaitaba-Itacaré, 9 fev. 1985 (fl., fr.), E. Zardini et al. 2227 (CEPEC); Urandi, BA-263, sentido Licínio de Almeida-Urandi, cachoeira a $9 \mathrm{~km}$ da cidade, $14^{\circ} 44^{\prime} \mathrm{S}, 42^{\circ} 35^{\prime} \mathrm{W}, 846 \mathrm{~m}$ s.n.m., 11 nov. 2019 (f1., fr.), N.X.M. Sousa et al. 734 (HURB).

As diferenças morfológicas em relação à espécie mais próxima de Ludwigia tomentosa são apresentadas em L. elegans.

Ludwigia sect. Pterocaulon Ramamoorthy, Ann. Missouri Bot. Gard. 66: 894. 1980.

Caules 4-angulares ou levemente 4-angulares, ou subcilíndricos, 4-alados ou estreitamente 4-alados, eretos, com raízes laterais fibrosas e raros pneumatóforos brancos. Folhas alternas, com base decorrente ou levemente decorrente apenas nas extremidades dos ramos, margens inteiras. Corola amarela; androceu diplostêmone. Cápsulas 4-angulares, oblongoides, 4-aladas ou não, com paredes finas, irregularmente deiscentes. Sementes plurisseriadas em cada lóculo, com ou sem extremidade basal curvada, não envolvidas pelo endocarpo; rafe com camada corticosa exposta. Número cromossômico: $\mathrm{n}=8$.

No estado da Bahia, está representada por $L$. decurrens, L. erecta e L. longifolia.

2.14. Ludwigia decurrens Walter, Fl. Carol.: 89. 1788. Figuras 1E, F, 2D e 6; Munz (1947: fig. 5), Ramamoorthy \& Zardini (1987: fig. 41), Zardini \& Raven (1997: fig. 3) e Lovo \& Zappi (2018: fig. 2A).

Ervas, anuais, eretas, ca. 1,2 $\mathrm{m}$ alt.; caules ramificados, 4-angulares, 4-alados, em decorrência da base das folhas, glabros, ramos glabrescentes nas extremidades. Folhas com lâmina 3-12 × 0,8-3,5 cm, ambas as faces verdes, a adaxial glabra, a abaxial glabrescente, lanceolada, linear-lanceolada, membranácea, ápice acuminado a agudo, base arredondada, decorrente, séssil; estípula ca. $2 \mathrm{~mm}$ compr. Flores 4-meras, 3,2-3,4 cm compr.; sépalas 1$1,1 \mathrm{~cm} \times 2,5-3 \mathrm{~mm}$, verdes em ambas as faces, a adaxial glabra, a abaxial glabrescente, lanceoladas, ápice acuminado; pétalas $1,5-1,6 \mathrm{~cm} \times$ ca. $4 \mathrm{~mm}$, obovais, ápice arredondado; estames desiguais, filetes e anteras eretos; nectário curtamente piramidal, 4-agular, ápice plano; estigma capitado. Cápsulas 1,8-2 $\mathrm{cm} \times 3,5-4,4$ $\mathrm{mm}$, verdes, 4-angulares, oblongoides, 4-aladas, glabras; pedicelo 2-4 $\mathrm{mm}$ compr.; bractéola inconspícua, na base dos frutos. Sementes ca. $3 \times 2 \mathrm{~mm}$, amarelo-acastanhadas, oblongoides, sem extremidade basal curvada; rafe proeminente, comprimento igual ao das sementes. 
Amplamente distribuída no Brasil (Zeferino et al. 2020), ocorre em 12 estados e quase todas as Regiões, sendo este, no entanto, o primeiro registro para a Bahia. F4: lagoa antropizada, separada do leito do rio São Francisco por bancos de areia (Figura 6), em matas ciliares, com influência fluvial, sobre solos argilosos a arenosos. Foi encontrada com flores e frutos em março.

Material selecionado - Bom Jesus da Lapa, próximo à igreja Nossa Senhora dos Navegantes, no rio São Francisco, 5 mar. 2019 (fl., fr.), N.X.M. Sousa et al. 593 (HURB).

Material adicional selecionado - BRASIL. SANTA CATARINA: Governador Celso Ramos, arredores, 9 fev. 1984 (fl., fr.), G. Hatschbach et al. 47596 (HUEFS, MBM*). SÃO PAULO: Presidente Epitácio, 270 m s.n.m., margem do rio Paraná, próximo da Ponte São Paulo a Mato Grosso do Sul, 11 nov. 1996, A.D. Faria et al. 96150 (IAC, SPF).

Ludwigia decurrens é a espécie da seção Pterocaulon que apresenta alas membranáceas mais evidentes, ca. $2 \mathrm{~mm}$ larg., em decorrência com a base das folhas, que se estende para os caules 4-angulares (Figura 2D) e as cápsulas 4-angulares (Figura 1E). Os frutos nascem em pequenos ramos laterais, ca. $2 \mathrm{~cm}$ compr. (Figura 1E) do caule principal, na axila das folhas, podendo ser confundido com os pedicelos de 2 $4 \mathrm{~mm}$ compr. (Figura 1E). Já em L. erecta e $L$. longifolia, as outras duas espécies da seção Pterocaulon na Bahia, os frutos nascem na axila das folhas, com pedicelo de 1-5,5 mm compr. (Figura 1I) e 6-23 mm compr. (Figura 1T), respectivamente.

\subsection{Ludwigia erecta (L.) H.Hara, J. Jap. Bot. 28: 292.} 1953.

Figuras 1I, J, 2G, H e 7; Munz (1947: 4), Ramamoorthy \& Zardini (1987: fig. 44) e Lovo \& Zappi (2018: fig 2B, C).

Nome popular: corticeiro-liso, pimenta-d'água.

Ervas a arbustos, anuais, eretos, 0,4-3 m alt.; caules muito ramificados, subcilíndricos a levemente 4angulares, glabros, ramos estreitamente 4-alados, em decorrência da base das folhas, pubérulos a glabros, esbranquiçados nas extremidades. Folhas com lâmina 3,4-16 $\times 0,5-4 \mathrm{~cm}$, face adaxial verde, a abaxial verde a verde-avermelhada, ambas glabras, elíptica, lanceolada, membranácea, ápice acuminado a agudo, base aguda, levemente decorrente nas extremidades dos ramos; pecíolo $2-14 \mathrm{~mm}$ compr.; estípula ca. $2 \mathrm{~mm}$ compr. Flores 4(5)-meras, 1-1,3 cm compr.; sépalas 3,5-5 $\times$ ca. $1 \mathrm{~mm}$, face adaxial verde, glabra, a abaxial verde a verde-avermelhada, esparsamente pubérula, lanceoladas, ápice agudo; pétalas 5-6 × 3,8 mm, obovais, ápice agudo a arredondado; estames desiguais, filetes e anteras eretos; nectário 4-angular, plano; estigma capitado. Cápsulas $1-1,8 \mathrm{~cm} \times 2-3 \mathrm{~mm}$, verdes, verde-avermelhadas a verde-vináceas, 4angulares, oblongoides, sem alas, pubérulas a glabras; pedicelo 1-5,5 $\mathrm{mm}$ compr.; bractéola inconspícua a ca. $4 \mathrm{~mm}$ compr., na base dos frutos. Sementes ca. $4 \times 2$ $\mathrm{mm}$, amarelo-acastanhadas, elipsoides, sem extremidade basal curvada; rafe proeminente, comprimento aproximadamente igual ao das sementes.
No Brasil, ocorre nos domínios fitogeográficos da Amazônia, Caatinga, Cerrado e Mata Atlântica, em 15 estados, incluindo a Bahia, e em quase todas as Regiões, sendo encontrada em áreas antrópicas, caatingas (s.str.), campos de várzea, campos rupestres, cerrados (1.s.), florestas ciliares e de galerias, florestas de terra firme e savanas amazônicas (Zeferino et al. 2020). A8, B5/6, B7, C7, C8, C9, D6, D7, D8, E3/4, E6, E7, E8, E9, E10, F6, F7, F8/9, G5, G6 e G8: Caatinga, Cerrado e Mata Atlântica (Figura 7), associada a matas ciliares, nas margens e leito de ambientes aquáticos permanentes ou temporários, como brejos, lagos, rios, riachos e cachoeiras, sobre solos arenosos, siltosos e argilosos, sendo encontrada desde ambientes limpos a moderadamente antropizados. Coletada com flores e frutos em todos os meses do ano.

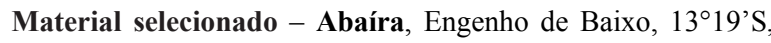
41 $49^{\circ}$ 'W, 950 m s.n.m., 25 maio 1992 (fl., fr.), W. Ganev 390 (HUEFS, SPF); Abaré, beira do rio São Francisco, $08^{\circ} 43^{\prime} \mathrm{S}, 39^{\circ} 4^{\prime} \mathrm{W}$, 321 m s.n.m., 1 nov. 2009 (fl., fr.), E. Melo et al. 7053 (HUEFS); Andaraí, estrada BA-142, margens do rio Paraguaçu, $12^{\circ} 82^{\prime} \mathrm{S}$, 41 ${ }^{\circ} 32$ 'W, 327,5 m s.n.m., 13 ago. 2016 (fl., fr.), N.X.M. Sousa 154 (EVB*, HCF*, HURB); Anguera, Lagoa 6, Km 23,1, lado SW, $12^{\circ} 10^{\prime}$ S, 39 $9^{\circ} 12^{\prime}$ W, 3 nov. 1996 (fl., fr.), E. Melo et al. 1808 (CEPEC, HUEFS, SP); Aracatu, margens do rio Riachão, 14 maio 1983, (fl., fr.), G. Hatschbach 46391 (CEPEC, MBM*); Barra, Serra do Estreito, BA-161, que liga Barra a Ibotirama, próximo da ponte do Rio Grande, $11^{\circ} 09^{\prime}$ S, $43^{\circ} 22^{\prime} \mathrm{W}, 200 \mathrm{~m}$ s.n.m., 22 ago. 1998 (fl., fr.), H.P. Bautista et al. 2477 (HUFU*); Bendengó, $2 \mathrm{~km}$ da cidade, na direção de Uauá, $09^{\circ} 57^{\prime} \mathrm{S}, 39^{\circ} 11^{\prime} \mathrm{W}, 23$ fev. 2000 (fl., fr.), A.M. Giulietti 1770 (HUEFS); Boa Vista do Tupim, rio Paraguaçu, fazenda Esperança, $12^{\circ} 30^{\prime}$ 'S, $40^{\circ} 36^{\prime} \mathrm{W}, 27$ mar. 2016, (fr.), M.P. Casaes et al. 51 (ALCB); Boninal, próximo à ponte da estrada Boninal-povoado Caititu, às margens do rio Cochó, 23 maio 2015 (fl., fr.), N.X.M. Sousa 117 (HURB, MAC); Brumado, estrada ItaquaraíIguatemi, às margens do rio São João, $13^{\circ} 58^{\prime} \mathrm{S}, 41^{\circ} 46^{\prime} \mathrm{W}, 406,5 \mathrm{~m}$ s.n.m., 20 abr. 2019 (fl., fr.), N.X.M. Sousa et al. 636 (HURB); Cabaceiras do Paraguaçu, BA-491, lago Garora, perto do Haras Manga Larga, $12^{\circ} 37^{\prime}$ S, $38^{\circ} 57^{\prime} \mathrm{W}, 7$ ago. 2012 (fl., fr.), L.Y.S. Aona et al. 1569 (HURB); Cachoeira, vale dos rios Paraguaçu e Jacuipe, porto Castro Alves, $12^{\circ} 32^{\prime}$ 'S, $39^{\circ} 05^{\prime} \mathrm{W}, 40-120 \mathrm{~m}$ s.n.m., jun. 1980 (fl., fr.), Grupo Pedra do Cavalo 263 (ALCB, CEPEC, HUEFS); Campo Formoso, fazenda Sacaíba, $10^{\circ} 21^{\prime} \mathrm{S}, 40^{\circ} 18^{\prime} \mathrm{W}, 5$ set. 81 (fl., fr.), R.P. Orlandi 523 (HRB); Casa Nova, fazenda Santarém, sítio Morrinho, área vazante do lago de Sobradinho, $09^{\circ} 36^{\prime} \mathrm{S}, 41^{\circ} 19^{\prime} \mathrm{W}$, 410 m s.n.m., 10 out. 2004 (fr.), L.P. Queiroz et al. 9659 (ESA, HUEFS); Castro Alves, próximo ao loteamento Edson C. Leão, terreno brejoso, $12^{\circ} 45^{\prime} \mathrm{S}, 39^{\circ} 26^{\prime} \mathrm{W}, 257 \mathrm{~m}$ s.n.m., 22 jul. 2015 (fl., fr.), N.X.M. Sousa 125 (HURB); Coaraci, BA-262, sentido Almadina, $5 \mathrm{~km}$ após Coaraci, $14^{\circ} 39^{\prime} \mathrm{S}, 39^{\circ} 33^{\prime} \mathrm{W}, 188 \mathrm{~m}$ s.n.m., 13 nov. 2019 (fl., fr.), N.X.M. Sousa et al. 743 (HURB); Conceição do Coité, $11^{\circ} 36^{\prime} \mathrm{S}, 39^{\circ} 16^{\prime} \mathrm{W}, 13$ jan. 2018 (fr.), G. Costa et al. 3230 (HURB); Conde, fazenda de Bu, 12 $2^{\circ} 03^{\prime} \mathrm{S}, 37^{\circ} 42^{\prime} \mathrm{W}, 19$ mar. 1996 (fr.), T. Jost et al. 238 (HRB); Contendas do Sincorá, lagoa e campo alagado próximo à sede da FLONA, $13^{\circ} 55^{\prime} \mathrm{S}, 41^{\circ} 06^{\circ} \mathrm{W}, 388 \mathrm{~m}$ s.n.m., 6 fev. 2015 (fr.), L.Y.S. Aona et al. 3880a (HURB); Dom Macedo Costa, primeira entrada à esquerda antes da cidade, lagoa, 10 fev. 2015 (fl., fr.), G. Costa et al. 1206 (HURB); Feira de Santana, Lagoa 2, $12^{\circ} 16^{\prime}$ S, 39 39' 'W, 174 m s.n.m., 28 jan. 1997 (fl., fr.), E. Melo et al. 1999 (HUEFS, SP); Governador Mangabeira, 
lagoa próxima à Barragem Pedra do Cavalo, 12³3'S, 3902'W, 149 m s.n.m., 18 set. 2016 (fr.), N.X.M. Sousa et al. 206 (HURB); Iaçu, fazenda Suíbra, $18 \mathrm{~km}$ a leste da cidade, seguindo a ferrovia, $12^{\circ} 43^{\prime} \mathrm{S}$, 4007'W, 13 mar. 1985 (fl., fr.), L.R. Noblick 3653 (CEPEC, HUEFS, $\mathrm{SP}$ ); Ibiassucê, a $2 \mathrm{~km}$ da cidade, lago à direita da estrada, $14^{\circ} 15^{\prime} \mathrm{S}$, $42^{\circ} 15^{\prime} \mathrm{W}, 542,5$ ms.n.m., 4 mar. 2019 (fl., fr.), N.X.M. Sousa et al. 587 (HURB); Ilhéus, Campus da UESC, Km 16, BR-415, rodovia Ilhéus-Itabuna, a oeste da Área de Reserva, $14^{\circ} 48^{\prime} \mathrm{S}, 39^{\circ} 10^{\prime} \mathrm{W}, 40 \mathrm{~m}$ s.n.m., 30 jan. 1996, (fr.), L.A.M. Silva et al. 3328 (CEPEC, HUEFS); Itaberaba, BR-242, aproximadamente $15 \mathrm{~km}$ depois da sede, sentido Seabra, Lagoa, $12^{\circ} 30^{\prime}$ 'S, $40^{\circ} 26^{\prime}$ 'W, 332,5 m s.n.m., 16 jun. 2018, (fr.), N.X.M. Sousa et al. 329 (HURB); Itiúba, Lagoa da Eugenia ao S, próximo de Camaleão, 1040'S, 3943’ W, 300 m s.n.m., 21 fev. 1974 (fl., fr.), R.M. Harley 16280 (CEPEC); Jacobina, Serra de Jacobina, $11^{\circ} 10^{\prime} \mathrm{S}, 40^{\circ} 29^{\prime} \mathrm{W}, 1010 \mathrm{~m}$ s.n.m., 12 jul. 97 (fl., fr.), M. L. Guedes et al. 5074 (ALCB, HUEFS); Jaguarari, Juacema, fazenda Pé de Serra, $10^{\circ} 10^{\prime} \mathrm{S}, 40^{\circ} 13^{\prime} \mathrm{W}, 618 \mathrm{~m}$ s.n.m., 28 jul. 2005 (fl., fr.), D.S. Carneiro-Torres et al. 356 (HUEFS, HUESB); Juazeiro, rio São Francisco, margem direita, povoado Alagadiço, Chácara Jardim das Pleiades, 09²8'S, 40³5'W, 373 m s.n.m., 30 maio 2011 (fl., fr.), J.V.A. Ferreira et al. 61 (HVASF); Lagoa Real, povoado Tapera, na margem do rio São João, $14^{\circ} 14^{\prime}$ 'S, $42^{\circ} 15^{\prime} \mathrm{W}, 545,5$ m s.n.m., 4 mar. 2019 (fl., fr.), N.X.M. Sousa et al. 585 (HURB); Livramento de Nossa Senhora, BA-572, povoado Fazenda Campos, 135'ㅇ, 41 ${ }^{\circ} 51$ 'W, alt.: 443,5 m s.n.m., 20 abr. 2019 (fl., fr.), N.X.M. Sousa et al. 623 (HURB); Maracás, abr. 2011, (fl., fr.), E.P. Queiroz 4988 (HRB); Mata de São João, 12³4'S, 38 ${ }^{\circ} 00^{\prime} \mathrm{W}, 12$ jan. 2013 (fr.), F.S. Gomes et al. 1220 (ALCB); Monte Santo, $10^{\circ} 26^{\prime} \mathrm{S}, 39^{\circ} 19^{\prime} \mathrm{W}$, 11 jan. 2006 (fr.), M.L. Guedes et al. 12110 (ALCB); Morro de Chapéu, fazenda São João dos Brejões, rio Salitre, $11^{\circ} 15^{\prime} \mathrm{S}$, 41 ${ }^{\circ} 05^{\prime}$ 'W, 726 m s.n.m., 14 abr. 2007 (fl., fr.), E. Melo et al. 4710 (HUEFS); Muritiba, Pedra do Cavalo, rio Paraguaçu, $12^{\circ} 35^{\prime} \mathrm{S}$, 3900'W, 336 m s.n.m., 24 jul. 2012 (fl., fr.), L.Y.S. Aona et al. 1507 (HURB); Nazaré das Farinhas, 13 dez. 2017 (fr.), L.D. Souza s.n. (HURB 17851); Piatã, $13^{\circ} 04^{\prime} \mathrm{S}, 41^{\circ} 53^{\prime} \mathrm{W}, 19$ set. 2004 (fr.), M.L. Guedes et al. 11399 (ALCB); Piritiba, 11 ${ }^{\circ} 43$ 'S, 40³3'W, 30 maio 1980 (fl., fr.), L. R. Noblik et al. 1872 (HUEFS, HRB); Quijingue, Serra das Candeias, ca. de $5 \mathrm{~km}$ a oeste do povoado Quixaba do Mandacaru, limite com o município de Tucano, $10^{\circ} 55^{\prime} \mathrm{S}, 39^{\circ} 04^{\prime} \mathrm{W}$, 400-630 m s.n.m., 8 jul. 2006 (fl., fr.), D. Cardoso et al. 1353 (HUEFS); Rafael Jambeiro, BR-242, Km 125, à direita, 3 km após a entrada de Rafael Jambeiro, Lagoa, 12 $322^{\prime} \mathrm{S}, 39^{\circ} 34^{\prime} \mathrm{W}, 176 \mathrm{~m}$ s.n.m., 16 jun. 2018 (fr.), N.X.M. Sousa et al. 322 (HURB); Ribeira do Pombal, 19 maio 1981 (fl., fr.), G. Pinto 132 (CEPEC, HRB, HUEFS); Rio de Contas, estrada para Jussiape, 27 maio 1991 (fr.) F. Navarro s.n. (ALCB 23068); Santa Terezinha, Recôncavo Sul, margem do rio Paraguaçu, 12 ${ }^{\circ} 46^{\prime} \mathrm{S}, 39^{\circ} 31^{\prime} \mathrm{W}, 7$ maio 2016 (fl., fr.), M.L. Guedes et al. 24623 (ALCB); Santo Amaro, próximo ao lago, $12^{\circ} 33^{\prime}$ S, 3840'W, 22 set. 2014 (fl., fr.), N.X.M. Sousa et al. 36 (HURB); Santo Antônio de Jesus, córrego em estrada vicinal, BR101, lado esquerdo, sentido Teolândia, $13^{\circ} 00^{\prime} \mathrm{S}, 39^{\circ} 15^{\prime} \mathrm{W}, 29$ jan. 2015 (fl., fr.), N.X.M. Sousa et al. 112 (ASE*, FURB*, HURB); Sento Sé, Beira da Lagoa, estrada para área Colomi, rio São Francisco, 0946'S, 42 ${ }^{\circ}$ 'W, 390 m s.n.m., 17 dez. 2007 (fl., fr.), C. Correia et al. 370 (HUEFS); Sapeaçu, 4-4,5 km, em direção a Castro Alves, lago à esquerda, 5 out. 2010 (fl., fr.), L.Y.S. Aona et al. 1373 (HURB); Saubara, lago à beira da estrada, 26 nov. 2014 (fl., fr.), N.X.M. Sousa et al. 50 (HURB); Serra Preta, Distrito de Bravo, lagoa temporária ao lado da estrada, $12^{\circ} 10^{\prime} \mathrm{S}, 39^{\circ} 27^{\prime} \mathrm{W}, 247 \mathrm{~m}$ s.n.m., 15 jul. 2018 (fl., fr.), N.X.M. Sousa et al. 507 (HURB); Tabocas do
Brejo Velho, $5 \mathrm{~km}$ ao $\mathrm{N}$ de Tabocas e $10 \mathrm{~km}$ ao $\mathrm{NW}$ de Serra Dourada, 12 $39^{\prime}$ 'S, $44^{\circ} 02^{\prime} \mathrm{W}, 500$ m s.n.m., 1 maio 1980 (fl., fr.), R.M. Harley 21982 (CEPEC, SPF); Tanhaçu, povoado Sussuarana, às margens do Rio de Contas, $14^{\circ} 09^{\prime} \mathrm{S}, 41^{\circ} 12^{\prime} \mathrm{W}, 332,5$ ms.n.m., 20 abr. 2019 (fl., fr.), N.X.M. Sousa et al. 641 (HURB); Tucano, $10^{\circ} 55^{\prime} \mathrm{S}, 39^{\circ} 4^{\prime} \mathrm{W}$, s.d. (fl., fr.), G. Costa 365 (HUEFS); Umburanas, Piemonte da Diamantina, $12^{\circ} 06^{\prime}$ S, $39^{\circ} 50^{\prime} \mathrm{W}, 262$ m s.n.m., 9 abr. 2013 (fl., fr.), M.L. Guedes et al. 20614 (ALCB); Xique-Xique, Guaximim, a 4 km de Xique-Xique, 1048'S, 4243’W, 23 jun. 1996 (fl., fr.), M.L. Guedes et al. 2953 (ALCB, CEPEC, HRB, HUEFS, SPF).

Ludwigia erecta, na seção Pterocaulon, apresenta fruto 4-angular, oblongoide, não alado, e sementes elipsoides não envolvidas pelo endocarpo (Figuras 1I, J), e apresenta pétalas obovais, com ápice agudo a arredondado, e estames eretos (Figuras 2G, H). Caracteres importantes que a separam de L. hyssopifolia e L. octovalvis são apresentados nos comentários de $L$. hyssopifolia.

\subsection{Ludwigia longifolia (DC.) H.Hara, J. Jap. Bot. 28:} 293. 1953.

Figuras 1T, U, 3F, G e 11; Munz (1947: fig. 6), Ramamoorthy \& Zardini (1987: fig. 37) e Zardini \& Raven (1997: fig. 11).

Ervas a subarbustos, anuais, eretos, 0,6-2 m alt.; caules ramificados, levemente 4-angulares, glabros, ramos estreitamente 4-alados, em decorrência à base das folhas, pubérulos e esbranquiçados nas extremidades. Folhas com lâmina 2,9-16,2 × 0,2-3 cm, face adaxial verde, a abaxial verde a verde-avermelhada, ambas glabras, estreito-elíptica, lanceolada a linear-lanceolada, membranácea, ápice acuminado a agudo, base aguda, levemente decorrente nas extremidades dos ramos; pecíolo 0,5-1,9 $\mathrm{mm}$ compr. (ou folhas sésseis); estípula 3-4 mm compr. Flores 4-meras, 4-4,6 cm compr.; sépalas 1,2-1,8 cm $\times$ 4-6 mm, face adaxial verde, a abaxial verde a verde-avermelhada, ambas glabras, lanceoladas, ápice acuminado a agudo; pétalas 1,9-2,2 $\times$ 1,9-2,2 cm, orbiculares, ápice arredondado a emarginado; estames subiguais, filetes curtos, curvados, anteras levemente curvadas, aproximando-se das pétalas; nectário curtamente piramidal, 4-agular, ápice plano; estigma subcapitado. Cápsulas $1,2-3,2 \mathrm{~cm} \times 4$ $5 \mathrm{~mm}$, verdes, verde-avermelhadas a verde-vináceos, 4angulares, oblongoides, estreitamente 4-aladas, glabras; pedicelo 6-23 mm compr.; bractéola 4-6 $\mathrm{mm}$ compr., na base dos frutos. Sementes ca. $6 \times 2 \mathrm{~mm}$, amareloacastanhadas, oblongoides, com extremidade basal curvada; rafe proeminente, com camada corticosa exposta sobre a extremidade basal curvada, comprimento igual ao das sementes.

Ocorre na Caatinga, Cerrado, Mata Atlântica, Pampa, Pantanal, nas Regiões Sul, Sudeste, em Goiás, Mato Grosso do Sul e Distrito Federal, além da Bahia (Zeferino et al. 2020). E3, E6, F6 e I8: no oeste do estado e na Chapada Diamantina, Mata Atlântica, Caatinga, Cerrado (Figura 11), em restingas e florestas atlânticas, em formações savânicas e campestres, 
ocorrendo em ambientes úmidos a alagados, nas matas ciliares, nas margens e leito de rios, riachos e cachoeiras, sobre solos arenosos, siltosos e entre as rochas. Coletada com flores e frutos em março, junho, julho, outubro e novembro, e com frutos em agosto.

Material selecionado - Andaraí, estrada BA-145, margens do rio Santo Antônio, 12 ${ }^{\circ} 75^{\prime}$ 'S, 41 $41^{\circ} 32^{\prime} \mathrm{W}, 307,5$ m s.n.m., 13 ago. 2016 (fr.), N.X.M. Sousa 150 (HURB); Boninal, Cachoeira da Cotia, povoado Ministro, $12^{\circ} 48^{\prime}$ 'S, $41^{\circ} 47^{\prime} \mathrm{W}, 973,5$ m s.n.m., 12 out. 2018 (fl., fr.), N.X.M. Sousa et al. 517 (HURB); Ibicoara, Cascavel, Lagoa Encantada, entre Ibicoara e Cascavel, $13^{\circ} 18^{\prime} \mathrm{S}, 41^{\circ} 19^{\prime} \mathrm{W}, 1008 \mathrm{~m}$ s.n.m., 21 mar. 1999 (fl., fr.), R.M. Harley et al. 53555 (ALCB, HRB, HUEFS); Mucugê, $13^{\circ} 01^{\prime}$ 'S, $41^{\circ} 25^{\prime} \mathrm{W}, 1000$ m s.n.m., 2 nov. 2007 (fl., fr.), E. Melo et al. 5365 (HUEFS); Piatã, próximo à cidade, nas margens do Rio de Contas, lado direito no sentido Boninal-Piatã,

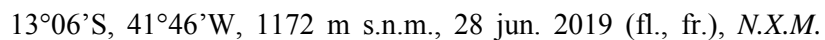
Sousa et al. 729 (HURB); Porto Seguro, Km 16 da rodovia Porto Seguro-Eunapólis, Vale do Rio Buranhem, 17 jul. 1981 (fl., fr.), H.S. Brito et al. 39 (CEPEC, HRB); Rio de Contas, 2,5-5 km ao sul de Rio de Contas, a oeste da estrada para Livramento, nas margens do rio Brumado, rochoso, com corredeiras, $13^{\circ} 36^{\prime} \mathrm{S}, 41^{\circ} 50^{\prime} \mathrm{W}, 980 \mathrm{~m}$ s.n.m., 28 mar. 1977 (fl., fr.), R.M. Harley 20109 (NY*, SPF, UEC); São Desidério, assentamento Thainá, $12^{\circ} 36^{\prime} \mathrm{S}, 44^{\circ} 51^{\prime} \mathrm{W}, 1$ jul. 2001 (fl., fr.), L. J. Alves et al. 253 (ALCB).

Ludwigia longifolia apresenta ampla variação morfológica. Na margem de rios, entre rochas de cachoeiras e em solos arenosos nos períodos chuvosos, apresenta-se como erva decumbente, com folhas verdes (Figura 3F), mais largas, frutos maiores, verdes e com alas mais largas (Figura 1T). No entanto, nos períodos de secas, apresenta-se menor, com folhas verdes a verde-avermelhadas e frutos mais estreitos, verde-avermelhados a verde-vináceos, quase sem alas, já as sementes são oblongoides, com a extremidade basal curvada e a rafe proeminente com camada corticosa exposta sobre a extremidade basal curvada (Figura 1U).

Ludwigia sect. Seminuda P.H.Raven, Reinwardtia 6(4): 334. 1964.

Caules cilíndricos ou subcilíndricos, eretos e/ou levemente escandentes, com raízes laterais fibrosas e raros pneumatóforos brancos. Folhas alternas, com margens inteiras. Corola amarela; androceu diplostêmone. Cápsulas subcilíndricas, com paredes finas, irregularmente deiscentes. Sementes unisseriadas envolvidas parcialmente pelo endocarpo corticoso em forma de ferradura; rafe com camada corticosa exposta. Números cromossômicos: $\mathrm{n}=16,24,32,40$.

$\mathrm{Na}$ Bahia, está representada por L. affinis, $L$. leptocarpa e L. quadrangularis.

\subsection{Ludwigia affinis (DC.) H.Hara, J. Jap. Bot. 28:} 291. 1953.

Figuras 1A, B e 5; Munz (1947: fig. 33), Zardini \& Raven (1997: fig. 1) e Cumana Campos (2010: fig. 1).

Ervas a subarbustos, anuais, eretos, levemente escandentes, 0,8-1,5 m alt.; caules muito ramificados, hirsutos, ramos densamente hirsutos e acastanhados nas extremidades. Folhas com lâmina 1,4-5,9 × 0,6-2,9 cm, face adaxial verde, glabrescente, a abaxial verde a verde-avermelhada, hirsuta a pubescente, oval, elíptica a largo-elíptica, membranácea, ápice agudo a obtuso, base aguda a arredondada; pecíolo 1,5-8 mm compr. (ou folhas sésseis); estípula inconspícua. Flores 5(6)-meras, 1,6-1,8 cm compr.; sépalas 4-6,2 × 1-3 mm, face adaxial verde, glabrescente, a abaxial verde a verdeavermelhada, hirsuta a pubescente, lanceoladas, ápice agudo; pétalas 6-8 × 6-8 $\mathrm{mm}$, obovais a orbiculares, ápice arredondado; estames desiguais, filetes e anteras eretos; nectário convexo, ápice plano; estigma capitado. Cápsulas 1,3-3 $\times$ 0,1-2,9 $\mathrm{cm}$, verdes a verdeavermelhadas, cilíndricas a subcilíndricas, hirsutas; pedicelo 1-4 mm compr.; bractéola inconspícua, na base dos frutos. Sementes ca. $6 \times 3 \mathrm{~mm}$, amareloacastanhadas, oblongo-ovoides; rafe proeminente, comprimento igual ao das sementes.

Ocorre na Amazônia, Caatinga, Cerrado e Mata Atlântica, em 12 estados, em quase todas as Regiões do Brasil (Zeferino et al. 2020), sendo este, no entanto, o primeiro registro para a Bahia. F3: Chapadão Ocidental da Bahia (Figura 5), em vegetação típica de caatingas (s.str.) e cerrados (s.1.), florestas de galerias e matas ciliares, nas margens e bancos de areia do Rio Corrente, em solos arenosos a argilosos. Coletada com flores e frutos em abril.

Material selecionado - Correntina, ca. $9 \mathrm{~km}$ a SE de Correntina, na rodovia para Jaborandi, $13^{\circ} 20^{\prime} \mathrm{S}, 44^{\circ} 38^{\prime} \mathrm{W}, 550 \mathrm{~m}$ s.n.m., 27 abr. 1980 (fl., fr.), R.M. Harley 21847 (CEPEC, K*, NY*, SPF, UEC, US*); ib., Chapadão Ocidental da Bahia, margens e bancos de areia do Rio Corrente, próximo a Correntina, $13^{\circ} 20^{\prime} \mathrm{S}$, 44³8'W, 580 m s.n.m., 23 abr. 1980 (fl., fr.), R.M. Harley 21641 (CEPEC).

Material adicional selecionado - BRASIL. MATO GROSSO: Aripuanã, Serra Morena, margem da MT-420, a cerca de $55 \mathrm{~km}$ da cidade, em direção a Juruena, 10¹8'S, 5900’W, 11 jul. 1997 (fl., fr.), G.F. Árbocz et al. 4277 (ESA, HURB); Novo Mundo, Parque Estadual Cristalino, extremo nordeste do Parque, subindo o rio Cristalino, $09^{\circ} 28^{\prime} \mathrm{S}, 55^{\circ} 42^{\prime} \mathrm{W}, 242 \mathrm{~m}$ s.n.m., 27 ago. 2008 (fl., fr.), D.C. Zappi et al. 1468 (NY*, SPF).

Ludwigia affinis é confundida com L. leptocarpa em relação ao tipo e coloração do indumento do caule, folhas, sépalas e frutos. Em L. affinnis, os ramos são hirsutos, anguloso-curvados, segmentados e acastanhados, com extremidade apical densamente hirsuta (vs. ramos densamente pilosos nas extremidades, eretos e alvos em L. leptocarpa). As folhas e sépalas de L. affinis apresentam a face abaxial hirsuta a pubescente (vs. pilosa a pubescente em L. leptocarpa); as folhas são ovais, elípticas a largo-elípticas, agudas a arredondadas na base (vs. elípticas, lanceoladas a oblanceoladas, atenuadas na base). Os frutos em L. affinis são hirsutos (vs. pilosos a glabros), com tricomas mais curtos (0,5-2 $\mathrm{mm}$ vs. 1,7-3,7 mm compr.), e as sementes envolvidas parcialmente pelo endocarpo corticoso em forma de ferradura oblongo-ovoides (Figura 1A, B) em vez de oblongo-achatadas (Figura 1R, S), como em $L$. leptocarpa. 


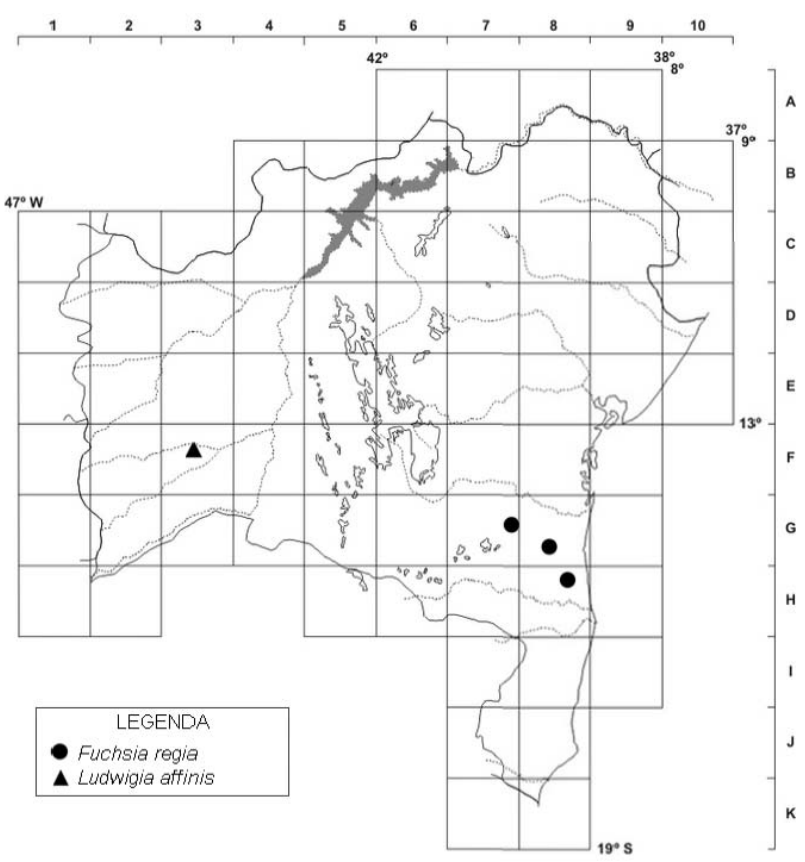

Figura 5. Mapa de distribuição geográfica de Fuchsia regia e Ludwigia affinis no estado da Bahia.

2.18. Ludwigia leptocarpa (Nutt.) H.Hara. J. Jap. Bot. 28: 292. 1953.

Figuras 1Q-S, 3E e 10; Munz (1947: fig. 32), Zardini \& Raven (1997: fig. 10) e Lovo \& Zappi (2018: fig. 3 A, B).

Ervas a subarbustos, anuais ou perenes, eretos, $0,3-$ $2 \mathrm{~m}$ alt.; caules muito ramificados, pilosos, pubérulos a glabrescentes, ramos densamente pilosos e esbranquiçados nas extremidades. Folhas com lâmina 2,4-13 × 0,6-3,7 cm, face adaxial verde, glabrescente, a abaxial verde a verde-avermelhada, pilosa a pubescente, elíptica, lanceolada a oblanceolada, membranácea, ápice agudo a obtuso, base atenuada; pecíolo $2-18 \mathrm{~mm}$ compr.; estípula inconspícua. Flores 5(-8)-meras, 2,3$2,5 \mathrm{~cm}$ compr.; sépalas $2-14 \times 3-4 \mathrm{~mm}$, face adaxial verde, glabrescente, a abaxial verde a verdeavermelhada, pilosa a pubescente, lanceoladas, ápice agudo; pétalas $0,3-1,6 \times \mathrm{ca}$. $1 \mathrm{~cm}$, orbicular-obovais, ápice arredondado, emarginado; estames desiguais, filetes e anteras eretos; nectário convexo, ápice plano; estigma capitado. Cápsulas 2-4,5 $\mathrm{cm} \times 2-4 \mathrm{~mm}$, verdes a verde-avermelhadas, subcilíndricas, pilosas a glabras; pedicelo 2,6-17 $\mathrm{mm}$ compr.; bractéola ca. $0,5 \mathrm{~mm}$ compr., na base dos frutos. Sementes ca. $7 \times 2 \mathrm{~mm}$ compr., amarelo-acastanhadas, oblongo-achatadas; rafe proeminente, comprimento aproximadamente igual ao das sementes.

Amplamente distribuída no Brasil (Zeferino et al. 2020). B6, B7, C9, D6, D7, D9/10, E3, E4, E6, E7, E8, E9, F3, F7, F8, F9, G4, G8, H7, H8 e I8: Caatinga, Cerrado e Mata Atlântica (Figura 10), em restingas, associadas a matas ciliares, nas margens e leito dos ambientes aquáticos permanentes ou temporários, como brejos, córregos, lagos, rios, riachos e cachoeiras, sobre solos arenosos, siltosos e argilosos, desde ambientes

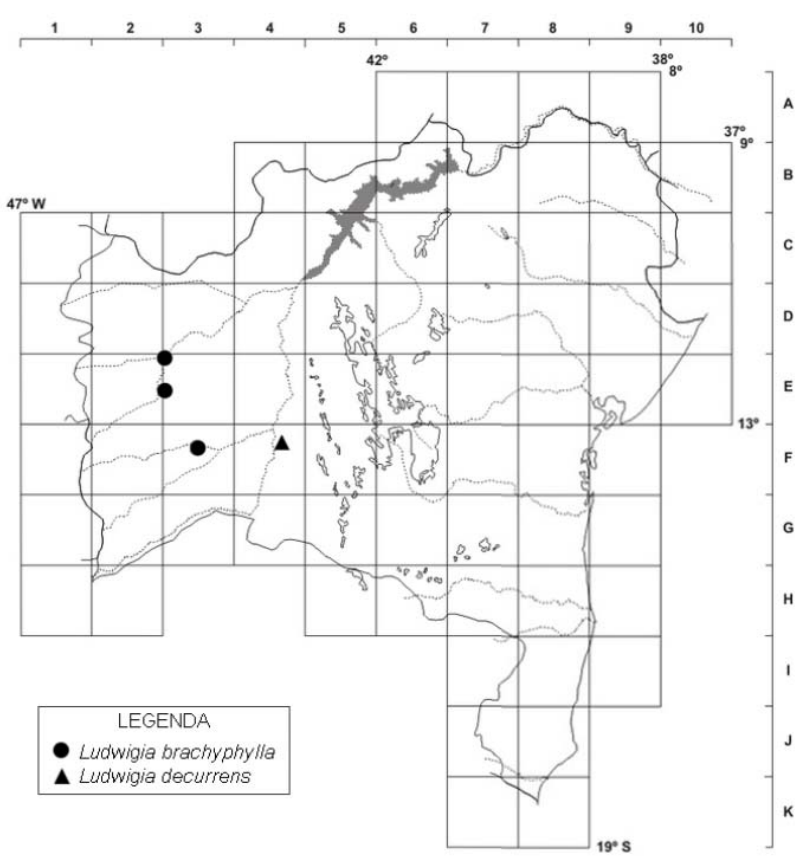

Figura 6. Mapa de distribuição geográfica de Ludwigia brachyphylla e L. decurrens no estado da Bahia.

limpos a moderadamente antropizados. Coletada com flores e frutos em todos os meses do ano.

Material selecionado - Abaré, próximo à margem do rio São Francisco, $08^{\circ} 72^{\prime} \mathrm{S}, 39^{\circ} 11^{\prime} \mathrm{W}, 8$ nov. 2018 (fl., fr.), M.L. Guedes et al. 31046 (ALCB); Alagoinhas, fazenda Pimentel, Lagoa de Dona Maria, povoado Catuzinho, 4 set. 2007 (fl., fr.), N.G. Jesus et al. 2293 (ALCB, HUEFS, HUNEB); Andaraí, Marimbus, $12^{\circ} 45^{\prime} \mathrm{S}, 41^{\circ} 17^{\prime} \mathrm{W}$, 4 out. 2003 (fl., fr.), D.S. Carneiro-Torres et al. 258 (HUESB, HURB); Anguera, Lagoa 5, $12^{\circ} 11^{\prime}$ 'S, 399'W, 180 m s.n.m., 16 fev. 1997 (fl., fr.), E. Melo et al. 2019 (HUEFS); Aramari, 4 nov. 2009 (fl., fr.), I.M.O. Carvalho 10 (HUNEB); Aurelino Leal, nas margens ao lado da ponte do Rio de Contas, 15 nov. 2019 (fl., fr.), N.X.M. Sousa 754 (HURB); Barra, Serra do Estreito, BA-161que liga Barra a Ibotirama, próximo da ponte do Rio Grande, $11^{\circ} 09^{\prime} \mathrm{S}, 43^{\circ} 22^{\prime} \mathrm{W}$, 200 m s.n.m., 22 ago. 1998 (fl.), H.P. Bautista et al. 2478 (HRB); Barreiras, área da UFBA, margem do Rio Grande, 10 jun. 2007 (fl., fr.), C.B.N. Costa \& J. Costa 1376 (BRBA); Boninal, margens do rio Cochó, próximo da ponte da estrada Boninal-povoado Caititu, 25 abr. 2014, (fl., fr.), N.X.M. Sousa 13 (ALCB, HURB); Cachoeira, brejo atrás do posto Lagoa Encantada, $12^{\circ} 35^{\prime} \mathrm{S}, 38^{\circ} 56^{\prime} \mathrm{W}, 23$ mar. 2010 (fl., fr.), L.Y.S. Aona et al. 1221c (HURB); Camaçari, Arembepe, entre o bairro Robalo e a aldeia Hippie, $12^{\circ} 56^{\prime}$ 'S, 38²1 'W, 2-9 m s.n.m., 3 fev. 2006 (fl., fr.), D. Cardoso et al. 1002 (HUEFS); Campo Formoso, Canavieira, cerca à margem direita da estrada de terra em direção ao distrito de Poços, $10^{\circ} 30^{\prime}$ S , 40 ${ }^{\circ} 19^{\prime} \mathrm{W}, 541 \mathrm{~m}$ s.n.m., 7 dez. 2011 (fl., fr.), T.S. Oliveira et al. 122 (HURB, HVASF); Candeias, BR-324, Km 40, fazenda Lagoa Azul, propriedade do Sr. Etevaldo, 12³8'S, 38²8'W, 21 out. 2004 (fl., fr.), K.R.B. Leite 464 (HUEFS); Carinhanha, Médio São Francisco, foz do rio Carinhanha, $14^{\circ} 20^{\prime}$ 'S, 434ㄱ'W, 26 maio 2007 (fl., fr.), M.L. Guedes et al. 13538 (ALCB, BRBA, HUEFS); Castro Alves, Lagoa de Jorge Almeida, 2 nov. 1994 (fr., fl.), C.A.L. Carvalho 96 (HUEFS); Conceição do Almeida, 15 fev. 2012 (fr., fl.), G. Costa et al. 647 (HURB); Conde, BA-099, margem do rio Crumaí, $11^{\circ} 48^{\prime}$ S, $37^{\circ} 37^{\prime}$ W, 10 m s.n.m., 23 fev. 2019 (fl.), N.X.M. Sousa et al. 565 (HURB); Correntina, Chapadão 


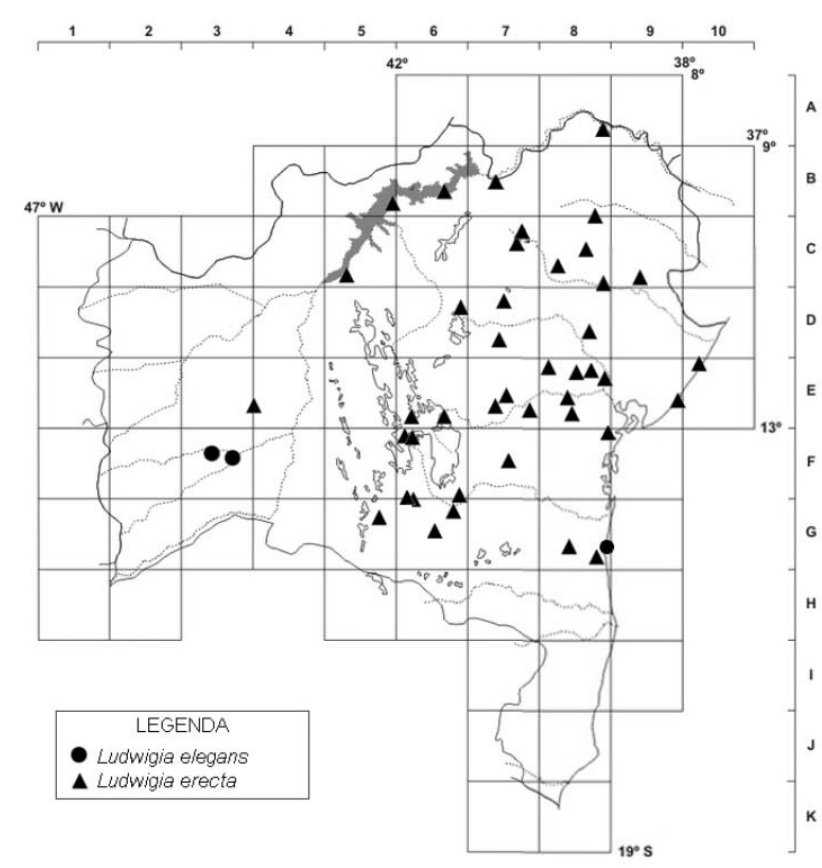

Figura 7. Mapa de distribuição geográfica de Ludwigia elegans e L. erecta no estado da Bahia.

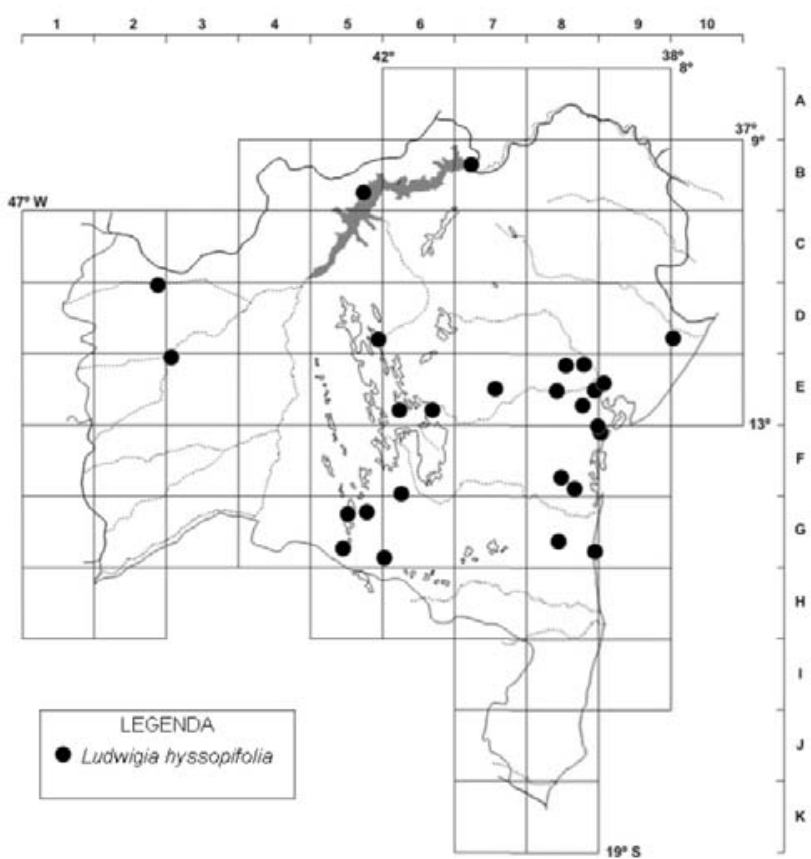

Figura 9. Mapa de distribuição geográfica de Ludwigia hyssopifolia no estado da Bahia.

Ocidental da Bahia, margens e bancos de areia do rio Corrente, próximo a Correntina, $13^{\circ} 20^{\prime}$ 'S, $44^{\circ} 38^{\prime} \mathrm{W}, 580 \mathrm{~m}$ s.n.m., 23 abr. 1980 (fl., fr.), R.M. Harley 21691A (SP, SPF); Cruz das Almas, Fonte do Doutor, sentido Baixa da Sapucaia, Bica do Tororó (Jorrinho), 28 out. 2008 (fl., fr.), L.Y.S. Aona 1201a (HURB); Dom Macedo Costa, primeira entrada à esquerda antes da cidade, lagoa, 10 fev. 2015 (fl., fr.), G. Costa et al. 1207 (HURB); Entre Rios, Restinga de Massarandupió, após o rio, $12^{\circ} 19^{\prime} \mathrm{S}$; $37^{\circ} 52^{\prime} \mathrm{W}, 11$ jan. 2001 (fl., fr.), M.R. Fonseca et al. 42 (HUNEB); Esplanada, sentido Entre Rios, lago ao lado da BA-101, 24 fev. 2019, (f1., fr.), N.X.M. Sousa et al.

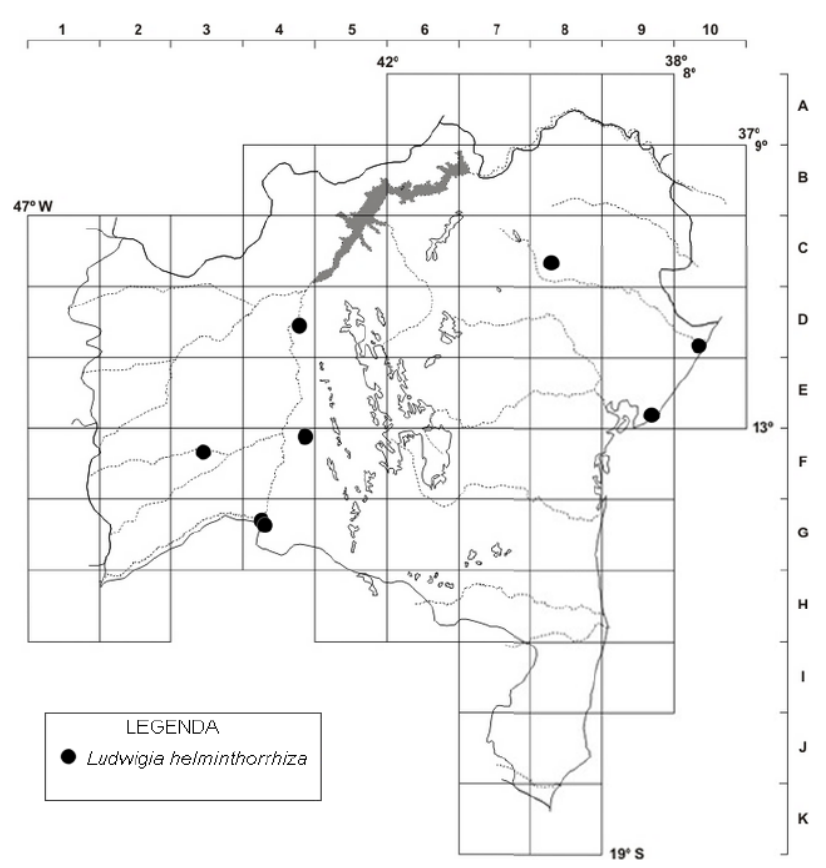

Figura 8. Mapa de distribuição geográfica de Ludwigia helminthorrhiza no estado da Bahia.

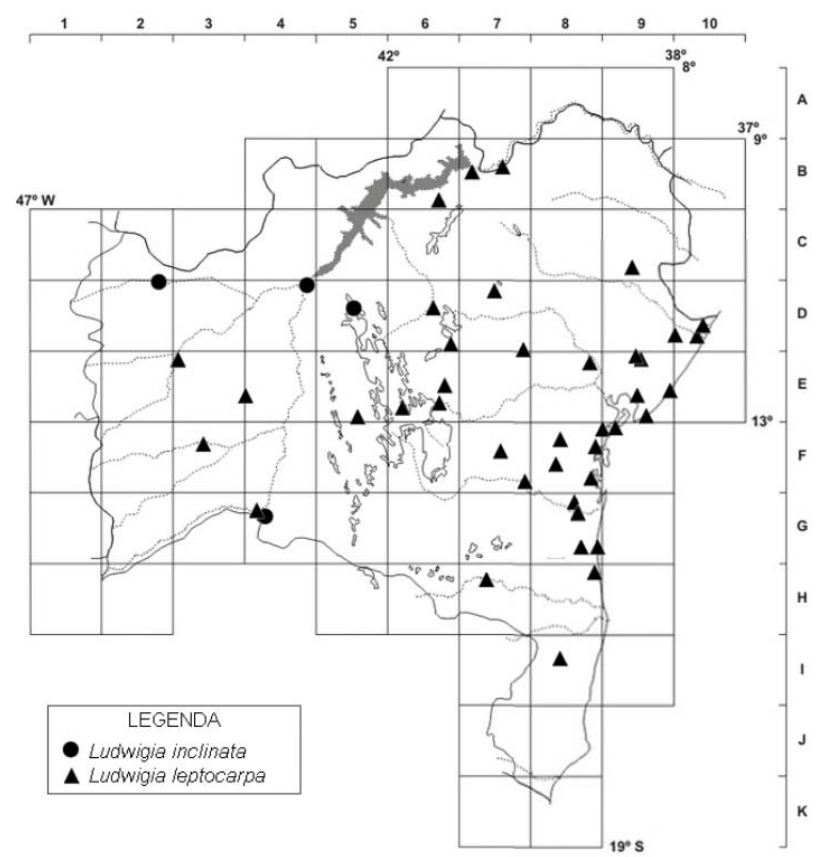

Figura 10. Mapa de distribuição geográfica de Ludwigia inclinata e L. leptocarpa no estado da Bahia.

577 (HURB); Eunápolis, Conglomerado, 2 dez. 2014 (fl., fr.), R.C. Paulino 98 (CEPEC); Floresta Azul, Represa Salomé, 1450’'S, 39³8'W, 14 jun. 2002 (fl., fr.), E.A. Rocha et al. 943b (CEPEC, UESC); Ibirapitanga, nas margens ao lado da ponte do rio Oricó, 15 nov. 2019 (fl., fr.), N.X.M. Sousa et al. 761 (HURB); Igrapiúna, Litoral Sul, Rodotec-Comunidade Vargído, $13^{\circ} 49^{\prime} \mathrm{S}, 39^{\circ} 08^{\prime} \mathrm{W}, 21$ dez. 2003 (fl., fr.), L.O. Magalhães 24 (ALCB); Ilhéus, Pontal para Olivença, 10 fev. 1985 (fl., fr.), E. Zardini et al. 2239 (CEPEC); Itabuna/Ilhéus, 5 abr. 1965, (fl., fr.), R.P. Belém et al. 692 (CEPEC); Itambé, nas margens do rio Prado, ao lado da rua Manoel da Paixão, 


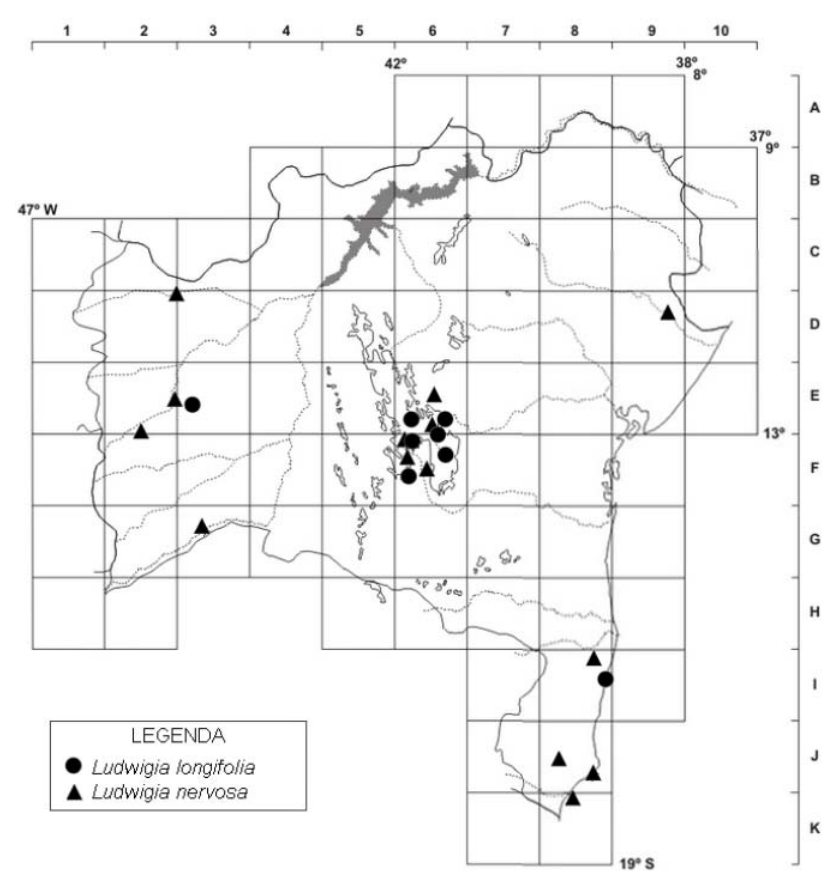

Figura 11. Mapa de distribuição geográfica de Ludwigia longifolia e L. nervosa no estado da Bahia.

$15^{\circ} 15^{\prime}$ 'S , 40³7'W, 316 m s.n.m., 12 nov. 2019 (fr.), N.X.M. Sousa et al. 740 (HURB); Jacobina, Serra do Tombador, $11^{\circ} 14^{\prime} \mathrm{S}, 40^{\circ} 43^{\prime} \mathrm{W}$, 910 m s.n.m., 31 mar. 1996 (fl., fr.), A.M. Giulietti et al. 2681 (CEPEC, HRB); Jaguaripe, depois da área da Petrobrás, 27 set. 2014 (fl., fr.), N.X.M. Sousa 40 (HURB); Jandaíra, BA-099, margem do

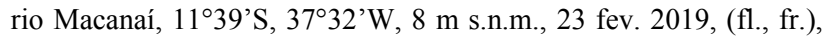
N.X.M. Sousa et al. 559 (HURB); Jequié/Ubaitaba, 9 fev. 1985 (fl., fr.), E. Zardini et al. 2235 (CEPEC); Jiquiriçá, Cachoeira dos Amores, 13²16'S, 39³4'W, 28 mar. 2015, (fr.), G. Costa et al. 1262 (HUEFS, HURB); Juazeiro, Reserva Florestal da Agrovale, 09²4'S, 40²3'W, 375 m s.n.m., 6 set. 2009 (fl., fr.), E. Melo 6440 (HUEFS); Lençóis, BR-242, nas margens do rio Utinga, povoado São José, sentido Seabra, lado esquerdo, $12^{\circ} 30^{\prime} \mathrm{S}, 41^{\circ} 12^{\prime} \mathrm{W}, 318,5 \mathrm{~m}$ s.n.m., 16 jun. 2018, (fr.), N.X.M. Sousa et al. 341 (HURB); Macaúbas, barragem do rio Paramirim, $12^{\circ} 56^{\prime} \mathrm{S}, 42^{\circ} 26^{\prime} \mathrm{W}, 549 \mathrm{~m}$ s.n.m., 12 out. 2007 (fl., fr.), A.A. Conceição et al. 2576 (HUEFS); Maracás, Sudoeste, margem do Rio de Contas, área de captação de da Embasa, 1326'S, 40²5'W, 23 out. 2012 (fl., fr.), M.L. Guedes et al. 20192 (ALCB); Mata de São João, Sauípe, fazenda Sauípe da Construtora N. Odebrecht, 25 fev. 1986 (fl., fr.), H.P. Bautista et al. $1047 a$ (CEPEC); Morro do Chapéu, balneário Novo Tareco, Represa do Rio Tareco, $11^{\circ} 24^{\prime}$ S, $41^{\circ} 22^{\prime} \mathrm{W}, 700$ m s.n.m., 17 nov. 1999 (fl., fr.), E. Melo et al. 3148 (HUEFS, UEC); Muniz Ferreira, fazenda Sete Brejos, córrego sob a ponte, $13^{\circ} 01^{\prime} \mathrm{S}, 39^{\circ} 07^{\prime} \mathrm{W}, 5$ maio 2015 (fr.), W.O. Fonseca 125 (HURB); Muritiba, Lagoa da Pedreira, estrada de Muritiba, $1 \mathrm{~km}$ depois do Portal da entrada, 12 $36^{\circ} \mathrm{S}$, 3900'W, 182 m s.n.m., 12 nov. 2014 (fl., fr.), L.Y.S. Aona 3603 (HURB); Nazaré, N-3 - lago da fazenda, brejo, 3 jun. 2015 (fr.), L.Y.S. Aona 4067 (HURB); Piatã, Cabrália, entre Piatã e Boninal, 1249'S, 4148'W, 997 m s.n.m., 17 nov. 2007 (fl., fr.), J.L. Ferreira et al. 220 (HUEFS); Piraí do Norte, BA-544, sentido Piraí do Norte-BA a Gandu, 13ํำ'S, 39²2'W, 6 maio 2014 (fl., fr.), R.S. Souza et al. 475 (HUESB, NY*); Piritiba, fazenda Guanabara,

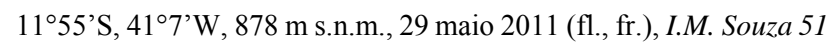
(HUEFS); Ribeira do Pombal, fazenda Salgadinho, $8 \mathrm{~km} \mathrm{~S} \mathrm{da}$

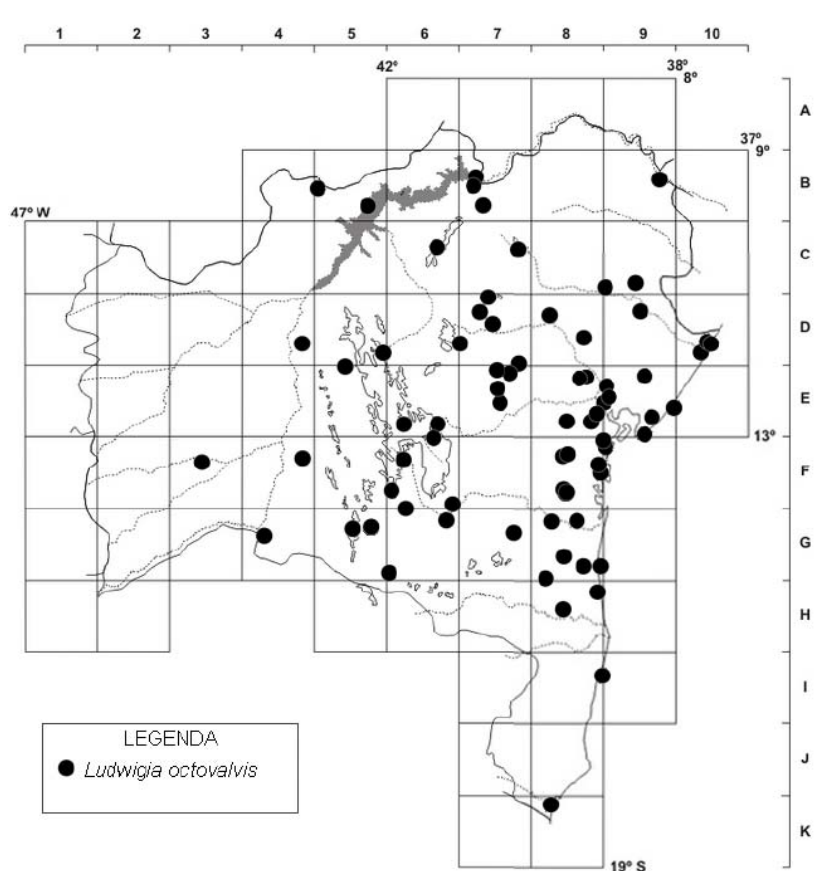

Figura 12. Mapa de distribuição geográfica de Ludwigia octovalvis no estado da Bahia.

cidade, BR-110, 1050’S, 38³3’W, 1 mar. 1984 (fl., fr.), L.R. Noblick 2955 (CEPEC, HUEFS, SP, UEC); Rio de Contas, às margens do rio Brumado, próximo a ponte, $13^{\circ} 58^{\prime} \mathrm{S}, 41^{\circ} 81$ ' $\mathrm{W}, 1.037$ m s.n.m., 20 ago. 2016 (fr.), N.X.M. Sousa 202 (HURB); Salvador, Dunas de Itapuã, $12^{\circ} 56^{\prime} \mathrm{S}, 38^{\circ} 21^{\prime} \mathrm{W}, 10$ fev. 1980, (fl., fr.), L.R. Noblick 1660 (ALCB, CEPEC, HUEFS); Santo Amaro, lago em direção a Salvador, 29 mar. 2011 (fl., fr.), L.Y.S. Aona et al. 1442 (HURB); Santo Antônio de Jesus, córrego em estrada vicinal, BR101, lado esquerdo, sentido Teolândia, $13^{\circ} 00^{\prime} \mathrm{S}, 39^{\circ} 15^{\prime} \mathrm{W}, 29$ jan. 2015 (fl., fr.), N.X.M. Sousa et al.111 (HURB); Sento Sé, Parque Nacional Boqueirão da Onça, Brejo da Martinha, 09 $52^{\prime}$ 'S, $41^{\circ} 17^{\prime} \mathrm{W}$, 472 m s.n.m., 22 jul. 2011 (fl., fr.), V.M. Cotarelli et al. 986 (HVASF); São Desidério, Manoel de Souza, $12^{\circ} 30^{\prime} \mathrm{S}, 45^{\circ} 05^{\prime} \mathrm{W}, 594$ m s.n.m., 21 jul. 2007 (fl., fr.), A. Cotrim et al. 814 (HUEFS); Serra Dourada, $5 \mathrm{~km}$ ao $\mathrm{N}$ de Tabocas, $10 \mathrm{~km}$ ao NW de Serra Dourada, Chapadão Ocidental da Bahia, $12^{\circ} 39^{\prime} \mathrm{S}, 4^{\circ} 02^{\prime} \mathrm{W}, 500$ m s.n.m., 1 maio 1980 (fl., fr.), R.M. Harley 21981 (CEPEC, K*, NY*, SPF, US*); Sobradinho, Baixo Médio São Francisco, lagoa próximo à Sobradinho, $09^{\circ} 28^{\prime}$ S, $40^{\circ} 49^{\prime} \mathrm{W}, 385$ m s.n.m., 22 set. 2009 (fl., fr.), F.S. Gomes et al. $269 b$ (HUEFS); Ubaitaba, nas margens sobre a ponte do Rio de Contas, 15 nov. 2019 (fl., fr.), N.X.M. Sousa et al. 757 (HURB); Umburanas, povoado Piemonte da Diamantina, Ponto

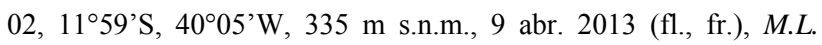
Guedes et al. 20624 (ALCB, HUEFS); Una, Reserva Biológica do Mico-Leão (IBAMA), entrada no Km 46 da BA-001, Ilhéus-Una, 1509'S, 3905'W, 21 abr. 1998 (fl., fr.), A.M. Amorim et al. 2379 (CEPEC); Valença, estrada para Orobó, com entrada no Km 3 da estrada Valença-BR-101, 7 fev. 1983 (fl., fr.), A.M. Carvalho et al. 1520 (CEPEC, HRB); Varzedo, 16 abr. 2015 (fl., fr.), N.X.M. Sousa et al. 114 (HURB); Vera Cruz, Ilha de Itaparica, Catu, 1306'S, $38^{\circ} 47^{\prime} \mathrm{W}, 24$ mar. 2010 (fl., fr.), L.Y.S. Aona et al. 1252b (HURB); Wenceslau Guimarães, assentamento Oziel Alves, 13³7'S, $39^{\circ} 37^{`}$ W, 8 jun. 2018 (fr.), N.X.M. Sousa et al. 318 (HURB).

Para comparação com as espécies mais semelhantes, veja os comentários em Ludwigia affinis e L. octovalvis. 


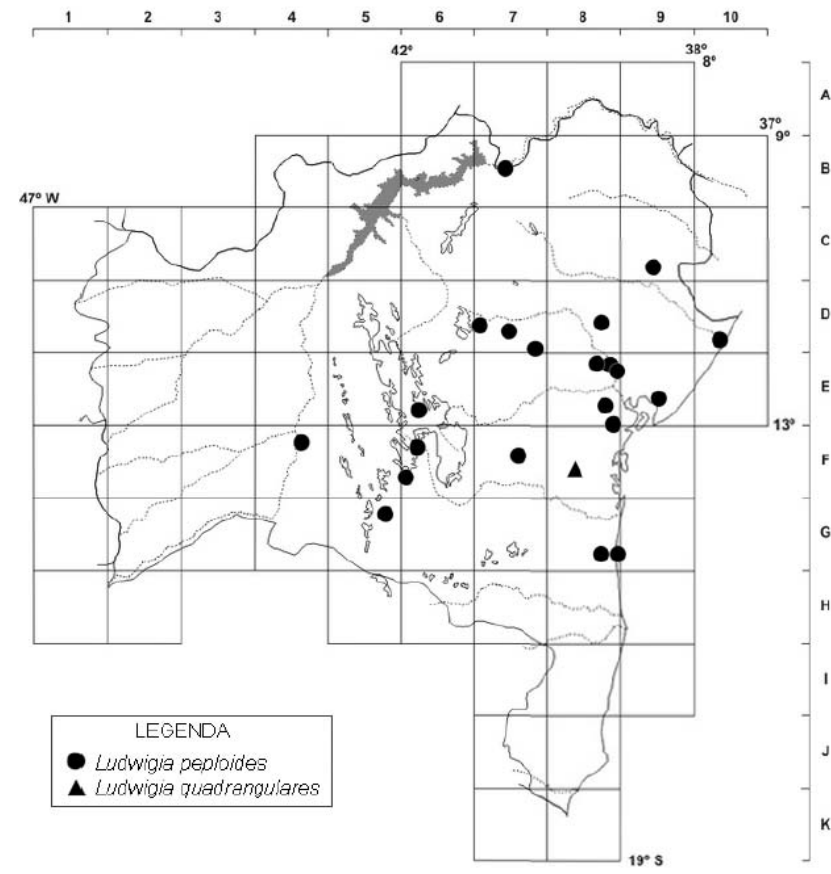

Figura 13. Mapa de distribuição geográfica de Ludwigia peploides e L. quadrangularis no estado da Bahia.

2.19. Ludwigia quadrangularis (Micheli) H.Hara, J. Jap. Bot. 28: 294. 1953.

Figuras 1CC, DD e 13; Munz (1947: fig. 31).

Subarbustos, levemente escandentes, anuais, 0,9-2 $\mathrm{m}$ alt.; caules ramificados, pubérulos, ramos densamente pubérulos e esbranquiçados nas extremidades. Folhas com lâmina 1,6-6,5 × 1-2,9 cm, face adaxial verde a verde brilhante, esparsamente pubérula a glabra, a abaxial verde, glabra, com a nervura central pubérula, oval e com extremidades assimétricas, raramente agudas, ou orbicular, com ápice agudo e base arredondada, coriácea; pecíolo $2-12 \mathrm{~mm}$ compr.; estípula inconspícua. Flores 4-meras, $1,4-1,8 \mathrm{~cm}$ compr.; sépalas 9-13 × 3-4,5 mm, verdes em ambas as faces, a adaxial esparsamente pubérula a glabra, a abaxial glabra, lanceoladas, ápice acuminado; pétalas $1,2-1,6 \mathrm{~cm} \times 4-5 \mathrm{~mm}$, oblongo-ovaladas, ápice arredondado a obtuso; estames desiguais, filetes e anteras eretos; nectário convexo, ápice plano; estigma capitado. Cápsulas 1,9-2,4 $\mathrm{cm} \times 3-4 \mathrm{~mm}$, verdes, 4angulares, subcilíndricas, pubérulas a glabrescentes; pedicelo 19-22 $\mathrm{mm}$ compr.; bractéola ca. $5 \mathrm{~mm}$ compr., na base dos frutos. Sementes ca. $6 \times 3 \mathrm{~mm}$, amareloacastanhadas, oblongo-ovoides; rafe proeminente, comprimento igual ao das sementes.

Endêmica do Brasil, no domínio fitogeográfico da Mata Atlântica, nos estados de Minas Gerais, Paraná, Rio de Janeiro e Santa Catarina, sendo este o primeiro registro para a Bahia (Zeferino et al. 2020). F8: floresta ombrófila densa, em vegetação de mata de encosta, nas margens de córrego, riacho, em solo argilo-arenoso. Apesar de buscas na região de Wenceslau Guimarães (Figura 13), não foram encontrados exemplares de $L$. quadrangularis. Coletada com flor e fruto em agosto.

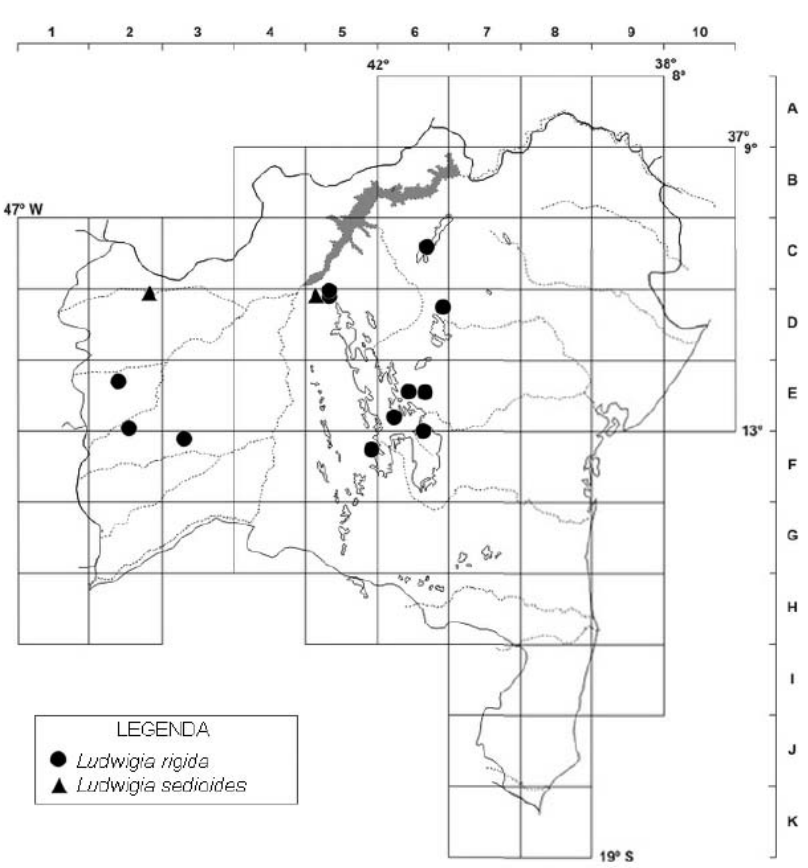

Figura 14. Mapa de distribuição geográfica de Ludwigia rigida e $L$. sedoides no estado da Bahia.

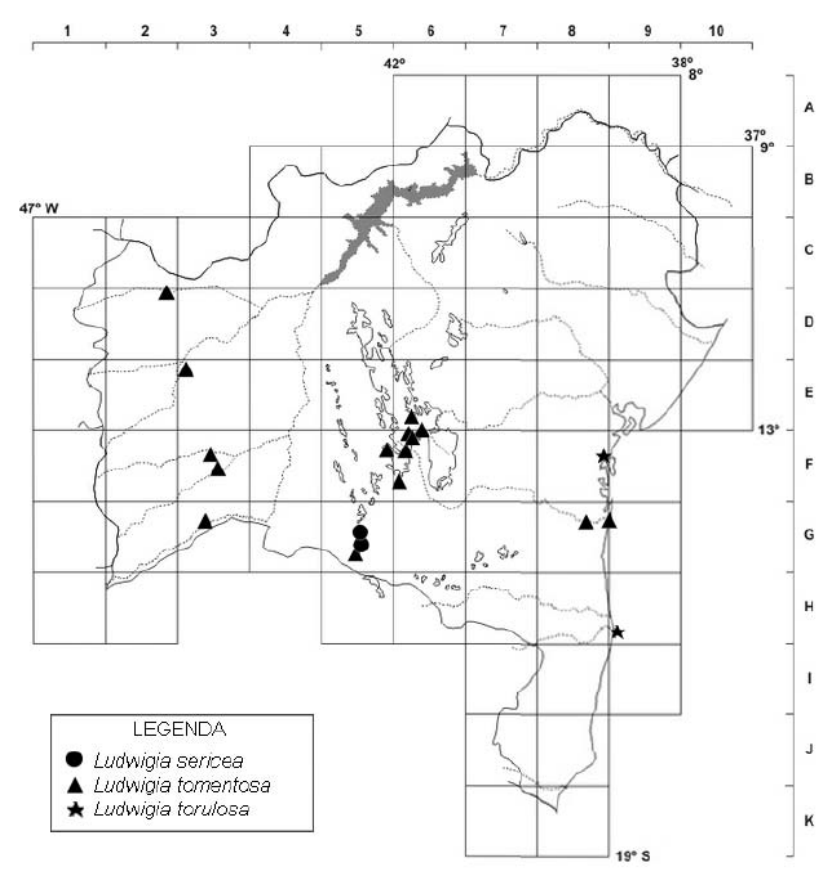

Figura 15: Mapa de distribuição geográfica de Ludwigia sericea, $L$. tomentosa e L. torulosa no estado da Bahia.

Material selecionado - Wenceslau Guimarães, assentamento Oziel Alves, 13³7'S, 39³7'W, 13 ago. 2001 (fl., fr.), L.J. Alves et al. 419 (ALCB).

Material adicional selecionado - BRASIL. RIO DE JANEIRO: Silva Jardim, Reserva Biológica de Poço das Antas, margens do rio S. João, entre a BR-101 e a ponte da linha férrea, $22^{\circ} 30^{\prime}$ 'S, $42^{\circ} 15^{\prime} \mathrm{W}, 30$ nov. 1992 (fl., fr.), M. Peron et al. 954 (CEPEC, SPF). SÃO PAULO: Barra do Turvo, Parque Estadual

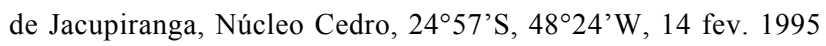
(fl., fr.), H.F. Leitão-Filho et al. 33524 (SPF). 
Ludwigia quadrangularis possui as folhas mais velhas ovais, com extremidades assimétricas, raro agudas, e as mais jovens orbiculares com ápice agudo e base arredondada. Já a face adaxial é verde a verde brilhante, esparsamente pubérula a glabra, e a face abaxial verde, glabra, com a nervura central proeminente e pubérula. Apresenta estigmas com cerca de 2,7 mm compr. e frutos visivelmente marcados pelas sementes envolvidas pelo endocarpo (Figura 1CC, DD).

\section{AgRADECIMENTO}

Este estudo faz parte da dissertação do curso de Mestrado em Recursos Genéticos Vegetais da Universidade Federal do Recôncavo da Bahia (PPGRGV/UFRB). Os autores agradecem aos curadores dos herbários ALCB, BRBA, CEPEC, ESA, HRB, HUEFS, HUESB, HUNEB, HURB, HVASF, IAC, MAC, SP, SPF, UEC, UESC, PEUFR; ao Dr. L. Marinho (UFMA) e ao Dr. E.H. Souza (UFRB) pela confecção dos mapas; à G.V. Fonseca (UFRB) pela foto concedida; à toda equipe do HURB pelo apoio e ajuda no trabalho de coleta e herborização e ao Programa de Pós-Graduação PPG-RGV/UFRB. NXMS agradece à FAPESB pela bolsa concedida (OL0175/2018) e ao PROCAD (88881.068513/2014-01) por permitir visitar os herbários ESA, SP, SPF e UEC. LYSA agradece aos financiamentos da FAPESB e do CNPq (APP113/2009 e 482085/2009-6, respectivamente).

\section{REFERÊNCIAS}

APG IV. 2016. An update of the Angiosperm Phylogeny Group classification for the orders and families of flowering plants: APG IV. Botanical Journal of the Linnean Society 181: 1-20.

Barroso, C.M.; Klein, G.N.; Barroso, I.B.I.; Franke, L.B. \& Delwing, A.B. 2007. Considerações sobre a propagação e o uso ornamental de plantas raras ou ameaçadas de extinção no Rio Grande do Sul, Brasil. Revista Brasileira de Horticultura Ornamental 13: 91-94.

Berry, P.E. 1982. The systematics and evolution of Fuchsia section Fuchsia (Onagraceae). Annals of the Missouri Botanical Garden 69: 1-198.

Berry, P.E. 1989. A systematic revision of Fuchsia section Quelusia (Onagraceae). Annals of the Missouri Botanical Garden 76: 532 584.

Berry, P.E.; Hahn, W.J.; Sytsma, K.J.; Hall, J.C. \& Mast, A. 2004. Phylogenetic relationships and biogeography of Fuchsia (Onagraceae) based on noncoding nuclear and chloroplast DNA data. American Journal of Botany 91: 601-614.

Castells A.R.C.; Ormond W.T.; Pinheiro M.C.B. \& Silva M.T.A. 1979. Estudo dos hidatódios e sua importância no complexo Ludwigia L. (Onagraceae). Arquivos do Jardim Botânico do Rio de Janeiro 23: 6-8.
Conti, E.; Litt, A. \& Sytsma, K. J. 1996. Circumscription of Myrtales and their relationships to other rosids: evidence from rbcL sequence data. American Journal of Botany 83: 221-233.

Conti, E.; Litt, A.; Wilson, P.G.; Graham, S.A.; Briggs, B.G.; Johnson, L.A.S. \& Sytsma, K.J. 1997. Interfamilial relationships in Myrtales: molecular phylogeny and patterns of morphological evolution. Systematic Botany 22: 629-647.

Cumana Campos, L. J. (2010). Clave para especies de Ludwigia L. (Onagraceae) de la región nor-oriental e insular de Venezuela depositadas en el herbario IRBR. Acta Botánica Venezuelica 33(2): 299-327.

Eyde, R.H. 1977. Reproductive structures and evolution in Ludwigia (Onagraceae). I. Androecium, placentation, merism. Annals of the Missouri Botanical Garden 64: 644-655.

Eyde, R.H. 1978. Reproductive structures and evolution in Ludwigia (Onagraceae). II. Fruit and seed. Annals of the Missouri Botanical Garden 66: 656-675.

Eyde, R.H. 1981. Reproductive structures and evolution in Ludwigia (Onagraceae). III. Vasculature, nectaries, conclusions. Annals of the Missouri Botanical Garden 68: 470-503.

Hickey, M. \& King, C. 2004. The Cambridge Illustrated Glossary of Botanical Terms. Cambridge University Press, Cambridge.

Hoch, P.C.; Crisci, J.V.; Tobe, H. \& P.E. Berry. 1993. A cladistic analysis of the plant family Onagraceae. Systematic Botany 18: $31-47$.

Hoch. P.C.; Wagner, W.L. \& Raven, P.H. 2015. The correct name for a section of Ludwigia L. (Onagraceae). PhytoKeys 50: 31-34.

INCT- Herbário Virtual da Flora e dos Fungos. Disponível em: $<$ http://inct.splink.org.br/ >. Acesso em: 30 jan. 2021.

Levin, R.A.; Wagner, W.L.; Hoch, P.C.; Nepokroeff, M.; Pires, J.C.; Zimmer, E.A. \& Sytsma, K.J. 2003. Family level relationships of Onagraceae based on chloroplast rbcL and ndhF data. American Journal of Botany 90: 107-115.

Levin, R.A.; Wagner, W.L.; Hoch, P.C.; Hahn, W.J.; Rodriguez, A.; Baum, D.A.; Katinas, L.; Zimmer, E.A. \& Sytsma, K.J. 2004. Paraphyly in tribe Onagreae: insights into phylogenetic relationships of Onagraceae based on nuclear and chloroplast sequence data. Systematic Botany 29: 147-164.

Liu, S.H.; Hoch P.C.; Diazgranados, M.; Raven, P.H. \& Barber, J.C. 2017. Multi-locus phylogeny of Ludwigia (Onagraceae): insights on infra-generic relationships and the current classification of the genus. Taxon 66: 1112-1127.

Lovo, J. \& Zappi, D.C. 2018. Flora das cangas da Serra dos Carajás, Pará, Brasil: Onagraceae. Rodriguésia 69: 157-164.

Munz, P.A. 1947. Onagraceae. In: F.C. Hoehne (ed.), Flora Brasílica, Fasc. 9, Vol. XLI. Instituto de Botânica, São Paulo.

Radford, A.E.; Dickson, W.C.; Massey, J.R. \& Bell, C.R. 1974. Vascular Plants Systematics. Harper \& Row, New York.

Ramamoorthy, T.P. \& Zardini, E.M. 1987. The systematics and evolution of Ludwigia sect. Myrtocarpus sensu lato (Onagraceae). Monographs in Systematic Botany 19: 1-120.

Raven, P.H. 1963. The Old World species of Ludwigia (including Jussiaea), with a synopsis of the genus (Onagraceae). Reinwardtia 6: 327-427.

Raven, P.H. 1988. Onagraceae as a model of plant evolution. In: L.D. Gottlieb \& S.K. Jain (eds), Plant Evolutionary Biology. Springer, Dordrecht, p. 85-107. 
Raven, P.H. \& Tai, W. 1979. Observations of chromosomes in Ludwigia (Onagraceae). Annals of the Mssouri Botanical Garden 66: 862-879.

Reflora, Herbário Virtual 2020. Onagraceae. In: Jardim Botânico do Rio de Janeiro. Disponível em: <http://floradobrasil.jbrj.gov.br/ reflora/floradobrasil/FB4071>. Acesso em: 13 jan. 2021.

Rodrigues, S.; Scremin-Dias, E.; Medeiros, S.C.H. \& Souza, M.C. 2007. Alterações estruturais do caule e da folha de Ludwigia inclinata (L.f.) M. Gómez, desenvolvidos emersos e submersos. Revista Brasileira de Biociências 5: 174-176.

Skvarla, J.J.; Raven, P.H. \& Praglowski, J. 1975. The evolution of pollen tetrads in Onagraceae. American Journal of Botany 62: 6-35.

Sousa, N.X.M.; Vieira, A.O.S.; Costa, G.M. \& Aona, L.Y.S. 2019. Caracteres importantes na identificação de espécies de Ludwigia (Onagraceae) ocorrentes no Recôncavo da Bahia, Brasil. Rodriguésia 70: 1-13.

Souza, V.C. \& Lorenzi, H. 2019. Botânica Sistemática: guia ilustrado para identificação das famílias de Fanerógamas nativas e exóticas no Brasil, baseado em APG IV. 4 ed. Instituto Plantarum, Nova Odessa.

Sytsma, K.J. \& Smith, J.F. 1992. Molecular systematics of Onagraceae: examples from Clarkia and Fuchsia. In: P.S. Soltis, D.E. Soltis \& J.J. Doyle (eds), Molecular Systematics of Plants. Chapman and Hall, New York, p. 295-323.

Sytsma, K.J.; Smith, J.F. \& Berry, P.E. 1991. The use of chloroplast DNA to assess biogeography and evolution of morphology, breeding systems, and flavonoids in Fuchsia section Skinnera (Onagraceae). Systematic Botany 16: 257269.

Thiers, B. 2020 [continuamente atualizado]. Index Herbariorum: a global directory of public herbaria and associated staff. New York Botanical Garden. Disponível em: http://sweetgum.nybg. org/science/ih/. Acesso em: 30 jan. 2020.

Wagner, W.L.; Hoch, P.C. \& Raven, P.H. 2007. Revised classification of the Onagraceae. Systematic Botany Monographs 83: $1-240$.

Zardini, E.M. \& Raven, P.H. 1992. A new section of Ludwigia (Onagraceae) with a key to the sections of the genus. Systematic Botany 17: 481-485.

Zardini, E. M. \& Raven, P. H. 1997. Onagraceae. In: J.A. Rizzo (coord.), Flora dos Estados de Goiás e Tocantins, Vol. 20, Coleção Rizzo. Ed. UFG, Goiânia.

Zardini, E.M. \& Raven, P.H. 2003. Onagraceae. In: J.A. Steyermark, P.E. Berry, K. Yatskievych \& B.K. Holtz (eds), Flora of the Venezuelan Guayana. MyrtaceaePlumbaginaceae, Vol. 7. Missouri Botanical Garden Press, St. Louis, p. 188-197.

Zeferino, L.C.; Fernandes, F.; Echternacht, L. \& Heiden, G. 2021. Onagraceae. In: Flora do Brasil 2020 em construção. Jardim Botânico do Rio de Janeiro. Disponível em: $<$ http://floradobrasil.jbrj.gov.br/reflora/floradobrasil/FB177>. Acesso em: 13 jan. 2021.

\section{LiSTA DE EXSICATAS}

Adorno, H. s.n. HST 17662 (2.7); Alcântara, J.A.C. 4 (2.7); Almeida, A.M.M. s.n. ALCB 67131, CEPEC 107439 (2.7); Almeida, G.O. 176a (2.13); Alunos da Ecologia Vegetal 1996.2 s.n. HUNEB 35 (2.7), Alunos de Leclécia s.n. ALCB 17971 (2.7); Alves, L.J. 419 (2.19); Amorim, A.M. 2098 (2.7), 3596 (1.1), 4312 (2.7), 5806 (1.1), 6801, 8028, (2.7); Anjos, B.A. 29 (2.11); Aona, L.Y.S. 1022 (2.18), 1048 (2.5), 1049 (2.7), 1075, 1103 (2.18), 1109 (2.1), 1136, 1180, 1201a, 1206, 1247b, 1221c, 1252b (2.18), 1303, 1355 (2.7), 1373 (2.15), 1378 (2.7), 1424, 1442 (2.18), 1465, 1485a (2.7), 1485b (2.18), 1507 (2.15), 1522 (2.7), 1548 (2.5), 1549 (2.7), 1569 (2.15), 3231 (2.5), 3232 (2.7), 3246a (2.1), 3246b (2.15), 3250 (2.7), 3596 (2.1 HURB, 2.15 HUEFS), 3603 (2.18), 3604 (2.7), 3625 (2.1), 3626 (2.7), 3880a (2.15), 3880b (2.7), 4067 (2.18), 4119 (2.7), 4120 (2.1), 4173, 4193,4211 (2.7), 4247 (2.15), 4248, 4327 (2.7), 4328 (2.15), 4868c, 4967 (2.7), 4968 (2.1), 4970 (2.9), 4971 (2.7), 5360 (2.15), 5374 (2.7); Araújo, D.A. 16 (2.18); Araújo, F.S. 716 (2.7); Araújo, G. 385 (2.10); Árbocz, G.F. 4277 (2.17); Bacelar, T.G. 69 (2.7); Barreto, T.R. 4 (2.7); Bautista, H.P. 1047a (2.18 CEPEC), 1047b (2.7 CEPEC, HRB, HUEFS), 1482 (2.2), 1365 (2.7), 2477 (2.15), 2478 (2.18); 3315 (2.13), 3300 (2.11), 3695 (2.10); Batista, L.P. $47 / 92$ (2.11); Belém, R. P. 533 (2.7), 692 (2.18); Blanchet, J.S. 3147 (2.3); Borges, R.A.X. 385 (1.1); Braga, N.M.P. 84 (2.18); Campos, G.L. 154 (2.7); Cardoso, D. 76 (2.7), 1002 (2.18), 1353 (2.15), 2085 (2.10), 2146 (1.1); Carneiro-Torres, D.S. 258 (2.18), 356 (2.15); Carvalho, A. J. 74 (2.18); Carvalho, A.M. 345 (2.18), 4072,6606 (2.13); Carvalho, C.A.L. 96 (2.18); Carvalho, I.M.O. 01, 10 (2.18), 28 (2.7); Carvalho-Sobrinho, J.G. 717 (2.11); Casaes, M.P. 51 (2.15); Chagas-Mota 6652 (2.5); Chaves, M.M.M. 11 (2.1); Conceição, A.A. 2308, 2402, 2403 (2.7); Conceição, A.S. 753 (2.11); Conceição, S.F. 806, 857, 916 (2.7); Coradin, L. 5974 (2.7); Correia, C. 370 (2.15); Costa, C.B.N. \& Costa, J. 1376 (2.18); Costa, G. 365 (2.15), 647 (2.7 UEC, 2.18 HURB), 728 (2.7), 831 (2.1), 834, 1041, 1159, 1199 (2.7), 1206 (2.15), 1207 (2.18), 1220 (2.5), 1232 (2.1), $1233(2.18), 1381,1401$ (2.7), 1876, 1944 (2.1), 1953, 2109 (2.7), 2450 (2.11), 2632 (2.5), 2760, (2.1), 2761, 2906 (2.7), 3230 (2.15), 3369 (2.11), 3471 (2.1), 3472 , 3654 (2.7), 11232 (2.1); Cotarelli, V.M. 1511 (2.18); Cotrim, A. 814 (2.18), 504 (2.8), 505, 1093 (2.10), 1122 (2.8); Cotias, A.L. s.n. ALCB 81021 (2.7); Esteves, F. 466 (2.18), 472 (2.18), s.n. HUEFS 179026 (2.1); Faria, A.D. 96150 (2.14); Faria, G. A. 175 (2.7); Farias, K.A. 1 (2.7); Felix, L.P. 8771 (2.11); Fernandes, D.S. 67 (2.11); Ferreira, G.V. 173 (2.1); Ferreira, J.C.D.A. 67 (2.7), 263 (2.11); Ferreira, J.L. 01 (2.7), 3 (2.1), 30 (2.5), 32 (2.18), 110 (2.18), 141 (2.18), 02 (2.15), 177 (2.7); Ferreira, J.V.A. 61 (2.15); Fiaschi, P. 2465 (2.11); Filho, O.S. 23 (2.7); Fonseca, G.V. 173 (2.1), 175 (2.5), 398 (2.6), 407 (2.7); Fonseca, M.R. 42 (2.18); Fonseca, W.O. 125 (2.18), 126 (2.7), 144 (2.1), 557, 589 (2.7), 615 (2.5), 616 (2.7); França, F. 1757, 1761 (2.5), 1764 (2.7), 1766 (2.1), 1773 (2.7), 1890 (2.7), 2009 (2.5), 2027 (2.18), 2360 (2.15), 2361 (2.7), 3102 (2.18), 3257 (2.1), 3609 (2.10), 3611,3659 (2.13), 5084 (2.7), 5608 (2.7), 5627 (2.11), 6006 (2.7); Funch, L.S., FCD 102 (2.7); Funch, R. 20 (2.11); Ganev, W. 390 (2.15), 391 (2.5), 1855 (2.10), 2372 (2.7); Gomes, D.J. 15 (2.7); Gomes, F.S. 269 a (2.7 ALCB, HUEFS), 1311 (2.7), 1220 (2.15); Gonçalves, L.M.C. 70 (2.7); Giulietti, A.M. PCD 268 (2.18), 1561 (2.13), 1770 (2.15), 1907,1912 , 2304, 2467 (2.7), 2678 (2.18), 2681 (2.7 HUEFS, 2.18 CEPEC, HRB), 4051 (2.13); Grupo Pedra do Cavalo, 68 (2.15), 73 (2.7), 263,264 (2.15), 277 (2.7), 904 (2.5); Guedes, M.L. 760 (2.18), 792 (2.10), 2848 (2.18), 2953, 5074 (2.15), 7329, 7409 (2.7), 7825 (2.4), 11059 (2.7), 11399, 12110 (2.15), 12801 (2.13), 13538 (2.18), 13600, 13601, 13603 (2.7), 13632, 13639, 13771 (2.13), 14138 (2.4), 15102 (2.7), 15924 
(2.13), 16747 (2.12), 17126 (2.13), 17513 (2.1), 18042, 18171 (2.7), 18187, 20191 (2.5), 20614 (2.15), 21574, 21608 (2.18), 21735,21789 , 22580, 22675 (2.13), 23117, 24602 (2.7), 24623 (2.15), 24799 (2.1), 30716 (2.7), 31046 (2.18), 31797 (2.1), s.n. ALCB 20454 (2.7), s.n. ALCB 76764 (2.4); Hage, J.L. 614 (2.15), 699 (2.7), 915 (2.15), 1680, 1791 (2.7), 1805, 1928 (2.15), 1929 (2.7), 1982 (2.15), 1983 (2.7), 2343 (2.11); Harley, R.M. 6978, 15485 (2.7), 15766 (2.16), 16276 (2.4), 16280 (2.15), 16941, 17147 (2.7), 18798 (2.16), 19392 (2.7), $19633,19826,19829$ (2.13), 20033, 20034, 20036 (2.7), 20109 (2.16), 21465 (2.4), 21618 (2.9 SPF, UEC, 2.13 CEPEC, US*), 21641 (2.13 K*, NY*, SPF, US*, 2.17 CEPEC), 21691, $21691 \mathrm{a}$ (2.8), 21691A (2.18 SP, SPF) 21846 (2.13), 21848 (2.18), 21947 (2.11), 21982 (2.15), 22155 (2.7), 25624 (2.11), 25625 (2.13), 54030 (2.11), 54048 (2.7), 54665 (2.11); Hatschbach, G. 46391 (2.15), 47868 (2.7), 47596 (2.14), 48009 (2.16), 49502 (2.10), 56691 (2.18); Hind, D.J.N. 50453 (2.7), 50478 (2.5); Irwin, H.S. 31647 (2.13); Jardim, J.G. 887 (2.8), 3384 (2.2), 3385 (2.4), 3417 (2.7), 3713 (2.13); Jesus, J.A. 340 (2.7); Jesus, L.S. 36 (2.7); Jesus, N.G. 1282, 2268 (2.7), 2293 (2.18), 2301a (2.7), 2301b (2.18); Jesus, R.J.A. 14, 41 (2.7); Jost, T. 238 (2.15); Leitão Filho, H.F. \& Aranha, C. 190 (2.13); Leitão-Filho, H.F. 33524 (2.19); Leite, K.R.B. 13 (2.11), 292 , 445, 456 (2.5), 458, 464, 466, 472 (2.18); Lindeman, J. C. 941 (2.6); Lima, A. 56-2494 (2.5); Lima, C.T. 222 (2.7), 322 (2.4); Lima, J.C.A. 233 (2.7); Lopes, E.B. 64 (2.7); Lopes, D.M. s.n. HURB 2166 (2.18); Lopes, M.M.M. 1267 (1.1); Lordêlo, R. P. 58-6 (2.5); Martins, C.T.V.D. 261 (2.11); Martins, M.L.L. 1552 (2.7); Mascarenhas, A.A.S. 241 (2.11); Mayo, S.J. 1076 (2.13); Melo, E. 1720 (2.1), 1738 (2.5), 1740 (2.7), 1759 (2.1), 1806 (2.18), 1808 (2.1 MBM*, 2.15 CEPEC, HUEFS, SP), 1810a (2.1), 1817 (2.5), 1997 (2.7), 1999 (2.15), 2019 (2.18), 2021 (2.5), 2077 (2.15), 2118 (2.5), 2739 (2.3), 2740 (2.11), 3991(2.18), 4015 (2.10), 4665 (2.7), 4710 (2.15), 5084, 5173,5285 (2.7), 5363 (2.10), 6825 (2.1), 6839 (2.7), 7053 (2.15), 11991 (2.16), 12304, 13312 (2.11), 13284 (2.15), 13287 (2.7), 13495 (2.11); Melo, P.A. 87 , 108 (2.7); Mendes, M.S. 546 (2.1), 547 (2.7); Menezes, C.M. 140 (2.7), 274 (2.16); Miranda, A.M. 3996, 6778 (2.7); Moreira, D.M. 365 (2.1); Moreira, R.S. 369 (2.7); Mori, S.A. 9864, 10098, 10438 (2.7), 10462 (2.10), 11606 (2.15), 11605 (2.7), 12248, 12322 (2.13); Moruz, C.V.A. 25 (2.7); Moura E.O. 26619113.1, 77713833.5 (2.10); Nascimento, J.G. 20 (2.7); Navarro, F. s.n. ALCB 23068 (2.15); Neri, J. 59 (2.13); Noblik, L.R. 1728 (2.5), 1872 (2.15), 1879 (2.5), 1881 (2.18), 1959 (2.7), 1968 (2.1), 2276, 2309, 2543 (2.7), 2956 (2.5), 3019 (2.7), 3653 (2.15), 4137 (2.5), 4141 (2.7), 4185 (2.15); Nunes, T.S. 73 (2.13), 95 (2.10), 325 (2.7 HUNEB, 2.18 HUEFS, UEC), 469 (2.7); Oliveira, A.A. 204 (2.18), 210 (2.13); Oliveira, A.N. 42 (2.7), s.n. HURB 17784 (2.18), s.n. HURB 17787 (2.7); Oliveira, E.L.P.G. 356, 730 (2.7); Oliveira, J.F.C. 75 (2.7); Oliveira, M. 3050 (2.11), 4513 (2.5); Oliveira, R.P. 498 (2.3), 629 (2.10); Oliveira, T.S. 122 (2.18); Oliveira, V.F. 8 (2.15); Oliveira-Rebouças, P. 48 (2.18); Orlandi, R.P. 523 (2.15); Paixão, J.L. 1598 (2.7); Paraguassu, L. 15 (2.7), 27 (2.18); Pastore, J.F.B. 3731 (2.7); Paula-Souza, J. 9819 (2.1 SPF, 2.7 IAC), 9824 (2.1), 9825 (2.7); Prata, A.P. 1998 (2.4); Perdiz, R.o. 718 (1.1); Pereira C.M.S.S. 4 (2.4); Peron, M. 954 (2.19); Pinheiro, R.S. 1890 (2.1); Pinto, G.P.P. 134, 234 (2.7) s.n. ALCB 9043, s.n. ALCB 9248, IAC 15455 (2.1); Pires, M.J. 1442 (2.6); Pivari, M.O.D. 74 (2.6); Popovkin, A.V. 5 (2.7); Queiroz, E.P. 653, 1506, 716 (2.7), 3078 (2.10), 4695 (2.18); Queiroz, L.P. 721 (2.18), 5057 (2.13), 7812,9233 (2.7), 9659 (2.15), 9673 (2.1), 9888 (2.7), 13691 (2.11), 16685 (2.7); Ramamoorthy, T.P. 328 (2.10); Ramos, C.E. 327 (2.7); Reis, J.A. 37 (2.1); Ribeiro, T. 26 (2.5), 304 (2.13); Rigueira, D. 10 (2.7), s.n. ALCB 69067 (2.10); Rocha, E.A. 1038, 1091, 1724, 1725 (2.7); Rodrigues, M.O.S. 16 (2.7); Roque, N. 85, 2111 (2.7), 3167 (2.12), 4530 (2.5); Sá, C.P.O. 195 (2.10); Sant'Ana, S.C. 966 (2.18); Santana, D.L. 673 (2.4); Santos, E.B. 25 (2.5), 251 (2.13); Santos, S.M. 01 (2.7); Santos, T.A. s.n. HURB 17777 (2.7); Santos, T.S. 2401 (2.10), 2987 (2.6), 3686 (2.5); Sartori, A.L.B. 230 (2.7); Silva, E.A. 1, 35 (2.11); Silva, E.M. 19 (2.2), s.n. ALCB 98908 (2.4); Silva, F.B.L. 37 (2.7); Silva, J.S. (2.15); Silva, L.A.M. 3170, 3237 (2.7), 3328 (2.15), 3333 (2.7); Silva, L.S. 226 , 261 (2.7); Silva, M.E.B. 353 (2.2); Silva, M.M. 149 (2.7); Silva, M.P. 4 (2.7); Silva, T.R.S. 43 (2.13), 52 (2.7); Silva,T.T. 7, 122 (2.7); Siqueira, E.L. 928 (2.13); Siqueira Filho, J.A. 1702 (2.15), 1804 (2.18), 3176 (2.1); Stannard, B. 52722 (2.13); Sousa, M.P. 09, 34, 73 (2.7); Sousa, N.X.M. 7 (2.7), 8, 9, 10 (2.18), 11 (2.7), 12 (2.5), 13 (2.18), 14 (2.7), 15 (2.1), 21 (2.7), 29, 31 (2.7), 33 (2.1), 34 (2.7), 36 (2.15), 37 (2.1), 38 , 39 (2.7), 40 (2.18), 41, 42 (2.1), 43, 44, 45, 46 (2.7), 47 (2.1), 48 (2.18), 49 (2.7), 50 (2.15), 53 (2.1), 54 (2.7), 55 (2.18), 56 (2.1), 57 (2.18), 58 (2.7), 62 (2.5), 71, 73 (2.13), 75 (2.7), 79 (2.18), 109 (2.1), $110(2.7), 111(2.18), 112(2.15), 113(2.7), 114(2.18), 117,125(2.15), 126$ (2.1), 141 (2.5), 142 (2.15), 143, 144 (2.1), 145, 147 (2.7), 153 (2.7), 154 (2.15), 155 (2.1), 157 (2.11), 166 (2.7), 167 (2.13), 171 (2.18), 176 , 190 (2.7), 194 (2.13), 196 (2.11), 198 (2.7), 201 (2.5), 202 (2.18), 204 (2.1), 205 (2.7), 206 (2.15), 229, 259, 273 (2.1.), 278 (2.5), 296 (2.7), 297 (2.1.), 298, 308 (2.7), 318 (2.18), 322 (2.15), 323 (2.1.), 327 (2.7), 328 (2.1.), 329 (2.15), 335 (2.7), 341, 347 (2.18), 386 (2.11), 391 (2.18), 464 (2.11), 465 (2.13), 476 (2.11), 491 (2.7), 494 (2.11), 500 (2.16), 501 (2.7), 502 (2.15), 503 (2.1), 504 (2.7), 505 (2.5), 506 (2.7), 507 (2.15), 508 (2.1), 509 (2.7), 516 (2.18), 538 (2.11), 543 (2.10), 556 (2.7), 559 (2.18), 562 (2.7), 565 (2.18), 570 (2.5), 571 (2.4), 577 (2.18), $581(2.5)$, 582 (2.7), 584 (2.1), 585 (2.15), 586 (2.7), 587 (2.15), 591 (2.13), 592 (2.12), 593 (2.14), 595 (2.5), 596,597 (2.9), 598 (2.7), 603 (2.8), 610 (2.13), 619 (2.5), 620 (2.7), 623 (2.15), 635 (2.1), 636 (2.15), 637 (2.7), 641 (2.15), 642 (2.7), 732 (2.13), 733 (2.7), 734 (2.13), 735,738 (2.1), 739 (2.7), 740 (2.18), 743 (2.15), 745 (2.1), 746 (2.7), 754, 757 (2.18), 759 (2.7), 761 (2.18); Sousa, T. 45 (2.7); Souza, C.O. 46 (2.7); Souza, L.D. s.n. HURB 17851 (2.15); Souza-Silva, R.F. 239 (2.13); Souza, V.C. 22818 (2.13), 26156 (2.7); Thomas, W.W. 9907 (2.10); Torres, R.B. 265 (2.16); van den Berg, C. 962 (2.7); Vasconcelos, T.N.C. 454 (2.7); Velanes, M.C. s.n. ALCB 21398 (2.7); Vieira, T. 21 (2.5), 22 (2.15), 93, 124 (2.10); Virgens, L.P. 9 (2.7); Walter, B. 466 (2.10); Wanderley, P.H.S. 120 (2.13); Xavier, A.B. 305 (2.7); Zardini, E. 2224 , 2225, 2226 (2.7), 2227 (2.13), 2229, 2230 (2.18), 2231 (2.7), 2232 (2.18), 2233 (2.7), 2234 (2.18), 2236 (2.7), 2238 (2.5), 2240 (2.7); Zappi, D.C. 1468 (2.17). 